Cochrane Database of Systematic Reviews

\title{
Cranberries for preventing urinary tract infections (Review)
}

Jepson RG, Williams G, Craig JC

Jepson RG, Williams G, Craig JC.

Cranberries for preventing urinary tract infections.

Cochrane Database of Systematic Reviews 2012, Issue 10. Art. No.: CD001321.

DOI: 10.1002/14651858.CD001321.pub5. 
TABLE OF CONTENTS

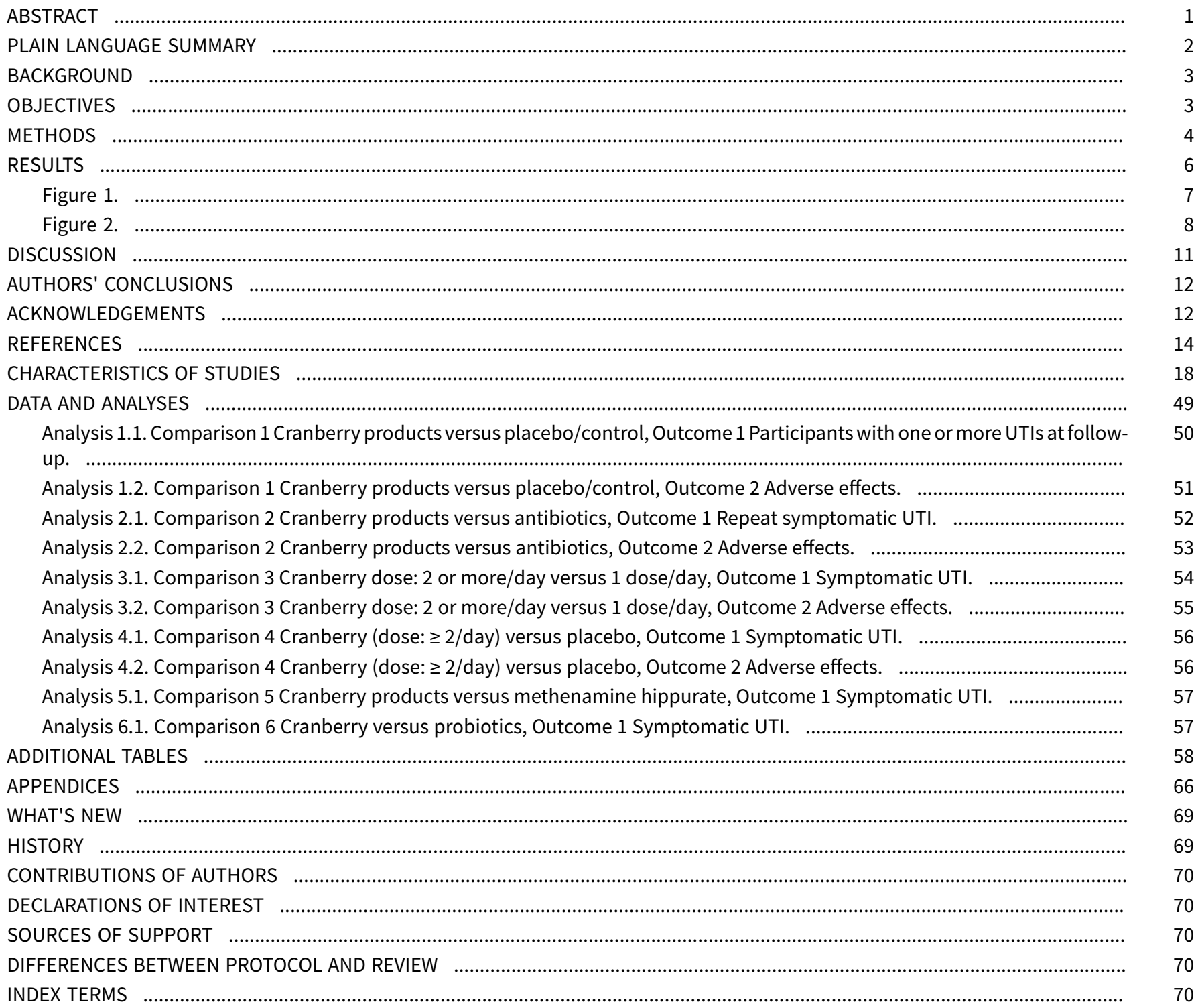


[Intervention Review]

\section{Cranberries for preventing urinary tract infections}

Ruth G Jepson ${ }^{1}$, Gabrielle Williams ${ }^{2}$, Jonathan C Craig 3

1Scottish Collaboration for Public Health Research and Policy (SCPHRP), Edinburgh, UK. ${ }^{2}$ Centre for Kidney Research, The Children's Hospital at Westmead, Westmead, Australia. ${ }^{3}$ Cochrane Renal Group, Centre for Kidney Research, The Children's Hospital at Westmead, Westmead, Australia

Contact: Ruth G Jepson, Scottish Collaboration for Public Health Research and Policy (SCPHRP), 20 West Richmond Street, Edinburgh, Scotland, EH8 9DX, UK. ruth.jepson@ed.ac.uk, ruth.jepson@scphrp.ac.uk.

Editorial group: Cochrane Kidney and Transplant Group.

Publication status and date: Edited (no change to conclusions), published in Issue 6, 2014.

Citation: Jepson RG, Williams G, Craig JC. Cranberries for preventing urinary tract infections. Cochrane Database of Systematic Reviews 2012, Issue 10. Art. No.: CD001321. DOI: 10.1002/14651858.CD001321.pub5.

Copyright @ 2014 The Cochrane Collaboration. Published by John Wiley \& Sons, Ltd.

\section{A B S T R A C T}

\section{Background}

Cranberries have been used widely for several decades for the prevention and treatment of urinary tract infections (UTIs). This is the third update of our review first published in 1998 and updated in 2004 and 2008.

\section{Objectives}

To assess the effectiveness of cranberry products in preventing UTIs in susceptible populations.

\section{Search methods}

We searched the Cochrane Renal Group's Specialised Register (4 June 2013) through contact with the Trials' Search Co-ordinator using search terms relevant to this review.We contacted companies involved with the promotion and distribution of cranberry preparations and checked reference lists of review articles and relevant studies.

Date of search: July 2012

\section{Selection criteria}

All randomised controlled trials (RCTs) or quasi-RCTs of cranberry products for the prevention of UTIs.

\section{Data collection and analysis}

Two authors independently assessed and extracted data. Information was collected on methods, participants, interventions and outcomes (incidence of symptomatic UTIs, positive culture results, side effects, adherence to therapy). Risk ratios (RR) were calculated where appropriate, otherwise a narrative synthesis was undertaken. Quality was assessed using the Cochrane risk of bias assessment tool.

\section{Main results}

This updated review includes a total of 24 studies (six cross-over studies, 11 parallel group studies with two arms; five with three arms, and two studies with a factorial design) with a total of 4473 participants. Ten studies were included in the 2008 update, and 14 studies have been added to this update. Thirteen studies (2380 participants) evaluated cranberry juice/concentrate; nine studies (1032 participants) evaluated cranberry tablets or capsules; one study compared cranberry juice and tablets; and one study compared cranberry capsules and tablets. The comparison/control arms were placebo, no treatment, water, methenamine hippurate, antibiotics, or lactobacillus. Eleven studies were not included in the meta-analyses because either the design was a cross-over study and data were not reported separately for the first phase, or there was a lack of relevant data. Data included in the meta-analyses showed that, compared with placebo, water or not treatment, cranberry products did not significantly reduce the occurrence of symptomatic UTI overall (RR $0.86,95 \% \mathrm{Cl} 0.71$ to 1.04$)$ 
or for any the subgroups: women with recurrent UTIs (RR 0.74, 95\% Cl 0.42 to 1.31); older people (RR 0.75, $95 \%$ Cl 0.39 to 1.44 ); pregnant women (RR 1.04, 95\% Cl 0.97 to 1.17); children with recurrent UTI (RR $0.48,95 \% \mathrm{Cl} 0.19$ to 1.22); cancer patients (RR $1.1595 \% \mathrm{Cl} 0.75$ to 1.77); or people with neuropathic bladder or spinal injury (RR $0.95,95 \% \mathrm{Cl}: 0.75$ to 1.20$)$. Overall heterogeneity was moderate $\left(I^{2}=55 \%\right)$. The effectiveness of cranberry was not significantly different to antibiotics for women (RR $1.31,95 \% \mathrm{Cl} 0.85,2.02$ ) and children (RR $0.6995 \%$ $\mathrm{Cl} 0.32$ to 1.51). There was no significant difference between gastrointestinal adverse effects from cranberry product compared to those of placebo/no treatment (RR $0.83,95 \% \mathrm{Cl} 0.31$ to 2.27). Many studies reported low compliance and high withdrawal/dropout problems which they attributed to palatability/acceptability of the products, primarily the cranberry juice. Most studies of other cranberry products (tablets and capsules) did not report how much of the 'active' ingredient the product contained, and therefore the products may not have had enough potency to be effective.

\section{Authors' conclusions}

Prior to the current update it appeared there was some evidence that cranberry juice may decrease the number of symptomatic UTIS over a 12 month period, particularly for women with recurrent UTIs. The addition of 14 further studies suggests that cranberry juice is less effective than previously indicated. Although some of small studies demonstrated a small benefit for women with recurrent UTIs, there were no statistically significant differences when the results of a much larger study were included. Cranberry products were not significantly different to antibiotics for preventing UTIs in three small studies. Given the large number of dropouts/withdrawals from studies (mainly attributed to the acceptability of consuming cranberry products particularly juice, over long periods), and the evidence that the benefit for preventing UTI is small, cranberry juice cannot currently be recommended for the prevention of UTIs. Other preparations (such as powders) need to be quantified using standardised methods to ensure the potency, and contain enough of the 'active' ingredient, before being evaluated in clinical studies or recommended for use.

\section{PLAIN LANGUAGE SUMMARY}

\section{Cranberries for preventing urinary tract infections}

Cranberries (usually as cranberry juice) have been used to prevent urinary tract infections (UTIs). Cranberries contain a substance that can prevent bacteria from sticking on the walls of the bladder. This may help prevent bladder and other UTIs. This review identified 24 studies (4473 participants) comparing cranberry products with control or alternative treatments. There was a small trend towards fewer UTIs in people taking cranberry product compared to placebo or no treatment but this was not a significant finding. Many people in the studies stopped drinking the juice, suggesting it may not be an acceptable intervention. Cranberry juice does not appear to have a significant benefit in preventing UTIs and may be unacceptable to consume in the long term. Cranberry products (such as tablets or capsules) were also ineffective (although had the same effect as taking antibiotics), possibly due to lack of potency of the 'active ingredient'. 


\section{B A C K G R O U N D}

The term urinary tract infection (UTI) refers to the presence of a certain threshold number of bacteria in the urine (usually $>100,000 / \mathrm{mL}$ ). It consists of cystitis (bacteria in the bladder), urethral syndrome and pyelonephritis (infection of the kidneys). Lower UTIs involve the bladder, whereas upper UTIs also involve the kidneys (pyelonephritis). Bacterial cystitis (also called acute cystitis) can occur in men and women and the signs and symptoms include dysuria (pain on passing urine), frequency, cloudy urine, occasionally haematuria (blood in the urine), and is often associated with pyuria (urine white cell count greater than $10,000 / \mathrm{mL}$ ). Urethral syndrome (frequency and dysuria syndrome) is used to describe approximately $50 \%$ of women with these complaints who have either no bacterial growth or counts less than 100,000 colony-forming units $(\mathrm{cfu}) / \mathrm{mL}$ on repeated urine cultures. Pyelonephritis is thought to occur as a result of cystitis, particularly in the presence of transient (occasional) or persistent backflow of urine from the bladder into the ureters or kidney pelvis (vesicoureteric reflux). Signs and symptoms include flank pain or back pain, fever, chills with shaking, general ill feeling plus those symptoms of a lower UTI. Acute pyelonephritis can be severe in the elderly, in infants, and in people who are immunosuppressed (for example, those with cancer or AIDS). Although most people who present to the doctor or hospital have symptomatic UTIs, some can be asymptomatic and only those who are at high risk of developing further infections (pregnant women and the elderly) are considered to need treatment. Some people also have recurrent UTIs with an average of two to three episodes/year (Roberts 1979; Wong 1984). Children often present with a fever and non-specific symptoms such as lethargy (tiredness), vomiting or poor feeding.

UTIs are one of the most common medical conditions requiring outpatient treatment, and complications resulting from persistent and repeated infections necessitate well over one million hospital admissions annually in the USA (Patton 1991). Specific subpopulations are at increased risk of developing a UTI. These groups include infants, pregnant women, the elderly, patients with spinal cord injuries and/or catheters, patients with diabetes or multiple sclerosis, patients with acquired immunodeficiency disease syndrome/human immunodeficiency virus, and patients with underlying urologic abnormalities (Foxman 2002). Although UTIs can occur in both men and women, they are about 50 times more common in adult women than adult men. This may be because women have a shorter urethra that may allow bacteria to ascend more easily into the bladder. Symptomatic infection of the bladder (lower UTI) has been estimated to occur in up to $30 \%$ of women at some stage during their lives (Kelly 1977). The annual incidence of acute uncomplicated UTI is $7 \%$ for all ages of women peaking at 15-24 years and women older than 65 (Giesen 2010). Up to $25 \%$ of women who have a UTI are likely to have a reoccurrence within six months (Epp 2010). UTIs often occur in clusters with long periods (several months) where patients are symptom free (Stapleton 1997).

Most UTIs are thought to arise from the 'ascending' route of infection. The first step is colonisation of periurethral tissues with uropathogenic organisms, followed by the passage of bacteria through the urethra. Infection arises from bacterial proliferation (growth) within the otherwise sterile urinary tract. In children, UTI occurs more commonly in boys up to the age of 12 months, but overall occurs about three times more often in girls ( $1 \%$ to $3 \%$ in boys, 3\% to 7\% in girls) (Hellstrom 1991; Winberg 1974).

Cranberries (particularly in the form of cranberry juice) have been used widely for several decades to prevent and treat UTIs. Cranberries comprise nearly $90 \%$ water, but also contain various organic substances such as quinic acid, malic acid and citric acid as well as glucose and fructose. Until recently, it was suggested that the quinic acid caused large amounts of hippuric acid to be excreted in the urine which then acted as an antibacterial agent (Kinney 1979). Several studies, however, have shown no difference in the levels, or only a transient effect thus casting some doubt on this theory (Kahn 1967; McLeod 1978). No definitive mechanism of action has been established for cranberry in the prevention or treatment of UTIs. However, research suggests that cranberries prevent bacteria (particularly Escherichia coli) from adhering to uroepithelial cells that line the wall of the bladder (Schmidt 1988; Zafriri 1989). Without adhesion, E. coli cannot infect the mucosal surface of the urinary tract. In vitro, this adhesion is mediated by two components of cranberry; fructose, which inhibits adherence of type 1 (mannose specific) fimbriated E. coli (Foo 2000; Howell 2007), and substances called proanthocyanidins (PAC), which inhibit the adherence of $\mathrm{p}$-fimbriated (a-galactose-(1-4) specific) $E$. coli (Zafriri 1989). PAC have A- and B- type linkages but It is only the PAC which contain the A-type linkages (found in cranberry juice) which have been associated with preventing adhesion of the E.coli to (Howell 2002; Howell 2005). PAC with B-type linkages are found in a number of sources including commercial apple and grape juice, dark chocolate but these do not appear to have any anti-adhesion effects (Howell 2005).

Cranberry products include juice, syrup, capsules and tablets. A commonly recommended amount for UTI prevention is daily consumption of $300 \mathrm{~mL}$ of cranberry juice cocktail containing 36 mg PAC (Howell 2010). However, processing of cranberries into various products such as tablets or capsules can impact on the PAC composition (Howell 2010) which may result in products which contain little or no PAC - the 'active' anti-adhesion ingredient. In addition, the complexities of the PAC structures and A-type linkages means that measurement of PAC content can often be erroneous and may not be reproducible (Prior 2010). To ensure potency in cranberry powders, levels of PAC must be quantified properly; and the 4-dimethylaminocinnamaldehyde method is currently the most validated standard method for quantifying PAC in cranberry powders (Prior 2010). A randomised controlled trial (RCT) evaluating the dosage effect of cranberry powder found that to achieve a bacterial anti-adhesion effect in urine, $36 \mathrm{mg}$ of cranberry PAC equivalents/d is effective, but $72 \mathrm{mg}$ may offer better protection in some cases. As the anti-adhesion activity decreases over time, it is recommended that cranberries products should be consumed in the morning and in the evening (Howell 2010).

The aim of this review is to assess the effectiveness of cranberries in the prevention of UTIs in susceptible populations including children, women with recurrent UTIs, people with a neuropathic bladder, and older people.

The treatment of UTIs with cranberries is evaluated in another review by the same authors (New Reference).

\section{O B J E C T IVES}

We wished to test the following hypotheses: 
- Cranberry juice/cranberry products are more effective than placebo/no treatment in the prevention of UTIs in susceptible populations.

- Cranberry juice/ cranberry products are more effective than any other treatment in the prevention of UTIs in susceptible populations.

- Different cranberry products (juice, capsules, tablets, concentrate) may differ in the effectiveness for preventing UTIs in susceptible populations

An attempt was also made to quantify the side effects of cranberry juice and the findings were taken into account in the discussion to determine the risk-benefit of the treatment.

\section{ME T HODS}

\section{Criteria for considering studies for this review \\ Types of studies}

All RCTs of cranberry juice (or derivatives) versus placebo, no treatment or any other treatment. Quasi-RCTs (e.g. those studies which randomised participants by date of birth, or case record number) were included, but the quality of the studies was taken into account during the analysis and discussion. Both parallel group and cross-over design were included.

\section{Types of participants}

\section{Inclusion criteria}

Studies of susceptible men, women or children as defined below. These categories were analysed separately.

- Participants with a history of recurrent lower UTIs (more than two episodes in the previous 12 months)

- Elderly men and women

- Participants needing intermittent catheterization

- Pregnant women

- Participants with an in-dwelling catheter

- Participants with an abnormality of the urinary tract

- Children with a first or subsequent UTI.

\section{Exclusion criteria}

- Studies of the treatment of asymptomatic or symptomatic UTI (these are analysed in a separate review by the same authors New Reference).

- Studies of any urinary tract condition not caused by bacterial infection (e.g. interstitial cystitis - a chronic inflammation of the bladder wall).

\section{Types of interventions}

Cranberry juice or a cranberry product (e.g. cranberry capsules, tablets or extract) taken by participants for at least one month. The amount taken/d, concentration of the juice/cranberry product and length of treatment was also taken into account in subgroup analyses.

\section{Types of outcome measures}

\section{Primary outcomes}

- Number (incidence) of UTIs in each group (confirmed by a catheter specimen of urine (CSU), midstream specimen of urine (MSU) if possible, or a 'clean catch' specimen).

The 'gold standard' bacteriological criteria for diagnosis of UTI includes microbiological confirmation from a MSU (or similar method) with greater than 100,000 bacterial $\mathrm{cfu} / \mathrm{mL}$, with some clinicians also requiring concurrent pyuria (white cells in the urine). In some situations a bacterial count $<100,000 / \mathrm{mL}$ is acceptable. For example, when a supra-pubic bladder tap or a catheter urine specimen is obtained. If further studies become available for review, the method of collecting a specimen of urine, the causative organism (e.g. E. coli) and the presence of mixed organisms in the urine (which signifies contamination) will be subject to sensitivity analyses.

If further studies become available for review, this outcome will also be subgrouped into rate of symptomatic lower UTIs, rate of symptomatic upper UTIs (UTI plus fever) and rate of asymptomatic UTIs. Symptomatic is defined as having one or more or the following symptoms: dysuria, frequency, urgency or fever.

Methods used to diagnose upper and lower UTIs will also be subjected to sensitivity analysis if enough data is available.

\section{Secondary outcomes}

- Adherence to therapy.

- Side effects.

\section{Search methods for identification of studies}

\section{Review update}

We searched the Cochrane Renal Group's Specialised Register (4 June 2013) through contact with the Trials' Search Co-ordinator using search terms relevant to this review.

The Cochrane Renal Group's Specialised Register contains studies identified from:

1. Quarterly searches of the Cochrane Central Register of Controlled Trials CENTRAL;

2. Weekly searches of MEDLINE OVID SP;

3. Handsearching of renal-related journals \& the proceedings of major renal conferences;

4. Searching of the current year of EMBASE OVID SP;

5. Weekly current awareness alerts for selected renal-journals;

6. Searches of the International Clinical Trials Register (ICTRP) Search Portal \& ClinicalTrials.gov.

Studies contained in the Specialised register are identified through search strategies for CENTRAL, MEDLINE, and EMBASE based on the scope of the Cochrane Renal Group. Details of these strategies as well as a list of handsearched journals, conference proceedings and current awareness alerts are available in the 'Specialised Register' section of information about the Cochrane Renal Group.

See Appendix 1 for search terms used in strategies for this review. 


\section{Initial search}

Relevant studies were obtained from the following sources.

- Registry of randomised studies for the Cochrane Collaboration Field in Complementary Medicine.

- Companies involved with the promotion and distribution of cranberry preparations were approached and asked to provide information on both published and unpublished studies.

- Electronic databases including PsycLit, LILACS, CINAHL, Biological Abstracts, Current Contents. These databases were searched using the following terms*:

1. (beverages.sh. or cranberr\$.ti,ab or fruit adj5 beverage\$.ti,ab. or fruit adj5 drink\$.ti,ab. or fruit adj5 juice\$ or vaccinium macrocarpon.ti,ab. or vaccinium oxycoccus.ti,ab. or vaccinium vitis-idaea.ti,ab.)

2. (UTIs.sh. or cystitis.sh. or bacteriuria.sh. or pyelonephritis.sh or UTI\$.ti,ab. or urinary adj5 infection\$.ti,ab. or bacter\$.ti,ab. or pyelonephrit\$.ti,ab. or cystitis.ti,ab.)

3. 1 and 2

- The following terms were searched to identify non-English language studies:

- Danish - (Tranebaersaft.ti,ab. or tranebaer.ti,ab. or orkaempetranebaer.ti,ab. or store tranebaer.ti,ab. or cranberry.ti,ab.) and (urinvejsinfektion.ti,ab. or cystitis.ti,ab. or blaerebetaendelse.ti,ab. or pyelonephritis.ti,ab. or pyelonefrit.ti,ab.)

- Dutch - (veenbes.ti,ab. or lepeltjeheide.ti,ab. or lepeltjesheide.ti,ab. or Amerikaanse veenbes.ti,ab. or cranberry.ti,ab.) and (cystitis.ti,ab. or catarrhus.ti,ab. or vesicalis.ti,ab. or blaasontsteking.ti,ab. or urineweginfectie.ti,ab. or pyelonephritis.ti,ab. or nephropyelitis.ti,ab.)

- French - (canneberges ronce d'Amerique.ti,ab. or cranberry.ti,ab. or cranberrie.ti,ab.) and (cystite.ti,ab. or infection urinaire.ti,ab. or pyélonéphrite.ti,ab.)

- German - (moosbeere.ti,ab or kranbeere.ti,ab.) and (zystitis.ti,ab. or cystitis.ti,ab. or harnwegsinfektion.ti,ab. or harninfekt.ti,ab. or pyelonephritis.ti,ab.)

- Italian - (vaccinium oxycoccus.ti,ab. or ossicocco palustro.ti,ab.) and (cistite.ti,ab. or infezione del tratto urinario.ti,ab or infezione urinaria.ti,ab. or infezione delle vie urinarie.ti,ab. or pielonefrite.ti,ab. or nefropielite.ti,ab.)

- Portuguese - (cranberry.ti,ab. or oxicoco\$.ti,ab. or vaccinium oxycoccos.ti,ab. or oxycoccus palustris) and (cistite.ti,ab. or pielonefrite.ti,ab.)

- Spanish - (arandano agrio.ti,ab or arandano americano.ti,ab.) and (cistitis.ti,ab. or infección urinaria.ti,ab or pielonefritis.ti,ab.)

- The Internet was searched using the terms listed.

- Reference lists of review articles and relevant studies were searched.

- Conference abstracts from The Proceedings of the Urological Association (1990-1998), and The Journal of the American Geriatrics Society (1990-1998) were searched for relevant studies for the initial review. Handsearching was then undertaken by the Cochrane Renal Group.

- The National Research Register was searched for studies currently underway.

\section{Data collection and analysis}

The search strategy described previously was employed to obtain titles and, where possible, abstracts of studies that were potentially relevant to the review. The titles and abstracts were screened by RJ and for the 2012 update, GW, who discarded studies that were clearly ineligible but aimed to be overly inclusive rather than risk losing relevant studies. Two authors independently assessed, using full copies of the papers, whether the studies met the inclusion criteria, with disagreements resolved by discussion. Further information was sought from the authors of those papers which contained insufficient information to make a decision about eligibility.

The quality of all studies which were deemed eligible for the review were then assessed independently by two authors, with discrepancies resolved by discussion. The 2012 update included Cochrane risk of bias assessments, these details were recorded by two authors (RJ and GW) and compared for discrepancies. Differences were resolved through discussion and a third author (JC) when necessary. Summary descriptors are provided in the additional tables (Table 1 - Characteristics of studies; Table 2 - Study design and quality of reporting).

Two authors independently extracted information using specially designed data extraction forms. For each included study, information was collected regarding the location of the study, methods of the study (as per quality assessment checklist), the participants (sex, age, eligibility criteria), the nature of the interventions, and data relating to the outcomes specified previously. Where possible, missing data (including side effects) were sought from the authors. All first authors were contacted for more data if necessary. Five authors replied (Kontiokari 2001; NAPRUTI Study 2011 I; Salo 2010; Stothers 2002; Walker 1997) but no additional information was obtained from three of these communications (Walker 1997; NAPRUTI Study 2011 I;Salo 2010). Discrepancies in the data extraction were resolved via discussion.

Studies with either parallel group or cross-over design were included in the review. For cross-over studies, only the period before the cross-over is able to be synthesised in RevMan. However, this data were not available for any of the studies, so end of study data were reported descriptively along with the analysed studies (Table 3 - Positive urine culture (bacteriuria); Table 4 Symptomatic UTIS). Risk ratio (RR) was used as the measure of effect for dichotomous outcomes, using a random effects model. Studies were sub-grouped by population type (e.g. older people, women with recurrent UTIs). If enough data becomes available in the future, heterogeneity in the data will be noted and cautiously explored using previously identified characteristics of the studies, particularly assessments of quality. Sensitivity analyses will be undertaken to examine the stability of the results in relation to a number of factors including study quality, the source of the data (published or unpublished), the method used for confirming the presence of bacteria in the urine (e.g. CSU or MSU specimen of urine), the causative organism (e.g. E. coli) and the method of diagnosing upper or lower UTI. 


\section{RESULTS}

\section{Description of studies}

\section{Included studies}

Ten studies (1049 participants) were included in the previous version (four cross-over studies and six studies with a parallel design). Of these, two were only published as letters, and no additional data were received from the authors (Haverkorn 1994; Walker 1997). A further 14 studies were added in the current update (one cross-over and 13 parallel design). Across all 24 included studies, 11 studies (2249 participants) evaluated a cranberry juice product (Avorn 1994; Barbosa-Cesnik 2011; Cowan 2012; Essadi 2010; Foda 1995; Haverkorn 1994; Kontiokari 2001; McMurdo 2005; Salo 2010; Schlager 1999; Wing 2008), 10 studies (1032 participants) evaluated cranberry tablets/capsules (Hess 2008; Lee 2007; Linsenmeyer 2004; McGuiness 2002; McMurdo 2009; NAPRUTI Study 2011 I; PACS Study 2008; Sengupta 2011; Waites 2004; Walker 1997), two studies (131 participants) evaluated a liquid cranberry concentrate/syrup (Ferrara 2009; Uberos 2010); one study compared cranberry juice and tablets (Stothers 2002); and one study compared cranberry capsules and tablets (PACS Study 2008). Studies compared cranberry product with a placebo, no treatment, water, Methenamine Hippurate and antibiotic treatment. Six studies included a third arm comparator. Of these, four studies included another cranberry product arm (PACS Study 2008; Sengupta 2011; Stothers 2002; Wing 2008) and one study included a probiotic Lactobacillus GG arm (Ferrara 2009). One study used a four arm factorial design of cranberry, placebo and methenamine hippurate (Lee 2007) .

\section{Types of participants}

Participants with a history of recurrent lower UTIs or young women with an uncomplicated UTI

Seven studies included women with current (Barbosa-Cesnik 2011; Kontiokari 2001) and recurrent UTIs (McMurdo 2009; NAPRUTI Study 2011 I; Sengupta 2011; Stothers 2002; Walker 1997). The definition that the studies used for recurrent UTIs varied between two and four UTIs in the past 12 months and in one study (Sengupta 2011) was simply stated as history of recurrent UTI. Of these studies, five compared cranberry product(s) with placebo (Barbosa-Cesnik 2011; Kontiokari 2001; Sengupta 2011; Stothers 2002; Walker 1997) and two compared cranberry products with antibiotics (McMurdo 2009; NAPRUTI Study 2011 I).

\section{Elderly men and women}

Four studies evaluated cranberry juice for the prevention of UTIs in elderly populations (Avorn 1994; Haverkorn 1994; McMurdo 2005; PACS Study 2008). The largest and best quality study (McMurdo 2005) included 360 hospital patients aged 60 years or over who were randomised to daily ingestion of $300 \mathrm{~mL}$ of cranberry juice or matching placebo beverage using a parallel group design. Avorn 1994 was a quasi-randomised, parallel group study of elderly women randomised to either cranberry juice or placebo juice. Although 192 women were initially randomised to treatment, only 153 provided enough data to be included in the final analysis. Haverkorn 1994 used a cross-over design and included 38 men and women randomised to either cranberry juice or water. Only 17 completed treatment and seven were included in the final analysis. The fourth study was a small (59 participants), three-armed study of a cranberry capsule, cranberry tablet or placebo (PACS Study 2008).
Participants (adults and children) needing catheterisation (intermittent or indwelling)

Six studies evaluated the effect of cranberry products in people needing either indwelling catheters or intermittent catheterisation (Foda 1995; Hess 2008; Lee 2007; Linsenmeyer 2004; Schlager 1999; Waites 2004). Four of the studies evaluated the effectiveness of cranberry capsules/tablets versus placebo in adults with spinal cord injuries (Hess 2008; Lee 2007; Linsenmeyer 2004; Waites 2004) of which two were cross-over studies (Hess 2008; Linsenmeyer 2004), one was a parallel group study (Waites 2004), and one used a four-arm factorial design comparing cranberry product with methenamine hippurate and placebo (Lee 2007). In the other two studies (Foda 1995; Schlager 1999), participants were children who had a paediatric neuropathic bladder and were managed by clean intermittent catheterisation. Both were cross-over studies which compared cranberry juice to placebo/water and included 40 and 15 children respectively.

\section{Pregnant women}

Two studies (659 participants) (Essadi 2010; Wing 2008) enrolled pregnant women. Wing 2008 was a three-arm study comparing a single daily dose $(240 \mathrm{~mL})$ or two, three daily doses of cranberry juice ( $640 \mathrm{~mL}$ to $720 \mathrm{~mL}$ ) with a placebo beverage. Essadi 2010 compared four daily doses (totalling $1000 \mathrm{~mL}$ ) of cranberry juice with the same volume of water.

\section{Children at risk of repeat UTI}

Three studies enrolled children at risk of, or susceptible to, repeat UTI (Ferrara 2009; Salo 2010; Uberos 2010). Two studies (Ferrara 2009; Uberos 2010) included children who had experienced more than one UTI with and Salo 2010 enrolled children at their first UTI. All tested the effectiveness of different cranberry products. Salo 2010 compared cranberry juice with placebo; Uberos 2010 compared cranberry syrup versus trimethoprim syrup; and Ferrara 2009 compared cranberry plus lingonberry concentrate with lactobacillus.

\section{Other populations}

Cowan 2012 included patients undergoing radiation treatment for bladder or cervical cancer and compared two daily doses of cranberry juice with a placebo beverage. McGuiness 2002 compared cranberry capsules with placebo and included patients with multiple sclerosis, of which 72 voided naturally and 63 used intermittent self catheterisation.

\section{Dosage, concentration and formulation of cranberries}

The rationale behind the dosage and concentration of cranberry juice given to participants was not clearly described in any of the studies, and only five studies (Barbosa-Cesnik 2011; McMurdo 2005; NAPRUTI Study 2011 I; Uberos 2010; Wing 2008) described the amount of PAC - the compound considered to be the 'active' ingredient - in the cranberry juice.

\section{Cranberry juice or cranberry concentrate}

Of the 14 studies (13 studies of only cranberry juice/concentrate plus one juice and another cranberry product) evaluating the effectiveness of cranberry juice, the comparison group varied. Eight studies used placebo juice for the control arm (Avorn 1994; Barbosa-Cesnik 2011; Cowan 2012; McMurdo 2005; Salo 2010; Schlager 1999; Stothers 2002; Wing 2008), one studies 
used no intervention (Kontiokari 2001;), three studies used water (Essadi 2010; Foda 1995; Haverkorn 1994), one used lactobacillus as a control (Ferrara 2009) and one used antibiotic treatment (Uberos 2010). For adults, the amount given ranged from $30 \mathrm{~mL} / \mathrm{d}$ (Haverkorn 1994) to $1000 \mathrm{~mL} / \mathrm{d}$ (Essadi 2010). In studies including children, Foda 1995 reported using 15 mL/kg; Schlager 1999 used $300 \mathrm{~mL} / \mathrm{d}$; Ferrara 2009 stated using $50 \mathrm{~mL}$ of concentrate; Uberos 2010 used $0.2 \mathrm{~mL} / \mathrm{kg}$ of cranberry concentrate; and Salo 2010 reported $15 \mathrm{~mL} / \mathrm{kg}$ to $300 \mathrm{~mL}$ once or twice daily.

\section{Cranberry capsules or tablets}

Eleven studies evaluating the effectiveness of cranberry capsules or tablets (Hess 2008; Lee 2007; Linsenmeyer 2004; McGuiness 2002; McMurdo 2009; NAPRUTI Study 2011 I; PACS Study 2008; Sengupta 2011; Stothers 2002; Waites 2004; Walker 1997). The total dose/d ranged from $400 \mathrm{mg}$ (Walker 1997) to $2000 \mathrm{mg}$ (Waites 2004). Only one study described the amount of PAC (Sengupta 2011) and others such as McGuiness 2002 stated that, because they did not measure PAC, they may have used a product that contained no PAC.

\section{Outcome measures}

In all of the studies, symptomatic UTI and/or positive urine culture were reported as the primary outcome measures. The outcome reported in this review is the number of people experiencing at least one symptomatic UTI at the end of the follow-up period.

\section{Excluded studies}

Eight studies were excluded because although they were randomised and compared cranberry juice with placebo in susceptible populations, they did not meet other inclusion criteria (Howell 2010; Jackson 1997; Jass 2009; Lavigne 2008; Schultz 1984; Tempera 2010; Valentova 2007; Vidlar 2010);(see Characteristics of excluded studies for more details).

\section{Risk of bias in included studies}

Figure 1 is a risk of bias graph showing the review authors' judgements about each risk of bias item, presented as percentages across all included studies. Figure 2 is a risk of bias summary showing the review authors' judgements about each risk of bias item for each included study.

Figure 1. Risk of bias graph: review authors' judgements about each risk of bias item presented as percentages across all included studies.

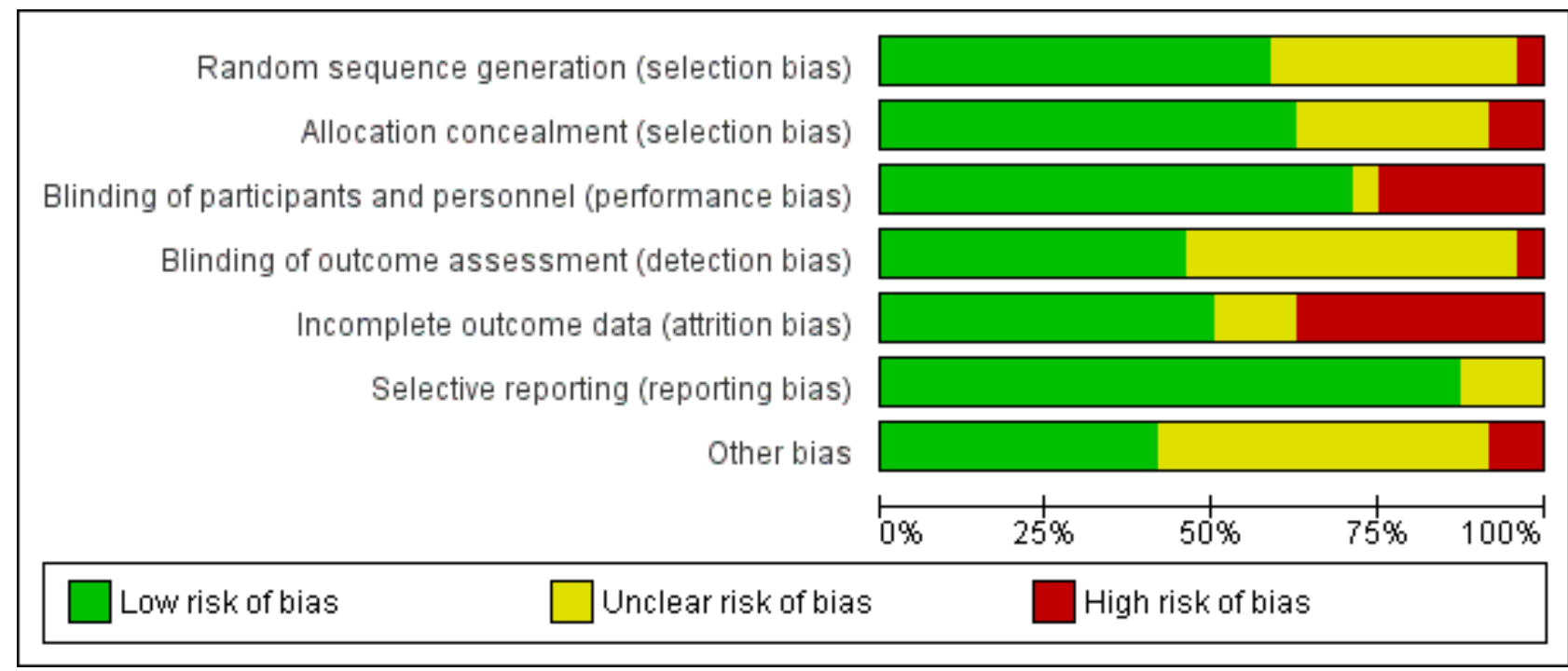


Figure 2. Risk of bias summary: review authors' judgements about each risk of bias item for each included study.

\begin{tabular}{|c|c|c|c|c|c|c|c|}
\hline & 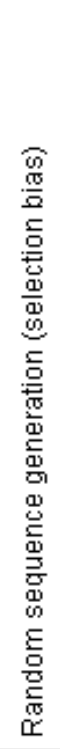 & 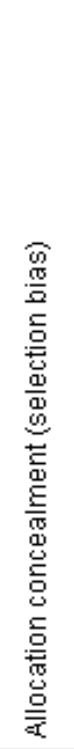 & 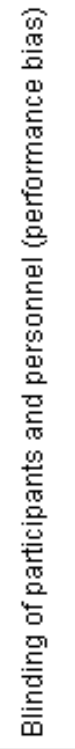 & 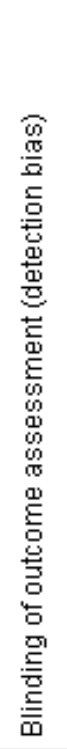 & 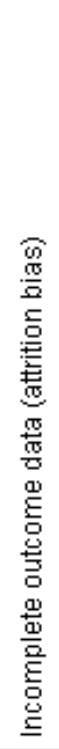 & 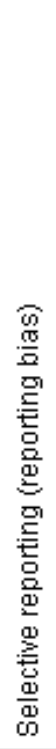 & 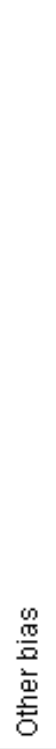 \\
\hline Avorn 1994 & 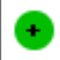 & $\odot$ & $\odot$ & $?$ & $\odot$ & + & - \\
\hline Barbosa-Cesnik 2011 & 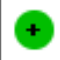 & + & + & $?$ & $\odot$ & + & $\odot$ \\
\hline Cowan 2012 & $\oplus$ & + & + & $?$ & $\odot$ & + & + \\
\hline Essadi 2010 & $?$ & $?$ & - & $?$ & - & + & $?$ \\
\hline Ferrara 2009 & + & $?$ & $\odot$ & $?$ & $\odot$ & + & ? \\
\hline Foda 1995 & ? & $?$ & $\odot$ & $?$ & + & $?$ & $?$ \\
\hline Haverkorn 1994 & - & $\odot$ & $?$ & $?$ & $\odot$ & $?$ & $?$ \\
\hline Hess 2008 & $?$ & $\odot$ & $\odot$ & + & $\Theta$ & + & + \\
\hline Kontiokari 2001 & + & + & $\Theta$ & + & + & + & $?$ \\
\hline Lee 2007 & + & + & + & + & + & + & + \\
\hline Linsenmeyer 2004 & $?$ & $?$ & $\odot$ & + & + & + & $?$ \\
\hline McGuiness 2002 & ? & ? & + & $?$ & ? & + & ? \\
\hline McMurdo 2005 & + & $\odot$ & $\odot$ & + & + & + & + \\
\hline McMurdo 2009 & + & + & $\odot$ & + & + & + & + \\
\hline NAPRUTI Study 2011 I & + & $\odot$ & $\odot$ & + & $\odot$ & + & $\odot$ \\
\hline PACS Study 2008 & ? & $?$ & $\odot$ & $\Theta$ & ? & ? & ? \\
\hline Salo 2010 & + & + & $\odot$ & ? & + & + & $\odot$ \\
\hline Schlager 1999 & $?$ & + & + & + & + & + & + \\
\hline Sengupta 2011 & + & + & $\odot$ & $?$ & $?$ & + & $?$ \\
\hline Stothers 2002 & + & + & + & 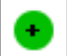 & + & + & + \\
\hline
\end{tabular}


Figure 2. (Continued)

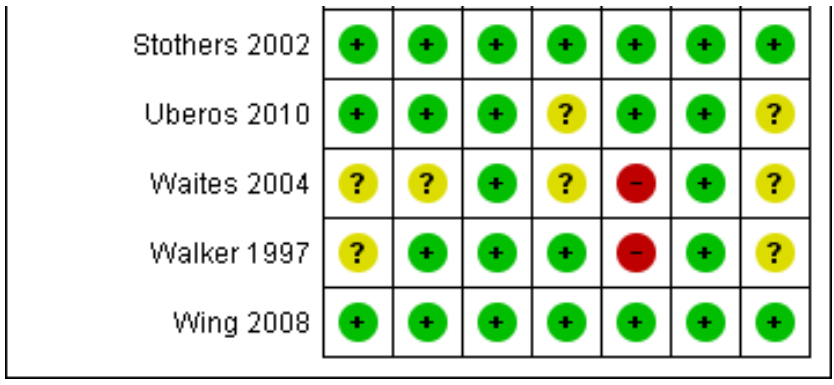

\section{Allocation}

\section{Random sequence generation}

Fourteen studies reported a method of random sequence generation that was judged to be at low risk of introducing bias, in eight studies the issue was unclear and for two studies (Avorn 1994; Haverkorn 1994) the method was considered at high risk of introducing bias (Figure 2)

\section{Allocation concealment}

Fifteen studies reported a method of allocation concealment considered to be at low risk of bias, in six studies this issue was unclear and for two studies the method reported was judged as being at high risk of introducing bias (Figure 2).

\section{Blinding}

Seventeen of the studies stated that participants and study personnel were blind to treatment allocation, five studies had no blinding, and for one study this issue was unclear (Essadi 2010). In 13 studies the outcome assessor was either stated as blinded (or assumed to be blinded based on study design) and in nine studies it was unclear whether the outcome assessor was blind to treatment allocation.

\section{Incomplete outcome data}

Twelve studies reported complete outcome data, eight studies had incomplete outcome data and for four studies this issue was unclear.

\section{Selective reporting}

Twenty studies reported the most appropriate outcomes for the study design, repeat symptomatic UTI or positive urine culture, while for three studies selective reporting issues were unclear.

\section{Withdrawals, losses to follow-up and intention-to-treat}

The dropout rate varied considerably across the studies, from $0 \%$ to $55 \%$. Six studies included all randomised participants in their analysis (Lee 2007; McMurdo 2009; PACS Study 2008; Schlager 1999; Stothers 2002; Wing 2008) whilst the remaining studies - where this was able to be determined - excluded between 5\% and 55\% of the randomised participants from the outcome analyses. One study (McGuiness 2002) reported that it used an intention-to-treat analysis, but the results do not concur with this assertion.

Several studies stated that palatability of the cranberry product (primarily cranberry juice) was assumed to be the reason for participants discontinuing or withdrawing from the study, but none provided actual data about this from participants.

At least one of the studies had serious flaws. In Avorn 1994 some of the baseline characteristics of the participants were markedly different in the cranberry and the placebo group. In particular, the rate of UTIs in the previous six months in the placebo group was over three times that of the cranberry juice group, and double for over 12 months. Two letters, published in JAMA, commented on these differences and inferred that the randomisation and/or blinding scheme had failed (Hopkins 1994; Katz 1994).

All but five studies (Barbosa-Cesnik 2011; Essadi 2010; Lee 2007; McMurdo 2005; Uberos 2010) were likely to be underpowered to detect a realistic difference between placebo and cranberry product. The studies stating power calculations made rather optimistic estimates of the benefit of cranberry product (for example a two-fold difference in Barbosa-Cesnik 2011; 1.3 times greater in NAPRUTI Study 2011 I; 20\% difference Cowan 2012; 35\% difference Hess 2008) and as such the sample size calculations for some studies was small and declined further with the high withdrawal rates.

\section{Effects of interventions}

\section{Cranberry product compared with placebo or no treatment Overall}

Across the combined population of patients, 13 studies (2462 participants) had data which were able to be analysed. The combined estimated RR of repeat UTI with cranberry treatment was not statistically significant (Analysis 1.1: RR $0.86,95 \% \mathrm{Cl}$ 0.71 to 1.04 ). Twelve studies had data which could not be metaanalysed. Of these, eight studies reported no effect, and two small studies reported a significant effect of cranberries compared to placebo (Hess 2008; Walker 1997). There was moderate overall heterogeneity $\left(I^{2}=53 \%\right)$ but no significant between study heterogeneity $\left(I^{2}=5.2 \%\right)$.

\section{Women with a recurrent UTI}

Four of the five studies (594 participants) which included a placebo group provided data that could be combined in a meta-analysis (Kontiokari 2001; Barbosa-Cesnik 2011; Stothers 2002; Sengupta 2011). Results showed a small, non-significant reduction in risk of repeat symptomatic UTI with cranberry treatment compared to placebo or no treatment (Analysis 1.1.1: RR $0.74,95 \% \mathrm{Cl} 0.42$ to 1.31). However there was significant heterogeneity in the results, primarily with the addition of the newest largest study (BarbosaCesnik 2011) $\left(I^{2}=65 \%\right)$. When this study was omitted from the 
meta-analysis, the RR was 0.58 ( $95 \% \mathrm{Cl} 0.39$ to 0.86$)$. There may be several reasons why Barbosa-Cesnik 2011 showed different results to the other studies (i.e. no effect of cranberries). As they discuss, theirs was the only study which was powered sufficiently to detect a difference (it had a larger sample size than the other three put together). However, they do use a different (lower) threshold for defining a UTI than the other studies, although measurement of symptoms would have been similar.

The other study (Walker 1997) was published as a letter with no comparable data. In this study there were 21 incidents of UTIs amongst the 10 people who completed the study. Six were in the treatment group, and 15 were in the placebo group $(P<0.005)$ (see Table 4).

\section{Older men and women}

Overall the data from the studies in older men and women suggest that cranberries are not effective in preventing UTIs. Of the four studies evaluating the effectiveness of cranberry product(s) versus placebo in the population group, two studies were of high quality and had data available for analysis (McMurdo 2005; PACS Study 2008) (Analysis 1.1.2 (2 studies, 413 participants): RR $0.75,95 \% \mathrm{Cl}$ 0.39 to 1.44). The other studies had significant flaws. Avorn 1994 reported $4 \%(20 / 473)$ of the urine samples in the treatment group and $7 \%(37 / 498)$ in the placebo group had bacteriuria and pyuria concurrent with the subjects reporting urinary tract symptoms $(P$ = not significant). These figures, however, appear to include the baseline urine samples (i.e. before the participants began drinking either cranberry juice or placebo juice). Haverkorn 1994 gave no details about symptomatic UTIs. See Table 4 for more results from these two studies.

\section{Participants (adults and children) needing catheterisation (intermittent or indwelling)}

Overall the evidence from six studies suggest there is no benefit of cranberry juice in reducing UTIs in this population group. Only two of these studies had relevant data for a meta-analysis (Lee 2007; Waites 2004). When we combined the results of these studies there was no difference between the cranberry and placebo groups (Analysis 1.1.3 (2 studies, 353 participants): RR 0.95, 95\% Cl 0.75 to 1.20). The other four studies were cross-over studies. One (Hess 2008) found a significant effect, two reported a non-significant effect (Foda 1995; Schlager 1999) and one only had asymptomatic UTIs as an outcome (Linsenmeyer 2004).

\section{Pregnant women}

Overall cranberry juice was found not to be effective in reducing UTIs in pregnant women. The two studies in pregnant women (Essadi 2010; Wing 2008) provided data that could be analysed, but these showed widely different results with combined RR of 1.04 (95\% Cl 0.93 to 1.16) (Analysis 1.1.4). Both studies evaluated relatively large quantities of cranberry juice (up to $1000 \mathrm{~mL}$ / d) and both had a high number of withdrawals (39\% and $28 \%$ respectively). In one of the studies (Wing 2008), the number of withdrawals was so high that the dose was reduced from $720 \mathrm{~mL} /$ $\mathrm{d}$ to $540 \mathrm{~mL} / \mathrm{d}$.

\section{Children with a susceptibility to UTIs}

The overall evidence suggested that cranberry products are not effective for preventing UTIs in children. Two studies (Ferrara 2009; Salo 2010) in children showed a non-significant reduction in risk of repeat symptomatic UTI with cranberry treatment compared to placebo (RR $0.48,95 \% \mathrm{Cl} 0.19$ to 1.22 ) (Analysis 1.1.5). The third study (Uberos 2010) was only published as an abstract and it was not clear whether the results were presented for symptomatic UTIs or just a positive culture.

\section{Other populations}

A single study (Cowan 2012) reported data in patients undergoing radiation treatment and showed a non-significant increased risk of repeat UTI with cranberry product (RR $1.15,95 \% \mathrm{Cl} 0.75$ to 1.77 ) (Analysis 1.1.6). Another study of people with multiple sclerosis (either voiding naturally or using intermittent self catheterisation (McGuiness 2002) found no significant difference between the cranberry capsule or control group (34.6\% of people versus $32.6 \%$ ).

\section{Cranberry product compared with antibiotic prophylaxis}

Two studies in women with recurrent UTI (McMurdo 2009; NAPRUTI Study 2011 I) and one study in children (Uberos 2010), compared cranberry product with antibiotic prophylaxis. All three studies used either cranberry capsules or syrup, rather than cranberry juice. Analysis of the two studies in women showed that cranberry product compared to antibiotic were equally as effective in reducing the risk of repeat UTI in women (Analysis 2.1.1: RR 1.31, $95 \% \mathrm{Cl} 0.85$ to 2.02 ) The study in children also showed that the cranberry product were equally as effective in reducing the risk of repeat symptomatic UTI compared to antibiotics (Analysis 2.1.2: RR $0.69,95 \% \mathrm{Cl} 0.32$ to 1.51$)$.

\section{Low (1 dose) versus high ( $\geq 2$ doses) dose cranberry product}

Three studies compared high versus low dose cranberry products (PACS Study 2008; Sengupta 2011; Wing 2008). There was no significant difference between two different doses of cranberry product (Analysis 3.1 (3 studies, 208 participants): RR 1.12, 95\% Cl 0.75 to 1.68$)$.

\section{High dose cranberry versus placebo}

Three studies in different populations - pregnant women (Wing 2008); elderly men and women (PACS Study 2008); and adult women (Sengupta 2011) - compared high dose cranberry product to placebo. There was significant heterogeneity, both overall $\left(\mathrm{I}^{2}=\right.$ $55 \%)$ and between the subgroups $\left(I^{2}=54.5 \%\right)$ and we therefore did not pool the results. The results ranged from RR $5.42(95 \% \mathrm{Cl} 0.27$ to 110.66 ) in pregnant women (Wing 2008) to RR 0.28 (95\% Cl 0.06 to 1.34) in adult women (Sengupta 2011) (Analysis 4.1).

\section{Cranberry versus complementary therapies}

A single study (Lee 2007) compared cranberry product with methenamine hippurate in patients with spinal injury and showed no difference between the groups (Analysis 5.1: RR 1.02, 95\% Cl 0.79 to 1.31 ).

Two studies, one in children (Ferrara 2009) and one in adult women (Kontiokari 2001), compared cranberry with a probiotic treatment and showed a significant reduction in symptomatic UTI with cranberry compared to probiotic (Analysis 6.1 (2 studies, 152 participants): $\mathrm{RR} 0.42,95 \% \mathrm{Cl} 0.24$ to 0.74 ).

\section{Adverse effects}

Across all studies, adverse effects were not well reported with only seven studies stating the number of adverse events within each 
study arm (McMurdo 2005; McMurdo 2009; NAPRUTI Study 2011 I; PACS Study 2008; Sengupta 2011; Stothers 2002; Wing 2008). There were usually fewer than 10 adverse events (except NAPRUTI Study 2011 I), which were mild and similarly distributed across the treatments arms (Analysis 1.2; Analysis 2.2; Analysis 3.2; Analysis 4.2). Three further studies mentioned adverse events but did not report them by study arm (Barbosa-Cesnik 2011; Cowan 2012; Lee 2007).

\section{Adherence to therapy}

Sixteen studies reported measuring compliance. Of these, ten used self reporting and five used a pill or bottle count (Avorn 1994; Hess 2008; McMurdo 2009; Schlager 1999; Stothers 2002). One study measured the presence of antibiotic activity in urine samples (NAPRUTI Study 2011 I). Seven studies did not state that they measured adherence (Essadi 2010; Haverkorn 1994; Lee 2007; Linsenmeyer 2004; PACS Study 2008; Sengupta 2011; Uberos 2010). Results of adherence monitoring were highly variable and several studies reported participants withdrawing because of the unpalatable or intolerable nature of the cranberry product.

\section{Withdrawals and losses to follow-up}

The withdrawal/drop-out rate and losses to follow-up varied considerably between the studies. Five studies reported no withdrawals or losses to follow-up (Lee 2007; Schlager 1999; Stothers 2002; Sengupta 2011; Uberos 2010). In the other studies the drop-out, withdrawal or loss to follow-up rates ranged from $3 \%$ to $55 \%$. Rates, from low to high, for the individual studies were: 3\% (PACS Study 2008), 5\%(Ferrara 2009), 8\% (Kontiokari 2001; Hess 2008), 10\% (Salo 2010), 12\% (Cowan 2012; McMurdo 2009), 20\% (Avorn 1994), 24\% (Barbosa-Cesnik 2011) 30\% (McMurdo 2005), 32\% (NAPRUTI Study 2011 I) 35\% (Waites 2004),39\% (Wing 2008) 40\% (Essadi 2010) 43\% (Linsenmeyer 2004), 47\% (Foda 1995; Walker 1997) and 55\% (Haverkorn 1994). Only six of the studies used an intention-to-treat analysis (Lee 2007; Kontiokari 2001; McMurdo 2005; McMurdo 2009; PACS Study 2008; Wing 2008).

\section{Cost effectiveness}

One study (Stothers 2002) reported on the cost effectiveness of the intervention. The mean annual cost of prophylaxis was CAD 624 and CAD 1400 for cranberry tablets and juice respectively. Cost savings were greatest when patients experienced more than two symptomatic UTIs/year (assuming three days of antibiotic coverage) and had more than two days of missed work or required protective undergarments for urgency incontinence. Total antibiotic consumption was less annually in both treatment groups compared with placebo. The authors of the study reported that cost effectiveness ratios demonstrated cranberry tablets were twice as cost effective as organic juice for prevention.

\section{DISCUSSION}

\section{Summary of main results}

In the last update of this review (Jepson 2008) we concluded that 'There was some evidence to show that cranberries (juice and capsules) can prevent recurrent infections in women. However, the evidence for elderly men and women was less clear, and there is evidence that is not effective in people who need catheterisation. In this update, with the addition of 14 new studies, it has become more evident that cranberry products do not significantly reduce the risk of repeat symptomatic UTI compared to placebo or no treatment in groups of people at risk of repeat UTI (overall RR $0.86,95 \% \mathrm{Cl} 0.71$ to 1.04 ) or for any of the subgroups analysed. There was however moderate heterogeneity (53\%), which is largely unexplained. The two studies in children suggest the greatest effect (RR $0.48,95 \% \mathrm{Cl} 0.19$ to 1.22 ), however this result was not significant, reflecting the small sample size and infrequency of events. In adult women (RR $0.74,95 \% \mathrm{Cl} 0.42$ to 1.31 ) and the elderly (RR $0.75,95 \% \mathrm{Cl} 0.39$ to 1.44 ) the Cls were wide and do not reach not statistical significance. Studies in pregnant women, patients with spinal injury or neuropathic bladder, people with multiple sclerosis, and people receiving radiation therapy showed no significant benefit to cranberry product with RRs close to 1 .

Three studies compared cranberry product with antibiotic treatment, two in adult women and one in children. When pooled, the two studies in women showed no significant difference in terms of risk of repeat UTI for women taking cranberry product while the study in children suggested the lower risk of repeat infection for those taking cranberry products compared with antibiotics.

\section{Overall completeness and applicability of evidence}

Several sub-groups of the populations are at increased risk of repeat UTI and the majority of these groups are represented in studies included in this review. Adult women were most frequently studied (seven studies) and the range of other susceptible population groups - children, the elderly, pregnant women, those with a spinal injury, neuropathic bladder, multiple sclerosis or undergoing radiotherapy - were included.

From the evidence it is unlikely that cranberry in its juice form is going to be an acceptable and effective intervention, even if the anti-adhesion can be demonstrated in vitro. Effectiveness of the cranberry juice in non-research populations is likely to be dependant on high adherence to the amount and the timing. To maintain levels of cranberry PAC that are necessary to prevent antiadhesion, people would have to continuously drink the juice twice a day in serving of $150 \mathrm{~mL}$ for an indefinite period of time. If a woman only has two UTIs a year she would have to drink the juice twice a day for a year to potentially have one less UTI. Although for some women this regime may be acceptable (i.e. those who have a high rate of occurrence), others may find that the price, the calories in the juice, and the taste may make it less appealing.

Given the potential drawbacks of drinking cranberry juice for long periods, in recent years there have been an increasing number of studies evaluating the effectiveness of cranberry products such as tablets and capsules (Hess 2008; Lee 2007; Linsenmeyer 2004; McGuiness 2002; McMurdo 2009; NAPRUTI Study 2011 I; PACS Study 2008; Sengupta 2011; Stothers 2002; Waites 2004; Walker 1997). However, processing of cranberry into various products such as tablets or capsules can impact on the PAC composition (Howell 2010). Thus, proper standardization of cranberry products for PAC content, and correlation of the PAC level with anti-adhesion bioactivity, may be important to ensure that particular cranberry products contain PAC that are efficacious( Howell 2010). Howell 2010 suggested that at least $36 \mathrm{mg}$ of cranberry PAC equivalents/d is required to be effective, divided into two doses, one in the morning and one at night. Only three studies measured PAC content in non-juice products (NAPRUTI Study 2011 I; Sengupta 2011; Uberos 2010). The PAC content reported in NAPRUTI Study 2011 I was 9.1 $\mathrm{mg} / \mathrm{g}$; 1.5\% in Sengupta 2011; and in Uberos 2010 (of children) 5 
$\mathrm{mL}$ of the syrup contained $36 \mathrm{mg}$. The other studies of non-juice products did not report the PAC content, and thus it is not possible to ascertain whether the products used contained enough PAC content to be effective. There are currently three studies (Bonetta 2011; NCT00280592; NCT01033383) evaluating cranberry tablets or capsules which have not reported enough data to be included in this review update. More studies of cranberry capsules or tablets containing PAC amounting at least $36 \mathrm{mg} / \mathrm{d}$, quantified using a standard measure, and taken twice daily may be warranted but potentially only for women with recurrent UTIs.

\section{Quality of the evidence}

Study design in most studies was relatively robust and free from significant bias. The biggest weakness of the evidence was in attrition bias due to the large number of participants who were randomised but not included in the outcome analysis (intentionto-treat). Not using an intention-to-treat analysis undermines the randomisation process and such an analysis was only undertaken in six studies. A further limitation to the findings is the small size of most studies; most studies lacked power to detect a realistic significant difference between treatment groups and even combining the few studies with similar populations and treatment, did not greatly improve this issue.

\section{Potential biases in the review process}

Data extraction was completed independently by two authors without financial interest in the outcome. Data compilation for the new studies in the current update was completed by an author uninvolved in the previous review and without expectations for results. In summary authors believe the review update was an unbiased process limited only by the adequacy of reporting in the included studies.

\section{Agreements and disagreements with other studies or reviews}

The most recent and robust systematic review that evaluated cranberry products versus placebo was published in 2012 (Wang 2012). Although the search strategy and inclusion/exclusion criteria were similar, the Wang 2012 only contained 13 studies (1616 participants) compare to this review with 24 studies (4473 participants). The main difference was that the authors did not include studies that compared cranberry products with another intervention (e.g. antibiotics). However, despite this difference, the review did not contain several placebo controlled studies that were included here (Cowan 2012; Essadi 2010; Lee 2007; Linsenmeyer 2004; NAPRUTI Study 2011 I; PACS Study 2008; Salo 2010; Sengupta 2011; Uberos 2010). Overall Wang 2012 reported similar results to this review. The main difference was their decision to exclude one of the studies with women with recurrent UTIs from their metaanalysis (Barbosa-Cesnik 2011). They excluded the study because there was significant heterogeneity in the results - the BarbosaCesnik 2011 study was the only one in the subgroup of women with recurrent UTIs which showed no effect of cranberry on the incidence of UTIs. Wang 2012 hypothesised that one of the reason for the different results in this study could be due to the threshold which Barbosa-Cesnik 2011 used to define a UTI. It was the lowest at $10^{3} \mathrm{cfu} / \mathrm{mL}$; most of the other studies used a threshold of $10^{5} \mathrm{cfu} /$ $\mathrm{mL}$. However, since this threshold was used to define a UTI in both the control and intervention group in the study, this is unlikely to be the explanation. As the weighted prior probability of UTI varies across diagnostic threshold: $65.1 \%$ at $\geq 10^{2} \mathrm{cfu} / \mathrm{mL} ; 55.4 \%$ at $\geq 10^{3}$ $\mathrm{cfu} / \mathrm{mL}$; and $44.8 \%$ at $\geq 10^{5} \mathrm{cfu} / \mathrm{mL}$ (Giesen 2010 ), you would expect to see more UTIs identified at a lower threshold, but this was not the case in this study. The incidence rate was $16.9 \%$, almost half what would have been expected (27\%), based on the literature (Foxman 2000). Therefore the study population may have been women who were less at risk of recurrent UTIs. We decided to include the study in our meta-analysis because it was the largest study, the only one which used blinding, and did a power calculation, and therefore likely to have the most robust results. Wang 2012 also undertook subgroup analysis of cranberry juice versus tablets or capsule and found that juice was more effective but hypothesised that one reason for this could be that the participants who drank the cranberry juice were more hydrated.

\section{AUTHORS' CONCLUSIONS}

\section{Implications for practice}

The current body of evidence suggest that cranberry products (either in juice or as capsules/tablets) compared to placebo provides no benefits in most populations groups, and the benefit in some subgroups is likely to be very small. The large number of dropouts/withdrawals from some of the studies indicates that cranberry products, particularly in juice form, may not be acceptable over long periods of time. Cranberry capsules or tablets may overcome some issues with compliance, but from current evidence they do not appear to be any more effective than juice, although they may be as effective as antibiotics. One of the drawbacks of the studies of non-juice products, such as capsules, is few of the triallists reported how much 'active' ingredients (if any) were in the tablets or capsules they used. Until there are more studies of products containing enough of the active ingredient, measured in a standardised way, cranberry products cannot be recommended for preventing UTIs.

\section{Implications for research}

A significant number of RCTs have now been conducted to assess the effectiveness of cranberry products for preventing UTIs, particularly in its juice form. Given the majority of studies indicate the benefit is likely to be small at best, and with poor adherence, further studies of cranberry juice are only likely to support this conclusion, and should not be undertaken without strong justification. More studies of cranberry products such as tablets and capsules may be justified, but only for women with recurrent UTIs, and only if they contain the recommended amount of PAC (at least $36 \mathrm{mg} / \mathrm{d}$ ) which is quantified using standardised and validated measures.

\section{ACKNOWLEDGEMENTS}

- Ruth Jepson would like to thank the Nuffield Trust for giving her a short term fellowship for the original version of this review. She would also like to thank Dr Amy Howell for providing useful insights and into the mechanisms of action, structure of PAC, and preparations of non-juice products. The authors are grateful to Dr Lara Mihaljevic who contributed to the original iteration of this review (Jepson 1998a; Jepson 2004b), contributing to the study selection, quality assessment and data extraction.

- The authors would also like to thank the following people for replying to correspondence:

- Dr Lyn Stothers (Stothers 2002) 
- Prof Tero Kontikari (Kontiokari 2001)

- Dr Ed Walker (Walker 1997)

- Dr RJ Woodward (Larkhill Green Farm - cranberry tablets)

- Professor Marion McMurdo (McMurdo 2005)
- Dr Marielle Beerepoot (NAPRUTI Study 2011 I)

- We would also like to thank Narelle Willis (Managing Editor, Cochrane Renal Group) for her input into the review.

- Funding for the 2012 update was provided by the UK NHS NIHR 


\section{R E F E R E N C E S}

\section{References to studies included in this review}

\section{Avorn 1994 \{published data only\}}

Avorn J, Monane M, Gurwitz J, Glynn R. Reduction of bacteriuria and pyuria with cranberry beverage: a randomized trial [abstract]. Journal of the American Geriatrics Society 1993;41(10 Suppl):SA13.

* Avorn J, Monane M, Gurwitz JH, Glynn RJ, Choodnovskiy I, Lipsitz LA. Reduction of bacteriuria and pyuria after ingestion of cranberry juice. JAMA 1994;271(10):751-4. [MEDLINE: 8093138]

\section{Barbosa-Cesnik 2011 \{published data only\}}

Barbosa-Cesnik C, Brown MB, Buxton M, Zhang L, DeBusscher J, Foxman $B$. Cranberry juice fails to prevent recurrent urinary tract infection: results from a randomized placebo-controlled trial. Clinical Infectious Diseases 2011;52(1):23-30. [MEDLINE: 21148516]

Eells SJ, McKinnell JA, Miller LG. Daily cranberry prophylaxis to prevent recurrent urinary tract infections may be beneficial in some populations of women . Clinical Infectious Diseases 2011 Jun;52(11):1393-4. [MEDLINE: 21596685]

\section{Cowan 2012 \{published data only\}}

Cowan CC, Hutchison C, Cole T, Barry SJ, Paul J, Reed NS, et al. A randomised double-blind placebo controlled trial to determine the effect of cranberry juice on decreasing the incidence of urinary symptoms and urinary tract infections in patients undergoing radiotherapy for cancer of the bladder or cervix. Clinical Oncology 2012;24(2):e31-8. [MEDLINE: 21703829]

\section{Essadi 2010 \{published data only\}}

Essadi F, Elmehashi MO. Efficacy of cranberry juice for the prevention of urinary tract infections in pregnancy [abstract]. Journal of Maternal-Fetal \& Neonatal Medicine 2010;23:378. [EMBASE: 70200859]

\section{Ferrara 2009 \{published data only\}}

Ferrara P, Romaniello L, Vitelli O, Gatto A, Serva M, Cataldi L. Cranberry juice for the prevention of recurrent urinary tract infections: a randomized controlled trial in children. Scandinavian Journal of Urology \& Nephrology 2009;43(5):369-72. [MEDLINE: 19921981]

\section{Foda 1995 \{published data only\}}

Foda MM, Middlebrook PF, Gatfield CT, Potvin G, Wells G, Schillinger JF. Efficacy of cranberry in prevention of urinary tract infection in a susceptible pediatric population. Canadian Journal of Urology 1995;2(1):98-102. [CENTRAL: CN-00433652]

\section{Haverkorn 1994 \{published data only\}}

Haverkorn MJ, Mandigers J. Reduction of bacteriuria and pyuria using cranberry juice. JAMA 1994;272(8):590. [MEDLINE: 8057506]

\section{Hess 2008 \{published data only\}}

Hess MJ, Hess, PR, Sullivan MR, Nee M, Yalla SV. Evaluation of cranberry tablets for the prevention of urinary tract infections in spinal cord injured patients with neurogenic bladder. Spinal Cord 2008;46(9):622-6. [MEDLINE: 18392039]

\section{Kontiokari 2001 \{published data only\}}

Kontiokari T, Sundqvist K, Nuutinen M, Pokka T, Koskela M, Uhari M. Randomised trial of cranberry-lingonberry juice and Lactobacillus $\mathrm{GG}$ drink for the prevention of urinary tract infections in women. BMJ 2001;322(7302):1571-3. [MEDLINE: 11431298]

Lee 2007 \{published data only\}

Lee BB, Haran MJ, Hunt LM, Simpson JM, Marial O, Rutkowski SB, et al. Spinal-injured neuropathic bladder antisepsis (SINBA) trial. Spinal Cord 2007;45(8):542-50. [MEDLINE: 17043681]

\section{Linsenmeyer 2004 \{published data only\}}

* Linsenmeyer TA, Harrison B, Oakley A, Kirshblum S, Stock JA, Millis SR. Evaluation of cranberry supplement for reduction of urinary tract infections in individuals with neurogenic bladders secondary to spinal cord injury. A prospective, double-blinded, placebo-controlled, crossover study. Journal of Spinal Cord Medicine 2004;27(1):29-34. [MEDLINE: 15156934]

McGuiness 2002 \{published data only (unpublished sought but not used)\}

McGuiness SD, Krone R, Metz LM. A double-blind, randomized, placebo-controlled trial of cranberry supplements in multiple sclerosis. Journal of Neuroscience Nursing 2002;34(1):4-7.

McMurdo 2005 \{published data only\}

* McMurdo ME, Bissett LY, Price RJ, Phillips G, Crombie IK. Does ingestion of cranberry juice reduce symptomatic urinary tract infections in older people in hospital? A double-blind, placebocontrolled trial. Age \& Ageing 2005;34(3):256-61. [MEDLINE: 15863410]

\section{McMurdo 2009 \{published data only\}}

McMurdo ME, Argo I, Phillips G, Daly F, Davey P. Cranberry or trimethoprim for the prevention of recurrent urinary tract infections? A randomized controlled trial in older women. Journal of Antimicrobial Chemotherapy 2009;63(2):389-95. [MEDLINE: 19042940]

\section{NAPRUTI Study 2011 I \{published data only\}}

Beerepoot MA, Stobberingh EE, Geerlings SE. A study of nonantibiotic versus antibiotic prophylaxis for recurrent urinarytract infections in women (the NAPRUTI study) [Onderzoek naar niet-antibiotische versus antibiotische profylaxe bij vrouwen met recidiverende urineweginfecties (de NAPRUTI-studie)]. Nederlands Tijdschrift voor Geneeskunde 2006;150(10):574-5. [MEDLINE: 16566424]

Beerepoot MA, Ter Riet G, Nys S, van der Wal WM, de Borgie CA, de Reijke TM, et al. Cranberries vs antibiotics to prevent urinary tract infections: a randomized double-blind noninferiority trial in premenopausal women. Archives of Internal Medicine 2011;171(14):1270-8. [MEDLINE: 21788542] 
Gurley BJ. Cranberries as antibiotics?: Comment on "Cranberries vs antibiotics to prevent urinary tract infections: a randomized double-blind noninferiority trial in premenopausal women" . Archives of Internal Medicine $2011 \mathrm{Jul}$ 25;171(14):1279-80. [MEDLINE: 21788543]

PACS Study 2008 \{published and unpublished data\}

Juthani-Mehta M, Perley L, Chen S, Dziura J, Gupta K. Feasibility of cranberry capsule administration and clean-catch urine collection in long-term care residents. Journal of the American Geriatrics Society 2010 Oct;58(10):2028-30. [MEDLINE: 20929476]

\section{Salo 2010 \{published and unpublished data\}}

* Salo J, Kontiokari T, Helminen M, Korppi M, Nieminen T, Pokka T, et al. Randomized trial of cranberry juice for the prevention of recurrences of urinary tract infections in children [abstract]. Clinical Microbiology \& Infection 2010;16(Suppl 2):S385-6. [EMBASE: 70195963]

Salo J, Uhari M, Helminen M, Korppi M, Nieminen T, Pokka T, et al. Cranberry juice for the prevention of recurrences of urinary tract infections in children: a randomized placebo-controlled trial. Clinical Infectious Diseases 2011;54(3):340-6. [MEDLINE: 22100577]

\section{Schlager 1999 \{published data only\}}

Schlager TA, Anderson S, Trudell J, Hendley JO. Effect of cranberry juice on bacteriuria in children with neurogenic bladder receiving intermittent catheterization. Journal of Pediatrics 1999;135(6):698-702. [MEDLINE: 10586171]

\section{Sengupta 2011 \{published data only\}}

Sengupta K, Alluri KV, Golakoti T, Gottumukkala GV, Raavi J, Kotchrlakota L, et al. A randomized, double blind, controlled, dose dependent clinical trial to evaluate the efficacy of a proanthocyanidin standardized whole cranberry (Vaccinium macrocarpon) powder on infections of the urinary tract. Current Bioactive Compounds 2011;7(1):39-46. [EMBASE: 2011201647]

\section{Stothers 2002 \{published data only\}}

* Stothers L. A randomized trial to evaluate effectiveness and cost effectiveness of naturopathic cranberry products as prophylaxis against urinary tract infection in women. Canadian Journal of Urology 2002;9(3):1558-62. [MEDLINE: 12121581]

\section{Uberos 2010 \{published data only\}}

Uberos J, Nogueras-Ocana M, Fernandez-Puentes V, RodriguezBelmonte R, Narbona-López E, Molina-Carballo A, et al. Cranberry syrup vs trimethoprim in the prophylaxis of recurrent urinary tract infections among children: a controlled trial. Open Access Journal of Clinical Trials 2012;4:31-8. [EMBASE: 2012351759]

Uberos J, Rodrguez-Belmonte R, Fernndez-Puentes V, NarbonaLpez E, Molina-Carballo A, Munoz-Hoyos A. Cranberry syrup vs. trimethoprim in the prophylaxis of recurrent urinary infection: A double-blind randomized clinical trial [abstract]. Acta Paediatrica 2010;99(Suppl 462):48. [EMBASE: 70313001]
Waites 2004 \{published data only\}

* Waites KB, Canupp KC, Armstrong S, DeVivo MJ. Effect of cranberry extract on bacteriuria and pyuria in persons with neurogenic bladder secondary to spinal cord injury. Journal of Spinal Cord Medicine 2004;27(1):35-40. [MEDLINE: 15156935]

Walker 1997 \{published data only\}

Walker EB, Barney DP, Mickelsen JN, Walton RJ, Mickelsen RA Jr. Cranberry concentrate: UTI prophylaxis. Journal of Family Practice 1997;45(2):167-8. [MEDLINE: 9267377]

Wing 2008 \{published data only\}

Wing DA, Rumney PJ, Leu SY, Zaldivar F. Comparison of urinary cytokines after ingestion of cranberry juice cocktail in pregnant subjects: a pilot study. American Journal of Perinatology 2010;27(2):137-42. [MEDLINE: 19562652]

Wing DA, Rumney PJ, Preslicka CW, Chung JH. Daily cranberry juice for the prevention of asymptomatic bacteriuria in pregnancy: a randomized, controlled pilot study. Journal of Urology 2008;180(4):1367-72. [MEDLINE: 18707726]

\section{References to studies excluded from this review}

Howell 2010 \{published data only\}

Howell AB, Botto H, Combescure C, Blanc-Potard AB, Gausa L, Matsumoto T, et al. Dosage effect on uropathogenic Escherichia coli anti-adhesion activity in urine following consumption of cranberry powder standardized for proanthocyanidin content: a multicentric randomized double blind study. BMC Infectious Diseases 2010;10:94. [MEDLINE: 20398248]

\section{Jackson 1997 \{published data only\}}

Jackson B, Hicks LE. Effect of cranberry juice on urinary $\mathrm{pH}$ in older adults. Home Healthcare Nurse 1997;15(3):199-202. [MEDLINE: 9110682]

Jass 2009 \{published data only\}

Jass J, Reid G. Effect of cranberry drink on bacterial adhesion in vitro and vaginal microbiota in healthy females. Canadian Journal of Urology 2009;16(6):4901-7. [MEDLINE: 20003665]

Lavigne 2008 \{published data only\}

Lavigne JP, Bourg G, Combescure C, Botto H, Sotto A. Invitro and in-vivo evidence of dose-dependent decrease of uropathogenic Escherichia coli virulence after consumption of commercial Vaccinium macrocarpon (cranberry) capsules. Clinical Microbiology \& Infection 2008;14(4):350-5. [MEDLINE: 18190583]

Schultz 1984 \{published data only\}

Schultz A. Efficacy of cranberry juice and ascorbic acid in acidifying the urine in multiple sclerosis subjects. Journal of Community Health Nursing 1984;1(3):159-69. [MEDLINE: 6569071]

\section{Tempera 2010 \{published data only\}}

Tempera G, Corsello S, Genovese C, Caruso FE, Nicolosi D. Inhibitory activity of cranberry extract on the bacterial adhesiveness in the urine of women: an ex-vivo study. 
International Journal of Immunopathology \& Pharmacology 2010;23(2):611-8. [MEDLINE: 20646356]

Valentova 2007 \{published data only\}

Valentova K, Stejskal D, Bednar P, Vostalova J, Cihalik C, Vecerova R, et al. Biosafety, antioxidant status, and metabolites in urine after consumption of dried cranberry juice in healthy women: a pilot double-blind placebo-controlled trial. Journal of Agricultural \& Food Chemistry 2007;55(8):3217-24. [MEDLINE: 17381122]

\section{Vidlar 2010 \{published data only\}}

Vidlar A, Vostalova J, Ulrichova J, Student V, Stejskal D, Reichenbach $\mathrm{R}$, et al. The effectiveness of dried cranberries (Vaccinium macrocarpon) in men with lower urinary tract symptoms. British Journal of Nutrition 2010;104(8):1181-9. [MEDLINE: 20804630]

\section{References to studies awaiting assessment}

\section{Afshar 2012 \{published data only\}}

Afshar K, Stothers L, Scott H, MacNeily AE. Cranberry juice for the prevention of pediatric urinary tract infection: a randomized controlled trial. Journal of Urology 2012;188(4 Suppl):1584-7. [MEDLINE: 22910239]

\section{Bonetta 2011 \{published data only\}}

Bonetta A, Derelli R, Di Pierro F. Cranberry extracts reduce urinary tract infections during radiotherapy for prostate adenocarcinoma [abstract]. Anticancer Research 2011;31(5):1849-50. [EMBASE: 70437696]

\section{NCT01079169 \{published data only\}}

NCT01079169. Evaluation of the effect of cranberry capsules on the occurrence of urinary tract infections during post-acute rehabilitation of spinal cord injured patients. www.clinicaltrials.gov/ct2/show/NCT01079169 (accessed 4 June 2013).

Stapleton 2012 \{published data only (unpublished sought but not used)\}

Stapleton AE, Dziura J, Hooton TM, Cox ME, Yarova-Yarovaya Y, Chen $\mathrm{S}$, et al. Recurrent urinary tract infection and urinary Escherichia coli in women ingesting cranberry juice daily: a randomized controlled trial . Mayo Clinic Proceedings 2012;87(2):143-50. [MEDLINE: 22305026]

\section{References to ongoing studies}

NCT00100061 \{unpublished data only\}

NCT00100061. Dose response to cranberry of women with recurrent UTIs. clinicaltrials.gov/ct2/show/NCT00100061 (accessed 11 September 2012).

\section{NCT00280592 \{unpublished data only\}}

NCT00280592. Prospective, randomized, double-blind, placebo-controlled study on parallel groups evaluating the efficacy and safety of cranberry (Vaccinium Macrocarpon) in prevention of urinary tract infections in multiple sclerosis patients. clinicaltrials.gov/ct2/show/NCT00280592 (accessed 11 September 2012).

NCT01033383 \{unpublished data only\}

NCT01033383. Pilot study: Dosing study of cranberry capsules for the prevention of bacteriuria in nursing home residents. clinicaltrials.gov/ct2/show/NCT01033383 (accessed 11 September 2012).

\section{Additional references}

\section{Epp 2010}

Epp A, Larochelle A, Lovatsis D, Walter JE, Easton W, Farrell SA, et al. Recurrent urinary tract infection. Journal of Obstetrics \& Gynaecology Canada: JOGC 2010;32(11):1082-101. [MEDLINE: 21176321]

\section{Foo 2000}

Foo LY, Lu Y, Howell AB, Vorsa N. The structure of cranberry proanthocyanidins which inhibit adherence of uropathogenic P-fimbriated Escherichia coli in vitro. Phytochemistry 2000;54(2):173-81. [MEDLINE: 10872208]

\section{Foxman 2000}

Foxman B, Gillespie B, Koopman J, Zhang L, Palin K, Tallman $\mathrm{P}$, et al. Risk factors for second urinary tract infection among college women.. American Journal of Epidemiology 2000;151(12):1194-205.

\section{Foxman 2002}

Foxman B. Epidemiology of urinary tract infections: incidence, morbidity, and economic costs. American Journal of Medicine 2002;113 Suppl 1A:5S-13S. [MEDLINE: 12113866]

\section{Giesen 2010}

Giesen L, Cousins G, Dimitrov B, van de Laar F, Fahey T. Predicting acute uncomplicated urinary tract infection in women: a systematic review of the diagnostic accuracy of symptoms and signs. BMC Family Practice 2010;11:78. [MEDLINE: 20969801]

\section{Hellstrom 1991}

Hellstrom A, Hanson E, Hansson S, Hjalmas K, Jodal U. Association between urinary symptoms at 7 years old and previous urinary tract infection. Archives of Disease in Childhood 1991;66(2):232-4. [MEDLINE: 2001110]

\section{Hopkins 1994}

Hopkins WJ, Heisley DM, Jonler M, Uehling DT. Reduction of bacteriuria and pyuria using cranberry juice. JAMA 1994;272(8):588-9. [MEDLINE: 8057504]

\section{Howell 2002}

Howell AB, Foxman B. Cranberry juice and adhesion of antibiotic-resistant uropathogens. JAMA 2002;287(23):3082-3. [MEDLINE: 12069670]

\section{Howell 2005}

Howell AB, Reed JD, Kreuger CG, Winterbottom R, Cunningham DG, Leahy M. A-type cranberry proanthocyanidins 
and uropathogenic bacterial anti-adhesion activity. Phytochemistry 2005;66(18):2281-91. [MEDLINE: 16055161]

\section{Howell 2007}

Howell AB. Bioactive compounds in cranberries and their role in prevention of urinary tract infections. Molecular Nutrition \& Food Research 2007;51(6):732-7. [MEDLINE: 17487930]

\section{Kahn 1967}

Kahn HD, Panariello VA, Saeli J, Sampson JR, Schwartz E. Effect of cranberry juice on urine. Journal of the American Dietetic Association 1967;51(3):251-4. [MEDLINE: 6035629]

\section{Katz 1994}

Katz LM. Reduction of bacteriuria and pyuria using cranberry juice. JAMA 1994;272(8):589. [MEDLINE: 8057505]

\section{Kelly 1977}

Kelly J. Clinical syndromes of urinary tract infection. Current Therapeutics 1977;38(7):15-21.

\section{Kinney 1979}

Kinney $\mathrm{AB}$, Blount $\mathrm{M}$. Effect of cranberry juice on urinary $\mathrm{pH}$. Nursing Research 1979;28(5):287-90. [MEDLINE: 38439]

\section{McLeod 1978}

McLeod DC, Nahata MC. Methenamine therapy and urine acidification with ascorbic acid and cranberry juice. American Journal of Hospital Pharmacy 1978;35(6):654. [MEDLINE: 27096]

\section{Patton 1991}

Patton JP, Nash DB, Abrutyn E. Urinary tract infection: economic considerations. Medical Clinics of North America 1991;75(2):495-513. [MEDLINE: 1996046]

\section{Prior 2010}

Prior RL, Fan E, Hongping J, Howell A, Nio C, Payne M, et al. Multi-laboratory validation of a standard method for quantifying proanthocyanidins in cranberry powders. Journal of the Science of Food \& Agriculture 2010;90(9):1473-8. [MEDLINE: 20549799]

\section{Roberts 1979}

Roberts AP, Phillips R. Bacteria causing symptomatic urinary tract infection or asymptomatic bacteriuria. Journal of Clinical Pathology 1979;32(5):492-6. [MEDLINE: 381327]

\section{Schmidt 1988}

Schmidt DR, Sobota AE. An examination of the anti-adherence activity of cranberry juice on urinary and nonurinary bacterial isolates. Microbios 1988;55(224-255):173-81. [MEDLINE: 3063927]

\section{Stapleton 1997}

Stapleton A, Stamm WE. Prevention of urinary tract infection. Infectious Disease Clinics of North America 1997;11(3):719-33. [MEDLINE: 9378932]

\section{Wang 2012}

Wang CH, Fang CC, Chen NC, Liu SS, Yu PH, Wu TY, et al. Cranberry-containing products for prevention of urinary tract infections in susceptible populations: a systematic review and meta-analysis of randomized controlled trials.. Archives of Internal Medicine 2012;172(13):988-96. [MEDLINE: 22777630]

\section{Winberg 1974}

Winberg J, Andersen HJ, Bergstrom T, Jacobsson B, Larson H, Lincoln K. Epidemiology of symptomatic urinary tract infection in childhood. Acta Paediatrica Scandinavica - Supplement 1974, (252):1-20. [MEDLINE: 4618418]

\section{Wong 1984}

Wong ES, Fennell Cl, Stamm WE. Urinary tract infection among women attending a clinic for sexually transmitted diseases. Sexually Transmitted Diseases 1984;11(1):18-23. [MEDLINE: 6546811]

\section{Zafriri 1989}

Zafriri D, Ofek I, Adar R, Pocino M, Sharon N. Inhibitory activity of cranberry juice on adherence of type 1 and type $P$ fimbriated Escherichia coli to eucaryotic cells. Antimicrobial Agents \& Chemotherapy 1989;33(1):92-8. [MEDLINE: 2653218]

\section{References to other published versions of this review \\ Jepson 1998a}

Jepson RG, Mihaljevic L, Craig J. Cranberries for preventing urinary tract infections. Cochrane Database of Systematic Reviews 1998, Issue 2.

\section{Jepson 1998b}

Jepson RG, Mihaljevic L, Craig JC. Cranberries for treating urinary tract infections. Cochrane Database of Systematic Reviews 1998, Issue 4. [DOI: 10.1002/14651858.CD001322]

\section{Jepson 2004a}

Jepson RG, Mihaljevic L, Craig J. Cranberries for preventing urinary tract infections. Cochrane Database of Systematic Reviews 2004, Issue 1. [DOI: 10.1002/14651858.CD001321.pub2]

\section{Jepson 2004b}

Jepson RG, Mihaljevic L, Craig J. Cranberries for preventing urinary tract infections. Cochrane Database of Systematic Reviews 2004, Issue 2. [DOI: 10.1002/14651858.CD001321.pub3]

\section{Jepson 2008}

Jepson RG, Craig JC. Cranberries for preventing urinary tract infections. Cochrane Database of Systematic Reviews 2008, Issue 1. [DOI: 10.1002/14651858.CD001321.pub4]

* Indicates the major publication for the study 
CHARACTERISTICS OF STUDIES

Characteristics of included studies [ordered by study ID]

Avorn 1994

$\begin{array}{ll}\text { Methods } & \text { - Study design: quasi-RCT } \\ & \text { - Power calculation: Yes } \\ & \text { Intention-to-treat analysis: No }\end{array}$

Inclusion criteria
Participants
the elderly
- Country: USA
- Not clearly stated, but participants had to be willing to ingest at least $300 \mathrm{~mL}$ of cranberry juice daily
for a 6 month period.
- Number: 192 randomised, 153 analysed
- Mean age: 78.5 years
Exclusion criteria
- Terminal disease or severe dementia; men

\begin{tabular}{|c|c|}
\hline Interventions & $\begin{array}{l}\text { Treatment group } \\
\text { - Cranberry juice cocktail: } 300 \mathrm{~mL} / \mathrm{d} \text { ( } 30 \% \text { cranberry concentrate) } \\
\text { - PAC content: NS } \\
\text { Control group } \\
\text { - Placebo beverage that looked and tasted similar but contained no cranberry juice } \\
\text { Treatment duration: } 6 \text { months }\end{array}$ \\
\hline Outcomes & $\begin{array}{l}\text { - Presence of bacteriuria (bacteria in the urine } \geq 100,000 / \mathrm{mL} \text { ) with the presence of pyuria (white cells } \\
\text { in the urine) } \\
\text { - Presence of bacteriuria } \\
\text { - Presence of bacteriuria with the presence of pyuria plus symptoms of a UTI }\end{array}$ \\
\hline Notes & $\begin{array}{l}\text { - Data were presented for } 153 \text { subjects who provided a baseline urine sample and at least one additional } \\
\text { sample after randomisation } \\
\text { - Method of obtaining urine sample: mid-stream clean-voided } \\
\text { - Definition of bacteriuria: organisms } \geq 100,000 / \mathrm{mL} \text { regardless of organism } \\
\text { - Definition of pyuria: NS } \\
\text { - Exclusions post randomisation: None }\end{array}$ \\
\hline
\end{tabular}

\section{Risk of bias}

\begin{tabular}{lll}
\hline Bias & Authors' judgement & Support for judgement \\
\hline $\begin{array}{l}\text { Random sequence genera- } \\
\text { tion (selection bias) }\end{array}$ & Low risk & $\begin{array}{l}\text { Odd versus even numbers in institutional identification number or telephone } \\
\text { number (quasi-RCT) }\end{array}$ \\
\hline $\begin{array}{l}\text { Allocation concealment } \\
\text { (selection bias) }\end{array}$ & High risk & $\begin{array}{l}\text { Inadequate, could subvert system by excluding people with certain number, or } \\
\text { include more of those with a certain number }\end{array}$ \\
\hline
\end{tabular}


Avorn 1994 (Continued)

Blinding of participants Low risk Blinding stated
and personnel (perfor-
mance bias)
All outcomes

All outcomes

$\begin{array}{lll}\text { Blinding of outcome as- } & \text { Unclear risk } & \text { NS } \\ \text { sessment (detection bias) }\end{array}$

All outcomes

Incomplete outcome data High risk

(attrition bias)

Absolute numbers not always provided; 39 patients lost to follow-up/with-

All outcomes drawn

Selective reporting (re- Low risk Primary outcome is reasonable though symptomatic would be better
porting bias)

Other bias High risk Source of funding: Research grant from Ocean Spray Cranberries, Inc.

Barbosa-Cesnik 2011

\begin{tabular}{ll}
\hline Methods & Study design: parallel RCT \\
& - Power calculation: yes \\
& - Intention-to-treat analysis: no \\
\hline
\end{tabular}

\begin{tabular}{|c|c|}
\hline Participants & $\begin{array}{l}\text { Inclusion criteria } \\
\text { - Setting: Women presenting to a health service with symptoms of UTI } \\
\text { - Country: USA } \\
\text { - Women } 18-40 \text { years, with UTI symptoms, residing in Ann Arbor next } 6 \text { months } \\
\text { - Number: } 419 \text { randomised; } 319 \text { analysed } \\
\text { - Average age: } 21 \text { years } \\
\text { - Previous UTIs: 3-4 previously; } 1 \text { in previous year } \\
\text { Exclusion criteria } \\
\text { - Antibiotics in past } 48 \text { hours; hospitalisation or catheterisation within past } 2 \text { weeks; kidney stones; di- } \\
\text { abetes; pregnancy; cranberry allergy; negative urine culture }\end{array}$ \\
\hline Interventions & $\begin{array}{l}\text { Treatment group } \\
\text { - Low calorie cranberry cocktail: } 240 \mathrm{~mL}(8 \mathrm{oz}) \text { twice a day } \\
\text { - Mean PAC: } 112 \mathrm{mg} / 240 \mathrm{~mL} \\
\text { Control group } \\
\text { - Placebo drink: same volume matched for flavour and colour } \\
\text { Treatment duration: } 6 \text { months }\end{array}$ \\
\hline Outcomes & $\begin{array}{l}\text { - Primary outcome: UTI ( } \geq 10^{3} \mathrm{cfu} / \mathrm{L} \text { of known pathogen) } \\
\text { - Secondary outcome: urinary symptoms and vaginal symptoms at day } 3,1-2 \text { weeks, and } \geq 1 \text { month }\end{array}$ \\
\hline Notes & - Compliance measured by direct questioning \\
\hline
\end{tabular}

\section{Risk of bias}


Barbosa-Cesnik 2011 (Continued)

Bias Authors' judgement Support for judgement

Random sequence genera- Low risk Computer generated

tion (selection bias)

Allocation concealment $\quad$ Low risk $\quad$ External, web based allocation
(selection bias)

Blinding of participants Low risk Placebo drink matched, participants and clinicians blinded
and personnel (perfor-
mance bias)
All outcomes

\begin{tabular}{lll}
\hline $\begin{array}{l}\text { Blinding of outcome as- } \\
\text { sessment (detection bias) } \\
\text { All outcomes }\end{array}$ & Unclear risk & NS \\
\hline $\begin{array}{l}\text { Incomplete outcome data } \\
\text { (attrition bias) } \\
\text { All outcomes }\end{array}$ & High risk & $\begin{array}{l}100 \text { participants randomised but no outcomes reported for them, they were } \\
\text { actually not eligible to be randomised since they were culture negative }\end{array}$ \\
\hline $\begin{array}{l}\text { Selective reporting (re- } \\
\text { porting bias) }\end{array}$ & Low risk & UTI is most appropriate outcome \\
\hline Other bias & & Selection bias, representative nature of consenters is questionable \\
& & Source of funding: National centre for alternative medicine at NIH
\end{tabular}

Cowan 2012

\begin{tabular}{ll} 
Methods & Study design: parallel design \\
- Power calculation: provided, assumed $20 \%$ reduction in bladder problems \\
- Intention-to-treat analysis: yes \\
\hline Participants & Inclusion criteria \\
- Setting: radiotherapy booking system used to identify patients, patients had cervical cancer or blad- \\
der cancer at 1 centre \\
- Country: UK \\
- Adults $>18$ years with cervical or bladder cancer requiring radiation therapy 128 randomised; 113 analysed (7 in placebo arm, 8 in cranberry arm) \\
Exclusion criteria: NS
\end{tabular}

\begin{tabular}{ll}
\hline Interventions & Treatment group \\
& - Cranberry juice twice/d; volume (NS); PAC (NS) \\
& Control group \\
& - Matched placebo juice twice/d; volume (NS) \\
\hline Outcomes & Urinary symptoms \\
\hline Notes & Exclusions post randomisation: 0 \\
\hline
\end{tabular}


Cowan 2012 (Continued)

Risk of bias

\begin{tabular}{|c|c|c|}
\hline Bias & Authors' judgement & Support for judgement \\
\hline $\begin{array}{l}\text { Random sequence genera- } \\
\text { tion (selection bias) }\end{array}$ & Low risk & Computer based deterministic minimisation algorithm, externally allocated \\
\hline $\begin{array}{l}\text { Allocation concealment } \\
\text { (selection bias) }\end{array}$ & Low risk & Computer algorithm generated a blinded juice pack \\
\hline $\begin{array}{l}\text { Blinding of participants } \\
\text { and personnel (perfor- } \\
\text { mance bias) } \\
\text { All outcomes }\end{array}$ & Low risk & Double blinding stated, patients blinded to treatment arm, clinicians blinded \\
\hline $\begin{array}{l}\text { Blinding of outcome as- } \\
\text { sessment (detection bias) } \\
\text { All outcomes }\end{array}$ & Unclear risk & For UTI outcome probably low risk, microbiology results independent \\
\hline $\begin{array}{l}\text { Incomplete outcome data } \\
\text { (attrition bias) } \\
\text { All outcomes }\end{array}$ & Low risk & Very little missing data \\
\hline $\begin{array}{l}\text { Selective reporting (re- } \\
\text { porting bias) }\end{array}$ & Low risk & Urinary symptoms and UTI \\
\hline Other bias & Low risk & $\begin{array}{l}\text { Source of funding: west Research Endowment fund, NHS greater Glasgow and } \\
\text { Clyde, Juice and placebo supplied by Ocean Spray }\end{array}$ \\
\hline
\end{tabular}

Essadi 2010

\begin{tabular}{ll} 
Methods & Study design: parallel RCT \\
& - Power calculation: no \\
& - Intention-to-treat analysis: no \\
\hline
\end{tabular}

Participants Inclusion criteria

- Setting: Pregnant women attending an antenatal clinic between October 2008 and October 2009

- Country: NS

- Number: 760 randomised; 544 analysed

- Age: NS

Exclusion criteria: NS

\begin{tabular}{ll}
\hline Interventions & Treatment group \\
& - Cranberry juice: $250 \mathrm{~mL} 4$ times/d \\
& Control group \\
- Water: $250 \mathrm{~mL} 4$ times/d \\
\hline Outcomes & - Primary outcome: UTI \\
& Secondary: premature delivery \\
\hline
\end{tabular}


Essadi 2010 (Continued)
Notes
- Abstract only, few details

\section{Risk of bias}

\begin{tabular}{|c|c|c|}
\hline Bias & Authors' judgement & Support for judgement \\
\hline $\begin{array}{l}\text { Random sequence genera- } \\
\text { tion (selection bias) }\end{array}$ & Unclear risk & No details \\
\hline $\begin{array}{l}\text { Allocation concealment } \\
\text { (selection bias) }\end{array}$ & Unclear risk & No details \\
\hline $\begin{array}{l}\text { Blinding of participants } \\
\text { and personnel (perfor- } \\
\text { mance bias) } \\
\text { All outcomes }\end{array}$ & High risk & No, participants could tell difference between treatment and drinking water \\
\hline $\begin{array}{l}\text { Blinding of outcome as- } \\
\text { sessment (detection bias) } \\
\text { All outcomes }\end{array}$ & Unclear risk & No details provided \\
\hline $\begin{array}{l}\text { Incomplete outcome data } \\
\text { (attrition bias) } \\
\text { All outcomes }\end{array}$ & High risk & $\begin{array}{l}\text { Loss to follow-up excluded and no best-worst case scenario analysis } \\
\text { Losses to follow-up/withdrawals/exclusions post randomisation: } 216\end{array}$ \\
\hline $\begin{array}{l}\text { Selective reporting (re- } \\
\text { porting bias) }\end{array}$ & Low risk & Appropriate outcomes \\
\hline Other bias & Unclear risk & $\begin{array}{l}\text { Too few details to know } \\
\text { Source of funding: NS }\end{array}$ \\
\hline
\end{tabular}

Ferrara 2009

$\begin{array}{ll}\text { Methods } & \text { - Study design: parallel } 3 \text { arm RCT } \\ \text { - Power calculation: no } \\ \text { - Intention-to-treat analysis: no }\end{array}$

Participants Inclusion criteria

- Setting: ambulatory paediatric nephrology clinic; single centre

- Country: Italy

- Girls 3-14 years attending an ambulatory paediatric nephrology clinic; more than 1 UTI in previous 12 months

- Number: 84 randomised; 80 analysed

- Mean age: 7.5 years

Exclusion criteria

- Structural abnormalities; deformities of the urinary tract; impaired kidney function

Interventions
\[ \begin{array}{l}\text { - Cranberry-lignoberry concentrate } \\ \circ \text { Cranberry concentrate: } 50 \mathrm{~mL} / \mathrm{d} \text { for } 6 \text { months ( } 97.5 \mathrm{~g} \text { cranberry concentrate) } \\ \circ \text { Ligonberry concentrate: } 1.7 \mathrm{~g} \text { in } 50 \mathrm{~mL} \text { water }\end{array} \]


Ferrara 2009 (Continued)

\section{- No sugar additives}

- Lactobacillus GG drink: $100 \mathrm{~mL}$ on 5 days each month for 6 months (contains $4 \times 10^{7} \mathrm{cfu} / 100 \mathrm{~mL}$ )

Control group

- No treatment

Outcomes $\begin{aligned} & \text { Symptomatic UTI (symptoms being frequency, dysuria, urgency, haematuria, nocturia, fever, back or } \\ & \text { hip pain and } \geq 10^{8} \mathrm{cfu} / \mathrm{L}\end{aligned}$
hip pain and $\geq 10^{8} \mathrm{cfu} / \mathrm{L}$

Notes Exclusions post randomisation: 0

\section{Risk of bias}

\begin{tabular}{|c|c|c|}
\hline Bias & Authors' judgement & Support for judgement \\
\hline $\begin{array}{l}\text { Random sequence genera- } \\
\text { tion (selection bias) }\end{array}$ & Low risk & Random numbers table \\
\hline $\begin{array}{l}\text { Allocation concealment } \\
\text { (selection bias) }\end{array}$ & Unclear risk & No details on how well allocation was concealed \\
\hline $\begin{array}{l}\text { Blinding of participants } \\
\text { and personnel (perfor- } \\
\text { mance bias) } \\
\text { All outcomes }\end{array}$ & High risk & No, girls knew what treatment they were taking \\
\hline $\begin{array}{l}\text { Blinding of outcome as- } \\
\text { sessment (detection bias) } \\
\text { All outcomes }\end{array}$ & Unclear risk & No details stated \\
\hline $\begin{array}{l}\text { Incomplete outcome data } \\
\text { (attrition bias) } \\
\text { All outcomes }\end{array}$ & High risk & $\begin{array}{l}\text { Those lost to follow-up were excluded, no analysis of best and worst case sce- } \\
\text { narios } \\
\text { Losses to follow-up/withdrawals: } 4\end{array}$ \\
\hline $\begin{array}{l}\text { Selective reporting (re- } \\
\text { porting bias) }\end{array}$ & Low risk & Appropriate outcome \\
\hline Other bias & Unclear risk & $\begin{array}{l}\text { Details on patients are limited, selection bias may be present } \\
\text { Source of funding: NS }\end{array}$ \\
\hline
\end{tabular}

\section{Foda 1995}

\begin{tabular}{ll}
\hline Methods & Design: Cross-over RCT \\
- Power calculation: No \\
- Intention-to-treat analysis: No \\
\hline Participants & Inclusion criteria \\
- Setting: Outpatients' residence at a distance not exceeding $150 \mathrm{~km}$ from the Children's Hospital of \\
- Eastern Ontario \\
- Country: Canada \\
- Number: 40 randomised; 21 analysed
\end{tabular}


Foda 1995 (Continued)

- Age range (mean): 1.4 to 18 years ( 9.35 years)

Exclusion criteria: NS

\begin{tabular}{|c|c|}
\hline Interventions & $\begin{array}{l}\text { Treatment group } \\
\text { - Cranberry cocktail: } 15 \mathrm{~mL} / \mathrm{kg} / \mathrm{d} \text { ( } 30 \% \text { cranberry concentrate) } \\
\text { Control group } \\
\text { - Water } \\
\text { Duration of treatment: } 6 \text { months }\end{array}$ \\
\hline Outcomes & $\begin{array}{l}\text { - Number of months of positive cultures plus a symptomatic UTI } \\
\text { - Number of months of positive cultures plus an asymptomatic UTI } \\
\text { - Side effects and compliance }\end{array}$ \\
\hline Notes & $\begin{array}{l}\text { - Exclusions post randomisation: none } \\
\text { - Method of collection urine } \\
\text { - Sterile catheter urine samples } \\
\text { - Definition of bacteriuria } \\
\circ \geq 100,000 \mathrm{cfu} / \mathrm{L} \text { of a pathogenic organism after } 24 \text { hours incubation } \\
\circ \text { Any growth in a symptomatic patient was considered significant }\end{array}$ \\
\hline
\end{tabular}

\section{Risk of bias}

\begin{tabular}{|c|c|c|}
\hline Bias & Authors' judgement & Support for judgement \\
\hline $\begin{array}{l}\text { Random sequence genera- } \\
\text { tion (selection bias) }\end{array}$ & Unclear risk & NS \\
\hline $\begin{array}{l}\text { Allocation concealment } \\
\text { (selection bias) }\end{array}$ & Unclear risk & NS \\
\hline $\begin{array}{l}\text { Blinding of participants } \\
\text { and personnel (perfor- } \\
\text { mance bias) } \\
\text { All outcomes }\end{array}$ & High risk & Unable to blind participants; blinding of physician only \\
\hline $\begin{array}{l}\text { Blinding of outcome as- } \\
\text { sessment (detection bias) } \\
\text { All outcomes }\end{array}$ & Unclear risk & NS \\
\hline $\begin{array}{l}\text { Incomplete outcome data } \\
\text { (attrition bias) } \\
\text { All outcomes }\end{array}$ & Low risk & Losses to follow-up/withdrawals: 19 \\
\hline $\begin{array}{l}\text { Selective reporting (re- } \\
\text { porting bias) }\end{array}$ & Unclear risk & Not enough detail \\
\hline Other bias & Unclear risk & $\begin{array}{l}\text { Not enough detail } \\
\text { Source of funding: NS }\end{array}$ \\
\hline
\end{tabular}


Haverkorn 1994

\begin{tabular}{|c|c|}
\hline Methods & $\begin{array}{l}\text { - Design: cross-over RCT } \\
\text { - Power calculation: no } \\
\text { - Intention-to-treat analysis: no }\end{array}$ \\
\hline Participants & $\begin{array}{l}\text { Inclusion criteria } \\
\text { - Setting: Single hospital } \\
\text { - Country: The Netherlands } \\
\text { - Number: } 38 \text { randomised; } 7 \text { analysed } \\
\text { - Mean age: } 81 \text { years } \\
\text { - Sex (M/F): } 9 / / 29 \\
\text { Exclusion criteria: NS }\end{array}$ \\
\hline Interventions & $\begin{array}{l}\text { Treatment group } \\
\text { - Cranberry juice: } 30 \mathrm{~mL} / \mathrm{d} \text { mixed with water } \\
\text { - PAC: NS } \\
\text { Control group } \\
\text { - Water: same volume as intervention } \\
\text { Duration of treatment: } 4 \text { weeks active treatment ( } 8 \text { weeks total) }\end{array}$ \\
\hline Outcomes & - Bacteriuria \\
\hline Notes & $\begin{array}{l}\text { - Exclusions post randomisation: none } \\
\text { - Method of obtaining urine sample: NS } \\
\text { - Definition of bacteriuria } \\
\circ \geq 100,000 \mathrm{cfu} \text { of one of the Enterobacteriaceae/mL of urine } \\
\text { - Report is a letter only, so very few methodological details }\end{array}$ \\
\hline
\end{tabular}

\section{Risk of bias}

\begin{tabular}{|c|c|c|}
\hline Bias & Authors' judgement & Support for judgement \\
\hline $\begin{array}{l}\text { Random sequence genera- } \\
\text { tion (selection bias) }\end{array}$ & High risk & Date of birth (odd versus even numbers) \\
\hline $\begin{array}{l}\text { Allocation concealment } \\
\text { (selection bias) }\end{array}$ & High risk & $\begin{array}{l}\text { Inadequate, able to subvert system by not enrolling some if they were to start } \\
\text { on water only }\end{array}$ \\
\hline $\begin{array}{l}\text { Blinding of participants } \\
\text { and personnel (perfor- } \\
\text { mance bias) } \\
\text { All outcomes }\end{array}$ & Unclear risk & Nothing stated and no placebo \\
\hline $\begin{array}{l}\text { Blinding of outcome as- } \\
\text { sessment (detection bias) } \\
\text { All outcomes }\end{array}$ & Unclear risk & NS \\
\hline $\begin{array}{l}\text { Incomplete outcome data } \\
\text { (attrition bias) } \\
\text { All outcomes }\end{array}$ & High risk & Losses to follow-up/withdrawals: 22 \\
\hline
\end{tabular}


Haverkorn 1994 (Continued)

Selective reporting (re- Unclear risk $\quad$ Few details, can't be certain all outcomes collected are reported porting bias)

Other bias Unclear risk Insufficient detail to be certain of study design

Source of funding: NS

Hess 2008

\begin{tabular}{ll}
\hline Methods & - Study design: cross-over RCT \\
& - Power calculation: yes \\
& - Intention-to-treat analysis: no
\end{tabular}

\begin{tabular}{ll}
\hline Inclusion criteria \\
- Setting: spinal cord injury service in Veterans Admin Hospital; single centre \\
- Country: USA \\
- Number: 57 randomised; 47 analysed \\
- Sex (M/F): all men \\
Exclusion criteria \\
- Spinal cord injury duration $<12$ mo; GFR $<30 \mathrm{~mL} / \mathrm{min} ;$ immunosuppression; current malignancy \\
\hline Interventions \\
- Creatment group \\
Control group \\
- Placebo tablet: rice flour, matched to cranberry tablet \\
\hline - Primary outcome: symptomatic UTI \\
\hline Outcomes
\end{tabular}

\section{Risk of bias}

\begin{tabular}{lll}
\hline Bias & Authors' judgement & Support for judgement \\
\hline $\begin{array}{l}\text { Random sequence genera- } \\
\text { tion (selection bias) }\end{array}$ & Unclear risk & No method reported \\
\hline $\begin{array}{l}\text { Allocation concealment } \\
\text { (selection bias) }\end{array}$ & Low risk & Concealed, managed by the pharmacy \\
\hline $\begin{array}{l}\text { Blinding of participants } \\
\text { and personnel (perfor- } \\
\text { mance bias) }\end{array}$ & Low risk & Blinding stated \\
$\begin{array}{l}\text { All outcomes } \\
\text { Blinding of outcome as- } \\
\text { sessment (detection bias) } \\
\text { All outcomes }\end{array}$ & Low risk & \\
\hline
\end{tabular}


Hess 2008 (Continued)
Incomplete outcome data
High risk
10 patients lost to follow-up and no details provided

(attrition bias)

All outcomes

\begin{tabular}{lll}
\hline $\begin{array}{l}\text { Selective reporting (re- } \\
\text { porting bias) }\end{array}$ & Low risk & Appropriate outcome \\
\hline Other bias & Low risk & No apparent additional bias \\
& & Source of funding: NS
\end{tabular}

Kontiokari 2001

\begin{tabular}{ll}
\hline Methods & Study design: parallel 3-arm RCT \\
- Power calculation: yes, but recruitment stopped before appropriate number recruited \\
- Intention-to-treat analysis: yes \\
\hline Inclusion criteria \\
- Setting: Finnish student health service; single centre \\
- Country: Finland \\
- Women who had a UTI caused by E. coli $\left(10^{5} \mathrm{cfu} / \mathrm{mL}\right.$ in clean voided MSU) and were not taking antimi- \\
crobial prophylaxis. \\
- Number: 150 randomised/analysed \\
Exclusion criteria: NS
\end{tabular}

Interventions

Treatment group 1

- Cranberry-lingonberry juice concentrate (Maija, Marli, Finland): $50 \mathrm{~mL} / \mathrm{d}$

- Cranberry concentrate: $7.5 \mathrm{~g}$

- Lingonberry concentrate: $1.7 \mathrm{~g}$

- Water: $50 \mathrm{~mL}$ with no added sugars

Treatment group 2

- Lactobacillus GG drink (Gefilus, Valio, Finland): $100 \mathrm{~mL}$ for five days a week

Control group

- No intervention

Duration of treatment: 6 months cranberry-lingonberry concentrate; 12 months lactobacillus

\begin{tabular}{ll}
\hline Outcomes & - First recurrence of symptomatic UTI \\
\hline Notes & Method of obtaining urine sample: clean voided MSU specimen \\
- Definition of bacteriuria \\
- 0 Bacterial growth $10^{5} \mathrm{cfu} / \mathrm{mL}$ \\
- Recruitment had to be stopped prematurely because the cranberry juice supplier stopped producing \\
the juice. A total of 150 women gave their informed consent and were randomly allocated into three \\
groups, 50 in each. One subject in the lactobacillus group who was taking post coital antimicrobials \\
was excluded from the analysis. \\
- Exclusions post randomisation: none
\end{tabular}


Kontiokari 2001 (Continued)

Risk of bias

\begin{tabular}{|c|c|c|}
\hline Bias & Authors' judgement & Support for judgement \\
\hline $\begin{array}{l}\text { Random sequence genera- } \\
\text { tion (selection bias) }\end{array}$ & Low risk & Tables of random numbers and block technique with block size of 6 \\
\hline $\begin{array}{l}\text { Allocation concealment } \\
\text { (selection bias) }\end{array}$ & Low risk & Sealed opaque envelopes (additional information provided by authors) \\
\hline $\begin{array}{l}\text { Blinding of participants } \\
\text { and personnel (perfor- } \\
\text { mance bias) } \\
\text { All outcomes }\end{array}$ & High risk & Participants and physicians not blinded \\
\hline $\begin{array}{l}\text { Blinding of outcome as- } \\
\text { sessment (detection bias) } \\
\text { All outcomes }\end{array}$ & Low risk & Lab staff blinded \\
\hline $\begin{array}{l}\text { Incomplete outcome data } \\
\text { (attrition bias) } \\
\text { All outcomes }\end{array}$ & Low risk & Losses to follow-up/withdrawals: 13 . Analysed drop outs and withdrawals \\
\hline $\begin{array}{l}\text { Selective reporting (re- } \\
\text { porting bias) }\end{array}$ & Low risk & Appropriate outcomes \\
\hline Other bias & Unclear risk & $\begin{array}{l}\text { Uncertain about selection bias, few details } \\
\text { Source of funding: Emil Aaltonen, Juho Vainio, and Alma and K A Snellman } \\
\text { Foundations }\end{array}$ \\
\hline
\end{tabular}

Lee 2007

$\begin{array}{ll}\text { Methods } & \text { Study design: } 4 \text { group factorial design, parallel RCT } \\ & \text { - Power calculation: yes } \\ \text { - Intention-to-treat analysis: yes }\end{array}$

Participants

Inclusion criteria

- Setting: spinal cord injuries database, predominantly community dwelling patients

- Country: Australia

- Spnal cord injured people with neurogenic bladder, bladder management with either indwelling urethral or suprapubic catheter, intermittent catheterization, or reflex voiding with or without a condom drainage divide, absence of complex urological or serious renal or hepatic pathology, not being prescribed antibiotics at the time of enrolment and absence of symptoms of a UTI at enrolment. Had to be willing to stop any intercurrent urinary antiseptics before entering the study,

- Number: 305 randomised/analysed

- Mean age: 43.5 years

- Sex: 253 males

Exclusion criteria

- Previous allergy to any of the test interventions

Interventions $\quad$ Treatment group 1


Lee 2007 (Continued)

- Methenamine hippurate: $2 \mathrm{~g}$

- Cranberry: $1600 \mathrm{mg}$

Treatment group 2

- Methenamine hippurate: $2 \mathrm{~g}$

- Cranberry placebo

Treatment group 3

- Cranberry: $1600 \mathrm{mg}$

- Methenamine hippurate placebo

Control group

- Methenamine hippurate placebo

- Cranberry placebo

Outcomes

- Symptomatic UTI: current criteria for treating patients in the spinal injured population

\section{Notes}

\section{Risk of bias}

\begin{tabular}{|c|c|c|}
\hline Bias & Authors' judgement & Support for judgement \\
\hline $\begin{array}{l}\text { Random sequence genera- } \\
\text { tion (selection bias) }\end{array}$ & Low risk & Dynamically balanced, centralized randomisation performed externally \\
\hline $\begin{array}{l}\text { Allocation concealment } \\
\text { (selection bias) }\end{array}$ & Low risk & External trial centre controlled, sent to pharmacy \\
\hline $\begin{array}{l}\text { Blinding of participants } \\
\text { and personnel (perfor- } \\
\text { mance bias) } \\
\text { All outcomes }\end{array}$ & Low risk & States all staff and participants were blinded \\
\hline $\begin{array}{l}\text { Blinding of outcome as- } \\
\text { sessment (detection bias) } \\
\text { All outcomes }\end{array}$ & Low risk & States all staff were blinded \\
\hline $\begin{array}{l}\text { Incomplete outcome data } \\
\text { (attrition bias) } \\
\text { All outcomes }\end{array}$ & Low risk & All accounted for in results \\
\hline $\begin{array}{l}\text { Selective reporting (re- } \\
\text { porting bias) }\end{array}$ & Low risk & Well described \\
\hline \multirow[t]{2}{*}{ Other bias } & Low risk & No other bias apparent, well reported study \\
\hline & & Source of funding: Motor accidents authority and Brucia Pharmaceuticals \\
\hline
\end{tabular}

\section{Linsenmeyer 2004}

\begin{tabular}{ll}
\hline Methods & - Design: Cross-over RCT \\
& - Power calculation: NS \\
& - ITT analysis: no
\end{tabular}


Linsenmeyer 2004 (Continued)
Participants
Inclusion criteria
- Setting: patients presenting to outpatient urology rehabilitation clinic; single centre
- Country: USA
- Patients with neurogenic bladders secondary to spinal cord injury
- Number: 37 randomised; 21 analysed
Exclusion criteria: NS

\begin{tabular}{ll}
\hline Interventions & Treatment group \\
• Cranberry tablets: $400 \mathrm{mg}$ standardised tablets \\
Control group \\
- Placebo \\
Duration of treatment: 9 weeks (4 weeks on each, plus one week wash out) \\
\hline Outcomes $\quad$ Urinary bacterial counts and WBC counts and the combination of bacterial and WBC counts \\
\hline Exclusions post randomisation: none \\
Method of obtaining urine sample \\
- CSU or MSU \\
Definition of bacteriuria \\
- MSU: $\geq 10,000 / \mathrm{mL}$ \\
- CSU: $>100$ cfu/mL
\end{tabular}

\section{Risk of bias}

\begin{tabular}{|c|c|c|}
\hline Bias & Authors' judgement & Support for judgement \\
\hline $\begin{array}{l}\text { Random sequence genera- } \\
\text { tion (selection bias) }\end{array}$ & Unclear risk & NS \\
\hline $\begin{array}{l}\text { Allocation concealment } \\
\text { (selection bias) }\end{array}$ & Unclear risk & NS \\
\hline $\begin{array}{l}\text { Blinding of participants } \\
\text { and personnel (perfor- } \\
\text { mance bias) } \\
\text { All outcomes }\end{array}$ & Low risk & States participants and researchers blinded \\
\hline $\begin{array}{l}\text { Blinding of outcome as- } \\
\text { sessment (detection bias) } \\
\text { All outcomes }\end{array}$ & Low risk & States researchers are blinded, assume outcomes assessors included \\
\hline $\begin{array}{l}\text { Incomplete outcome data } \\
\text { (attrition bias) } \\
\text { All outcomes }\end{array}$ & Low risk & $\begin{array}{l}\text { All patients accounted for in results and analysis; losses to follow-up/with- } \\
\text { drawals: } 16\end{array}$ \\
\hline $\begin{array}{l}\text { Selective reporting (re- } \\
\text { porting bias) }\end{array}$ & Low risk & Primary outcome is appropriate \\
\hline Other bias & Unclear risk & Some methods are vague, not a well reported study \\
\hline
\end{tabular}


McGuiness 2002

\begin{tabular}{ll}
\hline Methods & Study design: parallel RCT \\
& - Power calculation: not mentioned in methods but mentioned in discussion \\
& - ITT analysis: yes ((although percentages in results do not make sense)
\end{tabular}

Inclusion criteria
- Setting: outpatient clinic for Multiple sclerosis patients; single centre
- Country: Canada
- Multiple sclerosis diagnosis (Poser criteria), Expanded Disability Status Scale 0 - 8; consented; refrain
from cranberries during study; no indwelling or condom catheter, if intermittent catheterisation, no
more that 6 times daily; symptoms of neurogenic bladder; no current UTI
- Number: 135 randomised; 106 analysed
Exclusion criteria: NS

\begin{tabular}{ll}
\hline Interventions & Treatment group \\
- Cranberry containing tablet product (NOW Natural Foods): $8000 \mathrm{mg}$ tablet, one tablet/d \\
Control group \\
- Beetroot powder placebo tablet, identical appearance to cranberry, one tablet/d \\
Duration of treatment: 6 months \\
\hline Outcomes & Diagnosed UTI \\
\hline Notes & Results reported separately for patients with intermittent catheterisation and normal voiding, but \\
study did not mention if it was stratified for this and numbers of each in the 2 treatment groups are \\
not provided
\end{tabular}

Risk of bias

\begin{tabular}{|c|c|c|}
\hline Bias & Authors' judgement & Support for judgement \\
\hline $\begin{array}{l}\text { Random sequence genera- } \\
\text { tion (selection bias) }\end{array}$ & Unclear risk & No details of randomisation method were stated \\
\hline $\begin{array}{l}\text { Allocation concealment } \\
\text { (selection bias) }\end{array}$ & Unclear risk & No details of allocation concealment methods were stated \\
\hline $\begin{array}{l}\text { Blinding of participants } \\
\text { and personnel (perfor- } \\
\text { mance bias) } \\
\text { All outcomes }\end{array}$ & Low risk & $\begin{array}{l}\text { Title states the study was double blinded, assume this refers to participants } \\
\text { and heath care providers }\end{array}$ \\
\hline $\begin{array}{l}\text { Blinding of outcome as- } \\
\text { sessment (detection bias) } \\
\text { All outcomes }\end{array}$ & Unclear risk & $\begin{array}{l}\text { Blinding of microbiologists is assumed so culture result is likely to be unbi- } \\
\text { ased. Less certain about how objectively measured the other criteria were }\end{array}$ \\
\hline
\end{tabular}


McGuiness 2002 (Continued)

Incomplete outcome data (attrition bias)

Unclear risk

All outcomes
12 participants withdrew or were lost to follow-up but the numbers in each treatment arm were not provided

Selective reporting (re- Low risk UTI was appropriate outcomes and definition was provided
porting bias)

\begin{tabular}{|c|c|c|}
\hline Other bias & Unclear risk & $\begin{array}{l}\text { No details provided on how participants were selected and from how large the } \\
\text { group, possible selection bias }\end{array}$ \\
\hline
\end{tabular}

Source of funding: Alberta Association of Registered Nurses, American Asssociation of Neuroscience Nurses

McMurdo 2005

\begin{tabular}{ll}
\hline Methods & - Study design: parallel group \\
& - Power calculation: yes \\
& Intention-to-treat analysis: yes
\end{tabular}

\section{Participants}

Inclusion criteria

- Setting: single centre

- Country: UK (Scotland)

- 60 years or over admitted to either acute medicine for the elderly assessment or rehabilitation units for elderly people

- Number: 376 randomised and analysed

Exclusion criteria

- Mental State Questionnaire (MSQ) score < 5/10; dysphagia; symptoms of a UTI; antibiotic treatment; anticipated length of stay $<1$ week; regular drinkers of cranberry juice; presence of an in-dwelling catheter; terminal illness

- In light of a UK Committee on Safety of Medicines alert about a potential interaction between cranberry juice and warfarin which emerged during the final 8 weeks of recruitment, warfarin was added as an exclusion for that period only.

$\begin{array}{ll}\text { Interventions } & \text { Treatment group } \\ \text { - Cranberry juice: } 300 \mathrm{~mL} \\ \text { Control group } \\ \text { - Matching placebo beverage } \\ \text { Duration of treatment: } 6 \text { months }\end{array}$

Outcomes

- Time to onset of first symptomatic UTI: defined as a culture positive urine growing a single organism of $>10^{4} \mathrm{cfu} / \mathrm{mL}$ urine specimen

- Adherence to beverage drinking, courses of antibiotics prescribed, and organisms responsible for UTIS

Notes

- Exclusions post randomisation: none

- Method of obtaining urine sample: clean catch

- Definition of bacteriuria

- Only pure growths of $\geq 10^{4} \mathrm{cfu} / \mathrm{mL}$ were reported with an antibiotic sensitivity

\section{Risk of bias}


McMurdo 2005 (Continued)

\begin{tabular}{|c|c|c|}
\hline Bias & Authors' judgement & Support for judgement \\
\hline $\begin{array}{l}\text { Random sequence genera- } \\
\text { tion (selection bias) }\end{array}$ & Low risk & Stratified by gender and computer generated \\
\hline $\begin{array}{l}\text { Allocation concealment } \\
\text { (selection bias) }\end{array}$ & Low risk & Held by pharmacy, sealed numbered enveloped \\
\hline $\begin{array}{l}\text { Blinding of participants } \\
\text { and personnel (perfor- } \\
\text { mance bias) } \\
\text { All outcomes }\end{array}$ & Low risk & Blinding stated \\
\hline $\begin{array}{l}\text { Blinding of outcome as- } \\
\text { sessment (detection bias) } \\
\text { All outcomes }\end{array}$ & Low risk & Blinding stated \\
\hline $\begin{array}{l}\text { Incomplete outcome data } \\
\text { (attrition bias) } \\
\text { All outcomes }\end{array}$ & Low risk & All patients analysed and reported; Losses to follow-up/withdrawals: 115 \\
\hline $\begin{array}{l}\text { Selective reporting (re- } \\
\text { porting bias) }\end{array}$ & Low risk & Appropriate clinical outcomes \\
\hline Other bias & Low risk & $\begin{array}{l}\text { No other bias apparent, well reported study } \\
\text { Source of funding: Chief Scientist Office at the Scottish Executive Department } \\
\text { of Health. The cranberry juice and matching placebo were supplied by Ocean } \\
\text { Spray Cranberries, Inc. }\end{array}$ \\
\hline
\end{tabular}

McMurdo 2009

\begin{tabular}{ll}
\hline Methods & - Study design: parallel RCT \\
& - Power calculation: yes \\
& Intention-to-treat analysis: yes
\end{tabular}

Participants Inclusion criteria

- Setting: single centre

- Country: UK (Scotland)

- Community dwelling women $\geq 45$ years with at least 2 antibiotic treated UTIs in previous 12 months confirmed by GP, but not necessarily culture proven. Predominanty through primary care services but also from newspaper ads

- Number: 137 randomised and analysed

Exclusion criteria: NS

$\begin{array}{ll}\text { Interventions } & \text { Treatment group } \\ \text { - Cranberry tablet: } 500 \mathrm{mg} \\ \text { Control group } \\ \text { - TMP tablet: } 100 \mathrm{mg} \\ \text { Matched tablets with over-coating }\end{array}$


McMurdo 2009 (Continued)

Outcomes • Symptomatic UTI

\section{Notes}

\section{Risk of bias}

\begin{tabular}{|c|c|c|}
\hline Bias & Authors' judgement & Support for judgement \\
\hline $\begin{array}{l}\text { Random sequence genera- } \\
\text { tion (selection bias) }\end{array}$ & Low risk & $\begin{array}{l}\text { Off site by DHP Pharma in Powys,UK, blocks of } 4 \text { using Prisym PFW clin soft- } \\
\text { ware to generate random numbers }\end{array}$ \\
\hline $\begin{array}{l}\text { Allocation concealment } \\
\text { (selection bias) }\end{array}$ & Low risk & Externally managed, not able to be influenced \\
\hline $\begin{array}{l}\text { Blinding of participants } \\
\text { and personnel (perfor- } \\
\text { mance bias) } \\
\text { All outcomes }\end{array}$ & Low risk & Blinding stated \\
\hline $\begin{array}{l}\text { Blinding of outcome as- } \\
\text { sessment (detection bias) } \\
\text { All outcomes }\end{array}$ & Low risk & Stated as blinded \\
\hline $\begin{array}{l}\text { Incomplete outcome data } \\
\text { (attrition bias) } \\
\text { All outcomes }\end{array}$ & Low risk & All patients accounted for; losses to follow-up/withdrawals: 17 \\
\hline $\begin{array}{l}\text { Selective reporting (re- } \\
\text { porting bias) }\end{array}$ & Low risk & Symptomatic UTI is most appropriate \\
\hline Other bias & Low risk & $\begin{array}{l}\text { Well reported, no other bias apparent } \\
\text { Source of funding: Moulton charitable foundation }\end{array}$ \\
\hline
\end{tabular}

\section{NAPRUTI Study 2011 I}

\begin{tabular}{ll}
\hline Methods & Study design: parallel RCT \\
- & Power calculation: yes \\
- Intention-to-treat analysis: no & Inclusion criteria \\
\hline Participants & Setting: 10 centres \\
- Country: The Netherlands & Premenopausal women $>18$ years with at least 3 symptomatic UTIs in the year prior to enrolment, \\
& self reported. Recruited through direct advertising and primary care facilities as well as secondary and \\
& tertiary level hospital referrals \\
- & Number: 221 randomised; 200 analysed (for repeat symptomatic UTI) \\
Exclusion criteria & Symptoms of UTI at inclusion, use of antibiotics or cranberry in previous 2 weeks, relevant interaction \\
& with other medications or contraindications for TMP-SMX or cranberries, pregnancy, breastfeeding or \\
& renal transplantation \\
\hline Treatment group
\end{tabular}


- Cranberry extract: 500 mg twice daily (9.1 mg/g type A PAC)

- Placebo tablet: 1 tablet at night

Control group

- TMP-SMX: $480 \mathrm{mg}$ at night

- Placebo tablet: 1 tablet twice daily

Placebo and active tablets were identical

Duration of treatment: 12 months

\begin{tabular}{ll}
\hline Outcomes & Primary outcome: mean number of clinically defined UTIs over 12 months \\
& - Secondary outcome: proportion of patients with at least 1 symptomatic UTI, median time to sympto- \\
& matic UTI, bacterial resistance to active treatment \\
\hline Notes & Email correspondence from Marielle Beerepoot on 5 June 2012 provided the actual numbers of par- \\
& ticipants in each arm who experienced a UTI \\
- Exclusions post randomisation: 14
\end{tabular}

\section{Risk of bias}

\begin{tabular}{|c|c|c|}
\hline Bias & Authors' judgement & Support for judgement \\
\hline $\begin{array}{l}\text { Random sequence genera- } \\
\text { tion (selection bias) }\end{array}$ & Low risk & $\begin{array}{l}\text { Generation of the allocation list was computer-aided block randomisation } \\
\text { with stratification by centre and presence of complicating host factors. Pre- } \\
\text { pared in advance by coordinating centre, unlikely to be influenced by clini- } \\
\text { cians/researchers on site }\end{array}$ \\
\hline $\begin{array}{l}\text { Allocation concealment } \\
\text { (selection bias) }\end{array}$ & Low risk & External to clinical site \\
\hline $\begin{array}{l}\text { Blinding of participants } \\
\text { and personnel (perfor- } \\
\text { mance bias) } \\
\text { All outcomes }\end{array}$ & Low risk & Matched drug and dose regimen \\
\hline $\begin{array}{l}\text { Blinding of outcome as- } \\
\text { sessment (detection bias) } \\
\text { All outcomes }\end{array}$ & Low risk & Stated \\
\hline $\begin{array}{l}\text { Incomplete outcome data } \\
\text { (attrition bias) } \\
\text { All outcomes }\end{array}$ & High risk & $\begin{array}{l}\text { Considerable loss to follow up, no best and worst case scenario analysis. } \\
\text { Losses to follow-up/withdrawals: } 70 \text { without follow-up at } 12 \text { months }\end{array}$ \\
\hline $\begin{array}{l}\text { Selective reporting (re- } \\
\text { porting bias) }\end{array}$ & Low risk & Many outcomes reported, clinically appropriate \\
\hline Other bias & Low risk & $\begin{array}{l}\text { Appears to be a representative sample } \\
\text { Source of funding: Netherland Organisation for health research and develop- } \\
\text { ment }\end{array}$ \\
\hline
\end{tabular}

\section{PACS Study 2008}

\begin{tabular}{ll}
\hline Methods & - Study design: 3-arm parallel RCT \\
& - Power calculation: no
\end{tabular}


PACS Study 2008 (Continued)

- Intention-to-treat analysis: appears all were included

\begin{tabular}{ll}
\hline Participants & Setting: 4 dementia units \\
- Country: USA & Elderly mean and women $>60$ years of age with dementia and a resident of a nursing home or assisted \\
& living facility for $>30$ days \\
- Number: 56 randomised and analysed
\end{tabular}

\begin{tabular}{ll}
\hline Interventions & Treatment group 1 \\
- Cranberry capsule: $1 \times 650 \mathrm{mg}$ once daily \\
Treatment group 2 \\
- Cranberry capsule: $1 \times 650 \mathrm{mg}$ twice daily \\
Control group \\
- No treatment \\
- Number of urine cultures collected \\
- Number of participants with E.coli isolated from urine culture \\
- Number of participants with $>100,000 \mathrm{cfu} / \mathrm{mL}$ if any organism
\end{tabular}

Notes

- Details from clinical trials register, not from a published paper

- Designed as a feasibility pilot for a larger study, wanted to determine if collecting urine was feasible

\section{Risk of bias}

\begin{tabular}{|c|c|c|}
\hline Bias & Authors' judgement & Support for judgement \\
\hline $\begin{array}{l}\text { Random sequence genera- } \\
\text { tion (selection bias) }\end{array}$ & Unclear risk & No details on this aspect \\
\hline $\begin{array}{l}\text { Allocation concealment } \\
\text { (selection bias) }\end{array}$ & Unclear risk & Open label study, could be possible to subvert randomisation \\
\hline $\begin{array}{l}\text { Blinding of participants } \\
\text { and personnel (perfor- } \\
\text { mance bias) } \\
\text { All outcomes }\end{array}$ & High risk & Open label study \\
\hline $\begin{array}{l}\text { Blinding of outcome as- } \\
\text { sessment (detection bias) } \\
\text { All outcomes }\end{array}$ & High risk & Open label \\
\hline $\begin{array}{l}\text { Incomplete outcome data } \\
\text { (attrition bias) } \\
\text { All outcomes }\end{array}$ & Unclear risk & $\begin{array}{l}\text { Expected number of urine samples was less than expected. } \\
\text { Losses to follow-up/withdrawals: } 2 \text { lost and } 28 \text { did not complete treatment }\end{array}$ \\
\hline $\begin{array}{l}\text { Selective reporting (re- } \\
\text { porting bias) }\end{array}$ & Unclear risk & Outcomes are about feasibility not efficacy \\
\hline Other bias & Unclear risk & $\begin{array}{l}\text { Many details missing or poorly detailed } \\
\text { Source of funding: NS }\end{array}$ \\
\hline
\end{tabular}


Salo 2010

\begin{tabular}{ll}
\hline Methods & Study design: parallel RCT \\
- Power calculation: provided, justified, although highly optimistic \\
- Intention-to-treat analysis: no, 8 excluded
\end{tabular}

\section{Risk of bias}

\begin{tabular}{|c|c|c|}
\hline Bias & Authors' judgement & Support for judgement \\
\hline $\begin{array}{l}\text { Random sequence genera- } \\
\text { tion (selection bias) }\end{array}$ & Low risk & Block size 4 , externally managed \\
\hline $\begin{array}{l}\text { Allocation concealment } \\
\text { (selection bias) }\end{array}$ & Low risk & Sealed envelopes \\
\hline $\begin{array}{l}\text { Blinding of participants } \\
\text { and personnel (perfor- } \\
\text { mance bias) } \\
\text { All outcomes }\end{array}$ & Low risk & Double blind, states clinician and parents blind \\
\hline $\begin{array}{l}\text { Blinding of outcome as- } \\
\text { sessment (detection bias) } \\
\text { All outcomes }\end{array}$ & Unclear risk & Not specifically stated \\
\hline $\begin{array}{l}\text { Incomplete outcome data } \\
\text { (attrition bias) } \\
\text { All outcomes }\end{array}$ & Low risk & $\begin{array}{l}\text { Few missing data } \\
\text { Losses to follow-up/withdrawals: } 27 \text { drop outs (16 in cranberry arm, } 11 \text { in } \\
\text { placebo group) } \\
\text { Exclusions post randomisation: } 8\end{array}$ \\
\hline $\begin{array}{l}\text { Selective reporting (re- } \\
\text { porting bias) }\end{array}$ & Low risk & Most appropriate outcome used \\
\hline Other bias & Low risk & $\begin{array}{l}\text { Well reported study } \\
\text { Source of funding: Paivikki and Sakari Sohlberg Foundation, Foundation for } \\
\text { Paediatric research, Paulo Foundation, Ocena Spray }\end{array}$ \\
\hline
\end{tabular}


Schlager 1999

\begin{tabular}{|c|c|}
\hline Methods & $\begin{array}{l}\text { - Study design: cross-over RCT } \\
\text { - Power calculation: no } \\
\text { - Intention-to-treat analysis: yes }\end{array}$ \\
\hline Participants & $\begin{array}{l}\text { Inclusion criteria } \\
\text { - Setting: single centre } \\
\text { - Country: USA } \\
\text { - Neuropathic bladder and managed by clean intermittent catheterisation; lived at home, had normal } \\
\text { findings on renal ultrasonography and voided cystourethrogram, and lived within a } 1 \text { hour drive of } \\
\text { the hospital. } \\
\text { - Number: } 15 \text { randomised and analysed } \\
\text { - Age range: } 2-18 \text { years } \\
\text { Exclusion criteria: NS }\end{array}$ \\
\hline Interventions & $\begin{array}{l}\text { Treatment group } \\
\text { - Cranberry juice cocktail: } 300 \mathrm{~mL} / \mathrm{d} \text { ( } 30 \% \text { cranberry concentrate) } \\
\text { Control group } \\
\text { - Placebo beverage: looked and tasted similar but contained no cranberry juice } \\
\text { Duration of treatment: } 3 \text { months cranberry juice; } 3 \text { months placebo }\end{array}$ \\
\hline Outcomes & $\begin{array}{l}\text { - Presence of bacteriuria } \\
\text { - Symptomatic UTI }\end{array}$ \\
\hline Notes & $\begin{array}{l}\text { - Method of obtaining urine sample } \\
\text { - } \mathrm{CSU} \\
\text { - Definition of symptomatic bacteriuria } \\
\circ \text { Defined as bacteriuria with fever, abdominal pain, change in continence pattern, or change in } \\
\text { colour or odour of urine } \\
\text { - Definition of bacteriuria } \\
\circ \geq 100,000 / \mathrm{mL}\end{array}$ \\
\hline
\end{tabular}

\section{Risk of bias}

\begin{tabular}{lll}
\hline Bias & Authors' judgement & Support for judgement \\
\hline $\begin{array}{l}\text { Random sequence genera- } \\
\text { tion (selection bias) }\end{array}$ & Unclear risk & No details provided, states only "randomly assigned" \\
\hline $\begin{array}{l}\text { Allocation concealment } \\
\text { (selection bias) }\end{array}$ & Low risk & Adequate, randomly assigned by research pharmacist \\
\hline $\begin{array}{l}\text { Blinding of participants } \\
\text { and personnel (perfor- } \\
\text { mance bias) }\end{array}$ & Low risk & Stated as double blinded \\
$\begin{array}{l}\text { All outcomes } \\
\text { Blinding of outcome as- } \\
\text { sessment (detection bias) } \\
\text { All outcomes }\end{array}$ & Low risk & Culture results not available to investigators during the study \\
\hline
\end{tabular}


Schlager 1999 (Continued)
Incomplete outcome data
Low risk
All children and results accounted for
(attrition bias)

All outcomes

\begin{tabular}{lll}
\hline $\begin{array}{l}\text { Selective reporting (re- } \\
\text { porting bias) }\end{array}$ & Low risk & Symptomatic UTI reported as appropriate \\
\hline Other bias & Low risk & Nothing apparent \\
& $\begin{array}{l}\text { Source of funding: Grants from Spinal Cord Research Foundation and the } \\
\text { Pendleton Pediatric Infectious Disease Research Laboratory }\end{array}$ \\
\hline
\end{tabular}

\section{Sengupta 2011}

$\begin{array}{ll}\text { Methods } & \text { Study design: 3-arm parallel RCT } \\ \text { - Power calculation: no } \\ \text { - Intention-to-treat analysis: no, } 3 \text { post randomisation drop outs were not analysed }\end{array}$

Inclusion criteria
- Setting: uncertain, possibly single centre
- Country: India
- Females with a history of recurrent UTIs, with dysuria, frequency, blood in urine or pain in suprapubic
region and negative pregnancy test
- Number: 60 randomised and analysed
Exclusion criteria
- Antibiotics in past 48 hours; catheterized within last 2 weeks; diabetes; cardiovascular disease;
pyelonephritis; kidney stones

Interventions

Treatment group 1

- Cranberry: $500 \mathrm{mg} / \mathrm{d}$

Treatment group 2

- Cranberry: $1000 \mathrm{mg} / \mathrm{d}$

Control group

- No treatment

1.5\% PAC, Decas Botanical Synergies

Outcomes - Symptomatic UTI with $>10^{4} \mathrm{cfu} / \mathrm{mL}$ E.coli pure growth

\section{Notes}

\section{Risk of bias}

\begin{tabular}{lll}
\hline Bias & Authors' judgement & Support for judgement \\
\hline $\begin{array}{l}\text { Random sequence genera- } \\
\text { tion (selection bias) }\end{array}$ & Low risk & Computer generated \\
\hline
\end{tabular}


Sengupta 2011 (Continued)

Allocation concealment Low risk Externally managed, sealed envelopes opened in order; completed by inde(selection bias) pendent person

Blinding of participants and personnel (perfor-

High risk

Participants were not blinded

mance bias)

All outcomes

\section{Blinding of outcome as-}

Unclear risk

Uncertain if researchers or assessors were blind to allocated treatment sessment (detection bias)

All outcomes

\begin{tabular}{|c|c|c|}
\hline $\begin{array}{l}\text { Incomplete outcome data } \\
\text { (attrition bias) } \\
\text { All outcomes }\end{array}$ & Unclear risk & $\begin{array}{l}\text { Nothing apparent but unclear in the report } \\
\text { Exclusions post randomisation: } 3\end{array}$ \\
\hline
\end{tabular}

Selective reporting (re- Low risk Symptomatic culture proven UTI is most appropriate outcome

porting bias)

$\begin{array}{ll}\text { Other bias } & \text { Unclear risk } \\ & \text { Source of funding: NS }\end{array}$

Source of funding: NS

\section{Stothers 2002}

\begin{tabular}{ll}
\hline Methods & Study design: parallel RCT \\
& - Power calculations: no \\
& Intention-to-treat analysis: yes
\end{tabular}

Inclusion criteria
Participants $\quad$ Setting: single centre
- Country: Canada
- At least two symptomatic, single-organism, culture positive UTIs in the previous calendar year, but
were currently free of UTI on urinalysis and culture; sexually active women
- Number: 150 randomised and analysed
Exclusion criteria
- Neurogenic bladder dysfunction; insulin-dependent diabetes; immunosuppressive disease; steroid
use; intermittent or indwelling catheterisation

Treatment group 1

- Placebo juice + cranberry tablets: 1:30 parts concentrated juice, two times/d

Treatment group 2

- Cranberry juice: $250 \mathrm{~mL}$ three times/d

- Placebo tablets

Control group

- Placebo juice: filtered water with food colouring $+20 \mathrm{~mL}$ pineapple juice

- Placebo tablets 
Stothers 2002 (Continued)

Duration of treatment: one year

\begin{tabular}{ll}
\hline Outcomes & $>50 \%$ decrease in symptomatic UTI/y (symptoms $+\geq 100,000$ single organisms $/ \mathrm{mL}$ ) \\
- & $>50 \%$ decrease in annual antibiotic consumption \\
\hline Notes & Costs effectiveness of treatment \\
& Method of obtaining urine sample \\
& $\circ \mathrm{CSU}$ \\
& Definition of bacteriuria \\
& $\circ$ Bacteria in the urine $\geq 100,000 / \mathrm{mL}$ \\
\hline
\end{tabular}

\section{Risk of bias}

\begin{tabular}{|c|c|c|}
\hline Bias & Authors' judgement & Support for judgement \\
\hline $\begin{array}{l}\text { Random sequence genera- } \\
\text { tion (selection bias) }\end{array}$ & Low risk & $\begin{array}{l}\text { Blocks of } 10 \text { to one arm of the study, computer generated (additional informa- } \\
\text { tion provided by authors) }\end{array}$ \\
\hline $\begin{array}{l}\text { Allocation concealment } \\
\text { (selection bias) }\end{array}$ & Low risk & Adequate, pharmacist dispensed allocated treatment packages \\
\hline $\begin{array}{l}\text { Blinding of participants } \\
\text { and personnel (perfor- } \\
\text { mance bias) } \\
\text { All outcomes }\end{array}$ & Low risk & States double blind \\
\hline $\begin{array}{l}\text { Blinding of outcome as- } \\
\text { sessment (detection bias) } \\
\text { All outcomes }\end{array}$ & Low risk & $\begin{array}{l}\text { Researchers blind and microbiology laboratory probably blind when interpret- } \\
\text { ing plated results }\end{array}$ \\
\hline $\begin{array}{l}\text { Incomplete outcome data } \\
\text { (attrition bias) } \\
\text { All outcomes }\end{array}$ & Low risk & $\begin{array}{l}\text { All patients accounted for in results } \\
\text { Losses to follow-up/withdrawals: } 2 \text { patients in the cranberry juice arm } \\
\text { dropped out }\end{array}$ \\
\hline $\begin{array}{l}\text { Selective reporting (re- } \\
\text { porting bias) }\end{array}$ & Low risk & UTI appropriate outcome \\
\hline Other bias & Low risk & $\begin{array}{l}\text { None apparent } \\
\text { Source of funding: NS }\end{array}$ \\
\hline
\end{tabular}

\section{Uberos 2010}

\begin{tabular}{ll}
\hline Methods & Study design: parallel RCT \\
- & Power calculation: no \\
- Intention-to-treat analysis: yes, and also survival analysis in which appearance of the event (UTI) was \\
sufficient cause for ending the follow-up period
\end{tabular}


Uberos 2010 (Continued)

- Number: 198 randomised; 192 analysed

\begin{tabular}{ll}
\hline Interventions & Treatment group \\
& - Cranberry syrup: $0.2 \mathrm{~mL} / \mathrm{kg}$ (Urell, Pharmatoka) \\
& Control group \\
& - TMP: $8 \mathrm{mg} / \mathrm{kg}$ \\
\hline Outcomes & U UTI \\
\hline Notes & Published first as an abstract, more recently as a full report
\end{tabular}

\section{Risk of bias}

\begin{tabular}{lll}
\hline Bias & Authors' judgement & Support for judgement \\
\hline $\begin{array}{l}\text { Random sequence genera- } \\
\text { tion (selection bias) }\end{array}$ & Low risk & Computer and ID card \\
\hline $\begin{array}{l}\text { Allocation concealment } \\
\text { (selection bias) }\end{array}$ & Low risk & Method stated \\
\hline $\begin{array}{l}\text { Blinding of participants } \\
\text { and personnel (perfor- } \\
\text { mance bias) }\end{array}$ & Low risk & States double blinding \\
\begin{tabular}{l} 
All outcomes \\
\hline
\end{tabular} & & \\
\hline
\end{tabular}

\begin{tabular}{|c|c|c|}
\hline $\begin{array}{l}\text { Blinding of outcome as- } \\
\text { sessment (detection bias) } \\
\text { All outcomes }\end{array}$ & Unclear risk & Possibly, uncertain who double blind refers to \\
\hline $\begin{array}{l}\text { Incomplete outcome data } \\
\text { (attrition bias) } \\
\text { All outcomes }\end{array}$ & Low risk & Losses to follow-up/withdrawals: 3 in each group (six in total) \\
\hline $\begin{array}{l}\text { Selective reporting (re- } \\
\text { porting bias) }\end{array}$ & Low risk & Symptomatic UTI is most appropriate \\
\hline Other bias & Unclear risk & $\begin{array}{l}\text { Due to problems during the randomisation process, } 75 \text { patients were assigned } \\
\text { to receive cranberry syrup and } 117 \text { to receive TMP. However, blinding to treat- } \\
\text { ment was maintained. } \\
\text { Source of funding: Carlos III Institute of Health for Clinical Research, Madrid, } \\
\text { Spain }\end{array}$ \\
\hline
\end{tabular}

Waites 2004

\begin{tabular}{ll}
\hline Methods & Study design: parallel RCT \\
& - Power calculations: no \\
\hline Participants & Intention-to-treat analysis: no \\
\hline Inclusion criteria \\
- Setting: single centre \\
- Country: USA
\end{tabular}


Waites 2004 (Continued)

- Community residing men and women at least one year post spinal cord injury, age 16 years or older, neurogenic bladder managed by clean intermittent catheterization or external collection device, no systemic antimicrobials or urinary acidifying agents taken within 7 days, no current fever and chills suggestive of acute symptomatic UTI, and agreement not to ingest and cranberry-containing products whilst participation in the clinical study. Baseline urine culture demonstrating at least $10^{5} \mathrm{cfu} / \mathrm{mL}$

- Number: 74 randomised; 48 analysed

\begin{tabular}{|c|c|}
\hline Interventions & $\begin{array}{l}\text { Treatment group } \\
\text { - Concentrated cranberry extract: } 2 \mathrm{~g} \text { in capsule form } \\
\text { Control group } \\
\text { - Placebo capsule } \\
\text { Duration of treatment: } 6 \text { months }\end{array}$ \\
\hline Outcomes & $\begin{array}{l}\text { - Baseline urinalysis and cultures were performed at the time of the initial clinic visit and monthly for } \\
6 \text { months }\end{array}$ \\
\hline Notes & $\begin{array}{l}\text { - Microbiologic data were evaluated using analysis of variance with repeated measures. } \\
\text { - Method of obtaining urine sample } \\
\circ \mathrm{CSU} \text { or clean catch } \\
\text { - Definition of bacteriuria } \\
\circ \geq 100,000 / \mathrm{mL}\end{array}$ \\
\hline
\end{tabular}

\section{Risk of bias}

\begin{tabular}{|c|c|c|}
\hline Bias & Authors' judgement & Support for judgement \\
\hline $\begin{array}{l}\text { Random sequence genera- } \\
\text { tion (selection bias) }\end{array}$ & Unclear risk & No details about random sequence methods were reported \\
\hline $\begin{array}{l}\text { Allocation concealment } \\
\text { (selection bias) }\end{array}$ & Unclear risk & Uncertain of the process of treatment allocation, no details were reported \\
\hline $\begin{array}{l}\text { Blinding of participants } \\
\text { and personnel (perfor- } \\
\text { mance bias) } \\
\text { All outcomes }\end{array}$ & Low risk & Patients and clinicians were blind to treatment allocation \\
\hline $\begin{array}{l}\text { Blinding of outcome as- } \\
\text { sessment (detection bias) } \\
\text { All outcomes }\end{array}$ & Unclear risk & $\begin{array}{l}\text { Probably likely that microbiology staff assessing culture results were blind to } \\
\text { treatment, but this wasn't stated }\end{array}$ \\
\hline $\begin{array}{l}\text { Incomplete outcome data } \\
\text { (attrition bias) } \\
\text { All outcomes }\end{array}$ & High risk & 26 withdrawals out of 74 participants had no data on outcomes \\
\hline $\begin{array}{l}\text { Selective reporting (re- } \\
\text { porting bias) }\end{array}$ & Low risk & The primary outcome was symptomatic UTI which is appropriate \\
\hline Other bias & Unclear risk & $\begin{array}{l}\text { Few details on how patients were identified, possible selection bias } \\
\text { Source of funding: NS, but Cranberry capsules were provided by Aim This Way, } \\
\text { Cambridge, Massachusetts. }\end{array}$ \\
\hline
\end{tabular}


Walker 1997

\begin{tabular}{|c|c|}
\hline Methods & $\begin{array}{l}\text { - Study design: cross-over RCT } \\
\text { - Power calculation: no } \\
\text { - Intention-to-treat analysis: no }\end{array}$ \\
\hline Participants & $\begin{array}{l}\text { Inclusion criteria } \\
\text { - Setting: single centre } \\
\text { - Country: USA } \\
\text { - Non pregnant, sexually active women between the ages of } 18 \text { and } 45 \text { years with a recurrent UTI ( } 4 \text { UTIS } \\
\text { during the past year or at least one during the previous } 3 \text { months); sexually active women } \\
\text { - Number: } 19 \text { randomised; } 10 \text { analysed } \\
\text { - Age range (median): } 28-44 \text { years ( } 37 \text { ) } \\
\text { Exclusion criteria: NS }\end{array}$ \\
\hline Interventions & $\begin{array}{l}\text { Treatment group } \\
\text { - Cranberry capsules: } 400 \mathrm{mg} \text { of cranberry solids (number/d NS) } \\
\text { Control group } \\
\text { - Placebo capsule } \\
\text { Duration of treatment: each patient had } 3 \text { months of active treatment and } 3 \text { months placebo }\end{array}$ \\
\hline Outcomes & - Symptomatic UTI \\
\hline Notes & $\begin{array}{l}\text { - Method of obtaining urine sample: NS } \\
\text { - Dedfinition of symptomatic UTI } \\
\text { - Women notified the physician and then submitted a urine sample (method: NS) } \\
\text { - To ensure a consistent entry point into the study, each participant was held in a queue until suffering } \\
\text { a symptomatic UTI } \\
\text { - Each subsequent UTI episode was treated with antibiotics }\end{array}$ \\
\hline
\end{tabular}

\section{Risk of bias}

\begin{tabular}{lll}
\hline Bias & Authors' judgement & Support for judgement \\
\hline $\begin{array}{l}\text { Random sequence genera- } \\
\text { tion (selection bias) }\end{array}$ & Unclear risk & NS \\
\hline $\begin{array}{l}\text { Allocation concealment } \\
\text { (selection bias) }\end{array}$ & Low risk & States clinicians unaware of allocation \\
\hline $\begin{array}{l}\text { Blinding of participants } \\
\text { and personnel (perfor- } \\
\text { mance bias) } \\
\text { All outcomes }\end{array}$ & Low risk & States double blinding and opaque matching bottles \\
\hline $\begin{array}{l}\text { Blinding of outcome as- } \\
\text { sessment (detection bias) } \\
\text { All outcomes }\end{array}$ & Low risk & \\
\hline $\begin{array}{l}\text { Incomplete outcome data } \\
\text { (attrition bias) } \\
\begin{array}{l}\text { All outcomes } \\
\hline\end{array}\end{array}$ & High risk & $\begin{array}{l}\text { States double blind, likely that culture results read without knowledge of } \\
\text { treatment arm }\end{array}$ \\
\hline
\end{tabular}


Walker 1997 (Continued)

Selective reporting (re- Low risk $\quad$ Symptomatic UTI most appropriate outcome
porting bias)

\begin{tabular}{ll}
\hline Other bias & Unclear risk \\
& Source of funding: NS (capsules provided by Solaray, Inc)
\end{tabular}

Wing 2008

\begin{tabular}{ll}
\hline Methods & Study design: 3 -arm RCT \\
& - Power calculation: no, feasibility pilot \\
& - Intention-to-treat analysis: yes
\end{tabular}

Inclusion criteria
- Setting: 2 centres
- Country: USA
- Women $<16$ weeks gestation presenting for prenatal care at 1 of 2 centres
- Number: 188 randomised and analysed
Exclusion criteria
- Underlying medical conditions (e.g. diabetes mellitus, kidney failure, sickle cell disease, chronic hy-
pertension, chronic kidney disease) previous or current antimicrobial therapy; known urological ab-
normalities

Interventions

Treatment group 1

- Cranberry juice: $240 \mathrm{~mL}$ at breakfast, placebo juice at other meals

Treatment group 2

- Cranberry drink: $240 \mathrm{~mL}, 3$ times/d, reducing to twice/d after 52 enrolments because not well tolerated

Control group

- Placebo: 3 daily doses of matched juice product
Outcomes Primary outcome: asymptomatic bacteriuria, $>10^{8} \mathrm{cfu}$ of a single organism and no symptoms
- Secondary outcomes
- Symptomatic bacteriuria, $>10^{8} \mathrm{cfu}$ of single organism and dysuria or frequency or urgency
- Pyelonephritis, culture as above, + flak pain, fever $>100.4^{\circ} \mathrm{F}$, chills nausea, vomiting
- At least 1 UTI, UTI due to enteric bacteria,
- Pregnancy outcomes: preterm delivery, spontaneous vaginal delivery, instrumental vaginal deliv- ery, caesarean/caesarean hysterectomy, mean birth weight, low birth weight, 1 min Apgar $<7,5$ min Apgar $<9$, admission to NICU, tolerability and compliance

\section{Notes}

\section{Risk of bias}

\section{Bias}

\section{Authors' judgement Support for judgement}

Random sequence genera- Low risk tion (selection bias)

Computer generated randomisation table, stratified by site 
Wing 2008 (Continued)

\begin{tabular}{l}
$\begin{array}{l}\text { Allocation concealment } \\
\text { (selection bias) }\end{array} \quad$ Low risk Treatment options were not known to researchers \\
\hline
\end{tabular}

Blinding of participants Low risk States all were blinded

and personnel (perfor-

mance bias)

All outcomes

$\begin{array}{ll}\text { Blinding of outcome as- } & \text { Low risk }\end{array}$

(detection bias)

All outcomes

\begin{tabular}{|c|c|c|}
\hline $\begin{array}{l}\text { Incomplete outcome data } \\
\text { (attrition bias) } \\
\text { All outcomes }\end{array}$ & Low risk & $\begin{array}{l}\text { Data are well reported for completeness } \\
\text { Losses to follow-up/withdrawals: } 73 \text { withdrawals }\end{array}$ \\
\hline
\end{tabular}

\begin{tabular}{lll}
\hline $\begin{array}{l}\text { Selective reporting (re- } \\
\text { porting bias) }\end{array}$ & Low risk & Appropriate outcomes \\
\hline Other bias & Low risk & Details suggest free of bias, although selection methods a little unclear \\
& Source of funding: NS
\end{tabular}

Source of funding: NS

cfu - colony forming units; CSU - catheter specimen of urine; GFR - glomerular filtration rate; ITT - intention-to-treat; MSU - midstream urine; NS - not stated; PAC - proanthocyanidin; SMP - sulfamethoxazole; TMP - trimethoprim; WBC - white blood cell

Characteristics of excluded studies [ordered by study ID]

\begin{tabular}{ll}
\hline Study & Reason for exclusion \\
\hline Howell 2010 & No clinically relevant outcomes, only laboratory measures \\
\hline Jackson 1997 & $\begin{array}{l}\text { RCT of elderly people looking at the effect of cranberry juice on urinary acidity. } \\
\text { No relevant outcomes reported. }\end{array}$ \\
\hline Jass 2009 & No clinically relevant outcomes, laboratory measures of urine chemistry \\
\hline Lavigne 2008 & No clinically relevant outcomes, only laboratory measures of urine kinetics \\
\hline Schultz 1984 & $\begin{array}{l}\text { RCT, (placebo controlled) of eight subjects with multiple sclerosis. } \\
\text { Only randomised to } 20 \text { days of treatment. The inclusion criteria for this review was a minimum } \\
\text { length of treatment of one month. Furthermore, number of UTIs was not a primary outcome and } \\
\text { only descriptively reported. }\end{array}$ \\
\hline Tempera 2010 & \begin{tabular}{l} 
No clinically relevant outcomes, only laboratory measures of adhesion \\
\hline Valentova 2007
\end{tabular} \\
\hline Vidlar 2010 & \begin{tabular}{l} 
No clinically relevant outcomes, only laboratory measures of urine biochemistry \\
\hline
\end{tabular}
\end{tabular}

$\mathrm{RCT}$ - randomised controlled trial

Characteristics of studies awaiting assessment [ordered by study ID] 
Afshar 2012

Methods

\section{Participants}

Interventions

\section{Outcomes}

Notes

Bonetta 2011

\begin{tabular}{ll}
\hline Methods & Not clear \\
\hline Participants & Men with prostate cancer undergoing radiotherapy \\
\hline Interventions & Cranberry extract \\
\hline Outcomes & UTls \\
\hline Notes & Abstract only \\
\hline
\end{tabular}

\section{NCT01079169}

\section{Methods}

Participants

Interventions

Outcomes

Notes

\section{Stapleton 2012}

\begin{tabular}{ll}
\hline Methods & RCT \\
\hline Participants & Women who have had a UTI within the past year \\
\hline Interventions & Cranberry juice cocktail \\
\hline Outcomes & Rate of UTIs \\
\hline Notes & Study completed in 2009: no publications
\end{tabular}

Characteristics of ongoing studies [ordered by study ID] 
NCT00100061

\begin{tabular}{|c|c|}
\hline Trial name or title & Dose response to cranberry of women with recurrent UTIs \\
\hline Methods & $\mathrm{RCT}$ \\
\hline Participants & Women with recurrent UTIs \\
\hline Interventions & Cranberry juice \\
\hline Outcomes & UTIS \\
\hline Starting date & May 2007 \\
\hline Contact information & Principal investigator: Lynn Stothers Bladder Care Centre, University of British Columbia \\
\hline Notes & $\begin{array}{l}\text { Although due to finish in } 2011 \text {, the website states 'This study is ongoing, but not recruiting partici- } \\
\text { pants'. }\end{array}$ \\
\hline
\end{tabular}

\section{NCT00280592}

\begin{tabular}{ll}
\hline Trial name or title & $\begin{array}{l}\text { Prospective, randomized, double-blind, placebo-controlled study on parallel groups evaluating the } \\
\text { efficacy and safety of cranberry (Vaccinium macrocarpon) in prevention of urinary tract infections } \\
\text { in multiple sclerosis patients }\end{array}$ \\
\hline Methods & RCT \\
\hline Participants & Dry essence of cranberry presented as 18 mg of PAC sachets of powdered cranberry. Cranberry \\
\hline Interventions & juice is administered twice a day (in the morning and in the evening). \\
\hline Outcomes & Time to onset of a first UTI within one year of treatment \\
\hline Starting date & 2006 \\
\hline Contact information & Philippe Gallien, http://clinicaltrials.gov/ct2/show/NCT00280592 \\
\hline Notes & Study completed February 2008: no publications \\
\hline
\end{tabular}

\section{NCT01033383}

$\begin{array}{ll}\text { Trial name or title } & \begin{array}{l}\text { Pilot study: Dosing study of cranberry capsules for the prevention of bacteriuria in nursing home } \\ \text { residents }\end{array}\end{array}$

\begin{tabular}{ll}
\hline Methods & RCT \\
\hline Participants & Females at least 65 years of age or older who live in a nursing home and who have a history of UTIs \\
\hline Interventions & Different doses of cranberry capsules \\
\hline Outcomes & Time to onset of first UTI \\
\hline Starting date & 2009 \\
\hline
\end{tabular}


NCT01033383 (Continued)

Contact information http://clinicaltrials.gov/ct2/show/NCT01033383

Notes Should completed December 2010: no publications

PAC - proanthocyanidin; RCT - randomised controlled trial

DATA AND ANALYSES

Comparison 1. Cranberry products versus placebo/control

\begin{tabular}{|c|c|c|c|c|}
\hline Outcome or subgroup title & No. of studies & $\begin{array}{l}\text { No. of partici- } \\
\text { pants }\end{array}$ & Statistical method & Effect size \\
\hline $\begin{array}{l}1 \text { Participants with one or } \\
\text { more UTIs at follow-up }\end{array}$ & 13 & 2462 & Risk Ratio (M-H, Random, 95\% Cl) & $0.86[0.71,1.04]$ \\
\hline $\begin{array}{l}1.1 \text { Women with recurrent } \\
\text { UTIS }\end{array}$ & 4 & 594 & Risk Ratio (M-H, Random, 95\% Cl) & $0.74[0.42,1.31]$ \\
\hline 1.2 Elderly men and women & 2 & 413 & Risk Ratio (M-H, Random, 95\% Cl) & $0.75[0.39,1.44]$ \\
\hline $\begin{array}{l}\text { 1.3 People with neuropathic } \\
\text { bladder/spinal injuries }\end{array}$ & 2 & 353 & Risk Ratio (M-H, Random, 95\% Cl) & $0.95[0.75,1.20]$ \\
\hline 1.4 Pregnant women & 2 & 674 & Risk Ratio (M-H, Random, 95\% Cl) & $1.04[0.93,1.17]$ \\
\hline 1.5 Children & 2 & 309 & Risk Ratio (M-H, Random, 95\% Cl) & $0.48[0.19,1.22]$ \\
\hline 1.6 Radiotherapy patients & 1 & 119 & Risk Ratio (M-H, Random, 95\% Cl) & $1.15[0.75,1.77]$ \\
\hline 2 Adverse effects & 4 & & Risk Ratio (M-H, Random, 95\% Cl) & Subtotals only \\
\hline $\begin{array}{l}2.1 \text { Stomach burn and gener- } \\
\text { al weakness }\end{array}$ & 1 & 34 & Risk Ratio (M-H, Random, 95\% Cl) & $0.13[0.01,2.46]$ \\
\hline 2.2 Vomitting & 1 & 37 & Risk Ratio (M-H, Random, 95\% Cl) & $6.0[0.33,108.56]$ \\
\hline 2.3 Nausea & 2 & 187 & Risk Ratio (M-H, Random, 95\% Cl) & $0.96[0.23,3.94]$ \\
\hline 2.4 Diarrhoea & 1 & 37 & Risk Ratio (M-H, Random, 95\% Cl) & $0.85[0.06,12.59]$ \\
\hline 2.5 Gastroenteritis & 2 & 413 & Risk Ratio (M-H, Random, 95\% Cl) & $0.44[0.10,1.96]$ \\
\hline $\begin{array}{l}2.6 \text { Any gastrointestinal ef- } \\
\text { fect }\end{array}$ & 4 & 597 & Risk Ratio (M-H, Random, 95\% Cl) & $0.83[0.31,2.27]$ \\
\hline
\end{tabular}




\section{Analysis 1.1. Comparison 1 Cranberry products versus placebo/ control, Outcome 1 Participants with one or more UTIs at follow-up.}

$\begin{array}{ccccc}\text { Study or subgroup } & \begin{array}{c}\text { Cranber- } \\ \text { ry product } \\ \mathrm{n} / \mathrm{N}\end{array} & \begin{array}{c}\text { Place- } \\ \text { bo/control } \\ \mathrm{n} / \mathrm{N}\end{array} & \text { Risk Ratio } & \text { Weight } \\ & & & \mathrm{M}-\mathrm{H}, \text { Random, } 95 \% \mathrm{Cl} & \mathrm{M}-\mathrm{H}, \mathrm{Random}, 95 \% \mathrm{Cl}\end{array}$

\begin{tabular}{lrr} 
& $\mathbf{n} / \mathbf{N}$ & \\
\hline 1.1.1 Women with recurrent UTIs & & \\
Barbosa-Cesnik 2011 & $31 / 155$ & $23 / 164$ \\
Kontiokari 2001 & $12 / 46$ & $19 / 45$ \\
Sengupta 2011 & $2 / 21$ & $4 / 13$ \\
Stothers 2002 & $19 / 100$ & $16 / 50$ \\
Subtotal (95\% Cl) & $\mathbf{3 2 2}$ & $\mathbf{2 7 2}$
\end{tabular}

Total events: 64 (Cranberry product), 62 (Placebo/control) Heterogeneity: $\mathrm{Tau}^{2}=0.2 ; \mathrm{Chi}^{2}=8.5, \mathrm{df}=3(\mathrm{P}=0.04) ; \mathrm{I}^{2}=64.7 \%$

Test for overall effect: $Z=1.03(P=0.3)$

\subsubsection{Elderly men and women}

$\begin{array}{lrr}\text { McMurdo } 2005 & 7 / 187 & 14 / 189 \\ \text { PACS Study } 2008 & 13 / 20 & 12 / 17 \\ \text { Subtotal }(\mathbf{9 5} \% \mathbf{C l}) & \mathbf{2 0 7} & \mathbf{2 0 6}\end{array}$

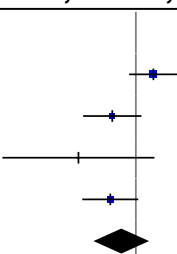

\section{$8.74 \%$}

$6.96 \%$

$1.46 \%$

$7.32 \%$

$\mathbf{2 4 . 4 8 \%}$
$1.43[0.87,2.33]$

$0.62[0.34,1.12]$

$0.31[0.07,1.46]$

$0.59[0.34,1.05]$

$0.74[0.42,1.31]$

Total events: 20 (Cranberry product), 26 (Placebo/control)

Heterogeneity: $\mathrm{Tau}^{2}=0.12 ; \mathrm{Chi}^{2}=1.92, \mathrm{df}=1(\mathrm{P}=0.17) ; \mathrm{I}^{2}=48.02 \%$

Test for overall effect: $\mathrm{Z}=0.87(\mathrm{P}=0.38)$

1.1.3 People with neuropathic bladder/spinal injuries

Lee 2007

$67 / 153$

Waites 2004

$10 / 26$

Subtotal $(95 \% \mathrm{CI})$

179

$71 / 152$

$8 / 22$

174

Total events: 77 (Cranberry product), 79 (Placebo/control)

Heterogeneity: Tau $^{2}=0 ; \mathrm{Chi}^{2}=0.09, \mathrm{df}=1(\mathrm{P}=0.76) ; \mathrm{I}^{2}=0 \%$

Test for overall effect: $Z=0.44(P=0.66)$

\subsubsection{Pregnant women}

Essadi 2010

Wing 2008

Subtotal $(95 \% \mathrm{Cl})$

$182 / 258$

$2 / 67$

325

Total events: 184 (Cranberry product), 194 (Placebo/control) Heterogeneity: $\mathrm{Tau}^{2}=0 ; \mathrm{Chi}^{2}=0.98, \mathrm{df}=1(\mathrm{P}=0.32) ; \mathrm{I}^{2}=0 \%$

Test for overall effect: $\mathrm{Z}=0.72(\mathrm{P}=0.47)$

\subsubsection{Children}

Ferrara 2009

Salo 2010

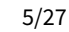

Subtotal $(95 \% \mathrm{Cl})$

$20 / 126$

153

Total events: 25 (Cranberry product), 46 (Placebo/control) Heterogeneity: $\mathrm{Tau}^{2}=0.34 ; \mathrm{Chi}^{2}=3.73, \mathrm{df}=1(\mathrm{P}=0.05) ; \mathrm{I}^{2}=73.17 \%$ Test for overall effect: $\mathrm{Z}=1.54(\mathrm{P}=0.12)$

\subsubsection{Radiotherapy patients}

Cowan 2012

Subtotal $(95 \% \mathrm{Cl})$

Total events: 26 (Cranberry product), 23 (Placebo/control)

Heterogeneity: Not applicable

Test for overall effect: $\mathrm{Z}=0.63(\mathrm{P}=0.53)$

$194 / 286$

349
272

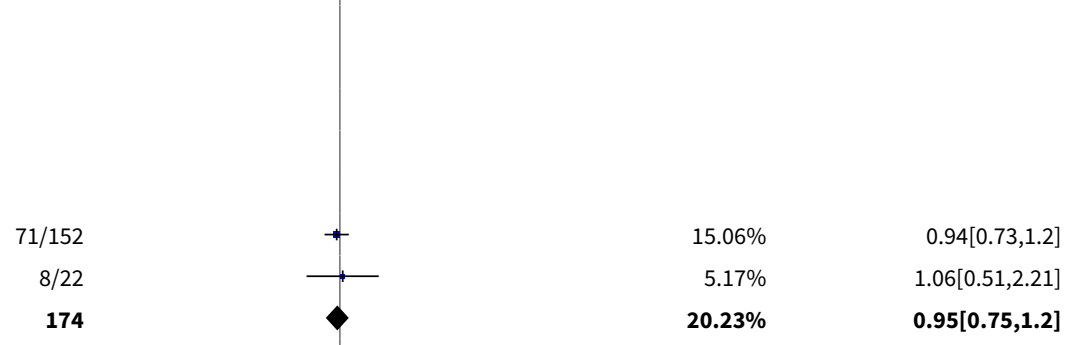




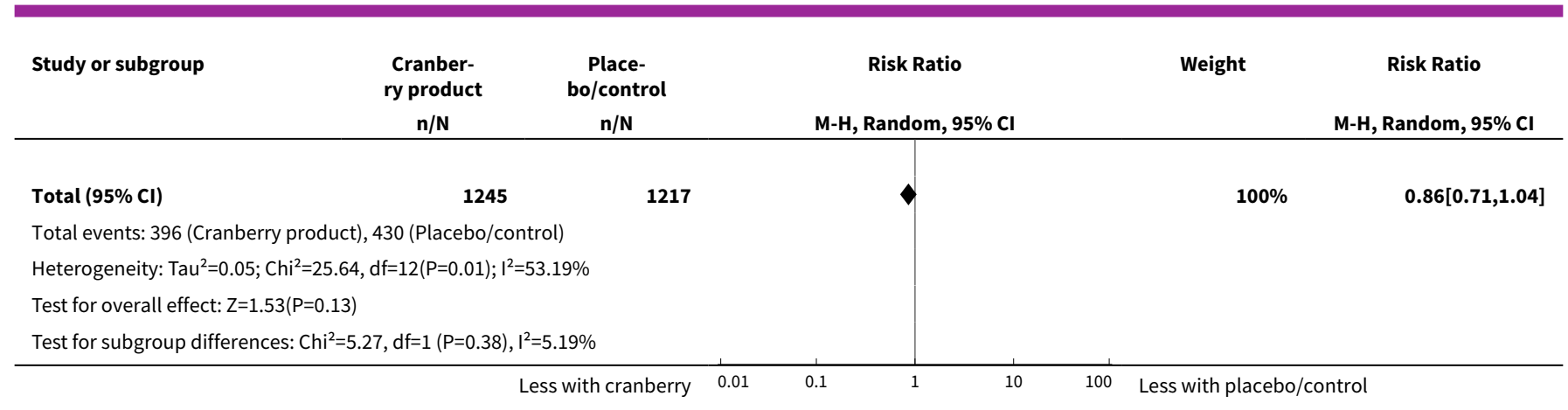

Analysis 1.2. Comparison 1 Cranberry products versus placebo/control, Outcome 2 Adverse effects.

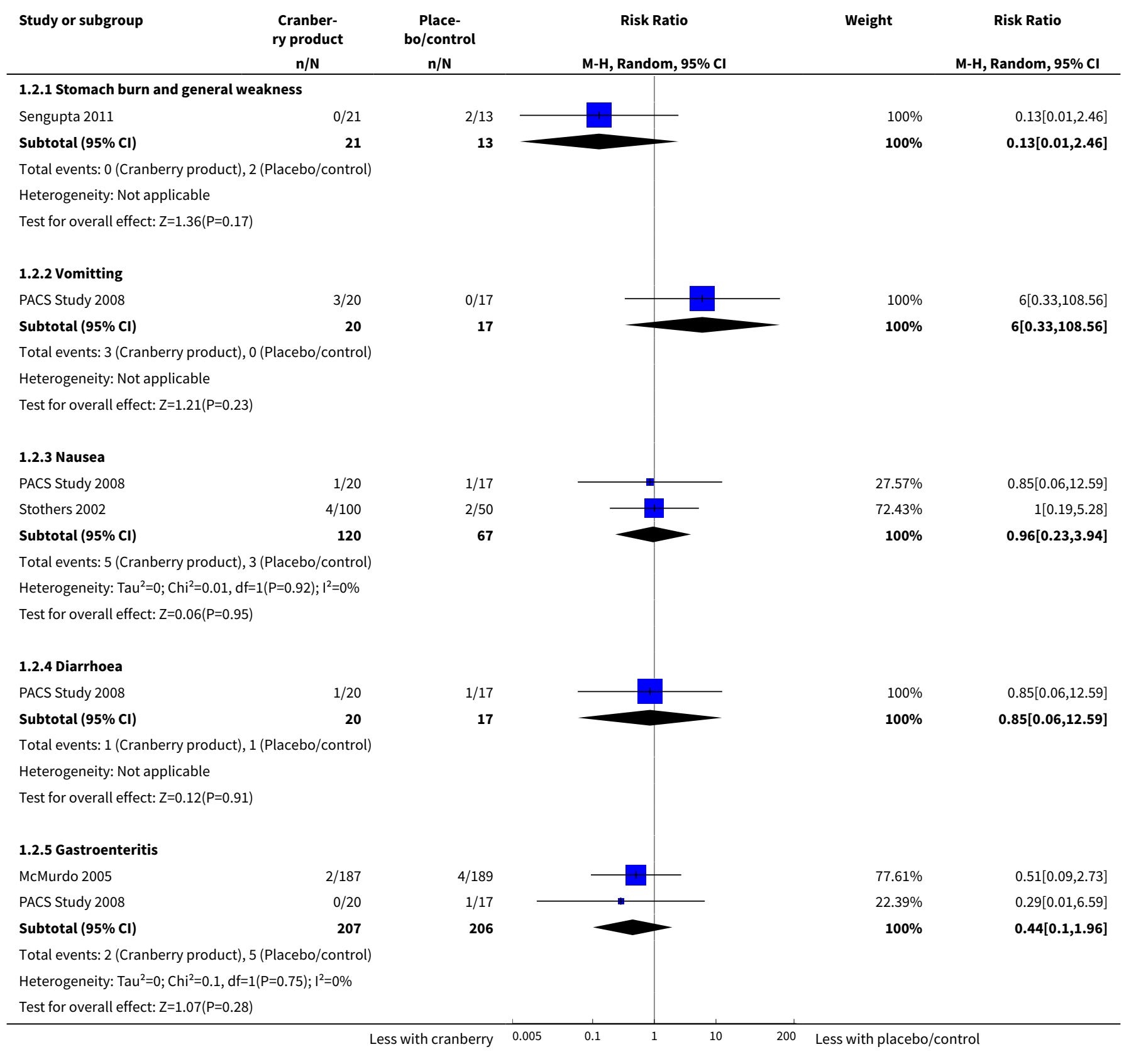




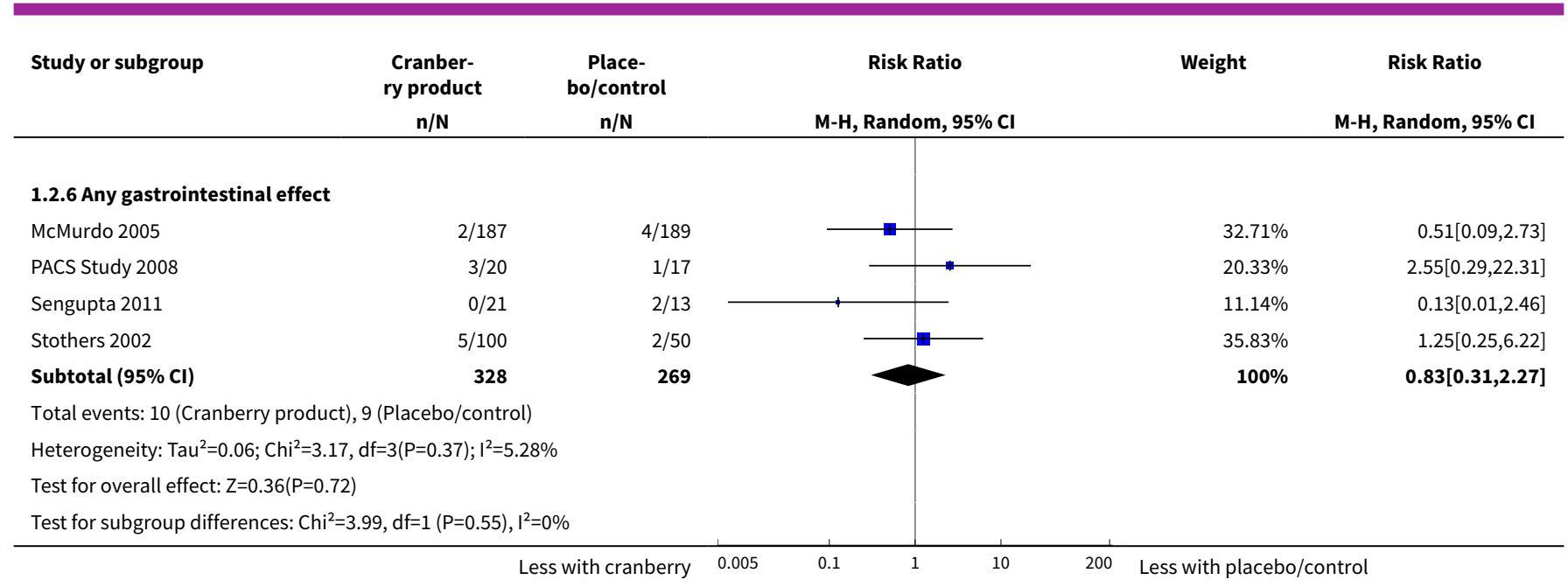

\section{Comparison 2. Cranberry products versus antibiotics}

\begin{tabular}{lllll}
\hline $\begin{array}{l}\text { Outcome or subgroup } \\
\text { title }\end{array}$ & No. of studies & $\begin{array}{l}\text { No. of partici- } \\
\text { pants }\end{array}$ & Statistical method & Effect size \\
\hline $\begin{array}{l}1 \text { Repeat symptomatic } \\
\text { UTI }\end{array}$ & 3 & 536 & Risk Ratio (M-H, Random, 95\% Cl) & $1.16[0.79,1.73]$ \\
\hline 1.1 Adult women & 2 & 344 & Risk Ratio (M-H, Random, 95\% Cl) & $1.31[0.85,2.02]$ \\
\hline 1.2 Children & 1 & 192 & Risk Ratio (M-H, Random, 95\% Cl) & $0.69[0.32,1.51]$ \\
\hline 2 Adverse effects & 2 & Risk Ratio (M-H, Random, 95\% Cl) & Subtotals only \\
\hline 2.1 Gastrointestinal & 2 & Risk Ratio (M-H, Random, 95\% Cl) & $0.78[0.42,1.42]$ \\
\hline 2.2 Rash or urticaria & 1 & Risk Ratio (M-H, Random, 95\% Cl) & $0.54[0.25,1.18]$ \\
\hline 2.3 Vaginal & 1 & 207 & Risk Ratio (M-H, Random, 95\% Cl) & $0.75[0.40,1.40]$ \\
\hline 2.4 Allergic reaction & 1 & 207 & Risk Ratio (M-H, Random, 95\% Cl) & $0.30[0.01,7.28]$ \\
\hline
\end{tabular}

Analysis 2.1. Comparison 2 Cranberry products versus antibiotics, Outcome 1 Repeat symptomatic UTI.

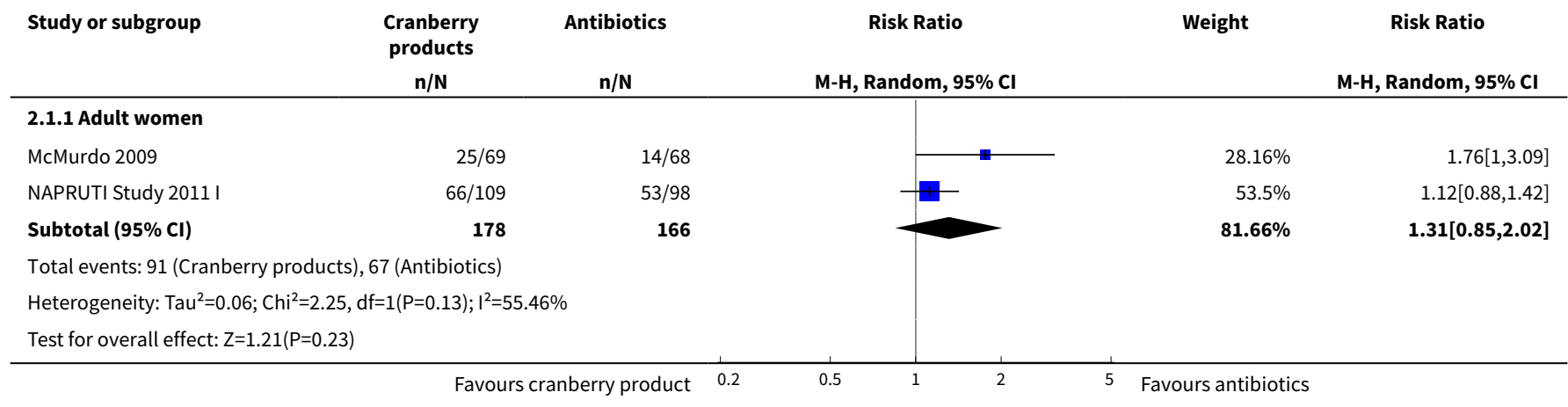




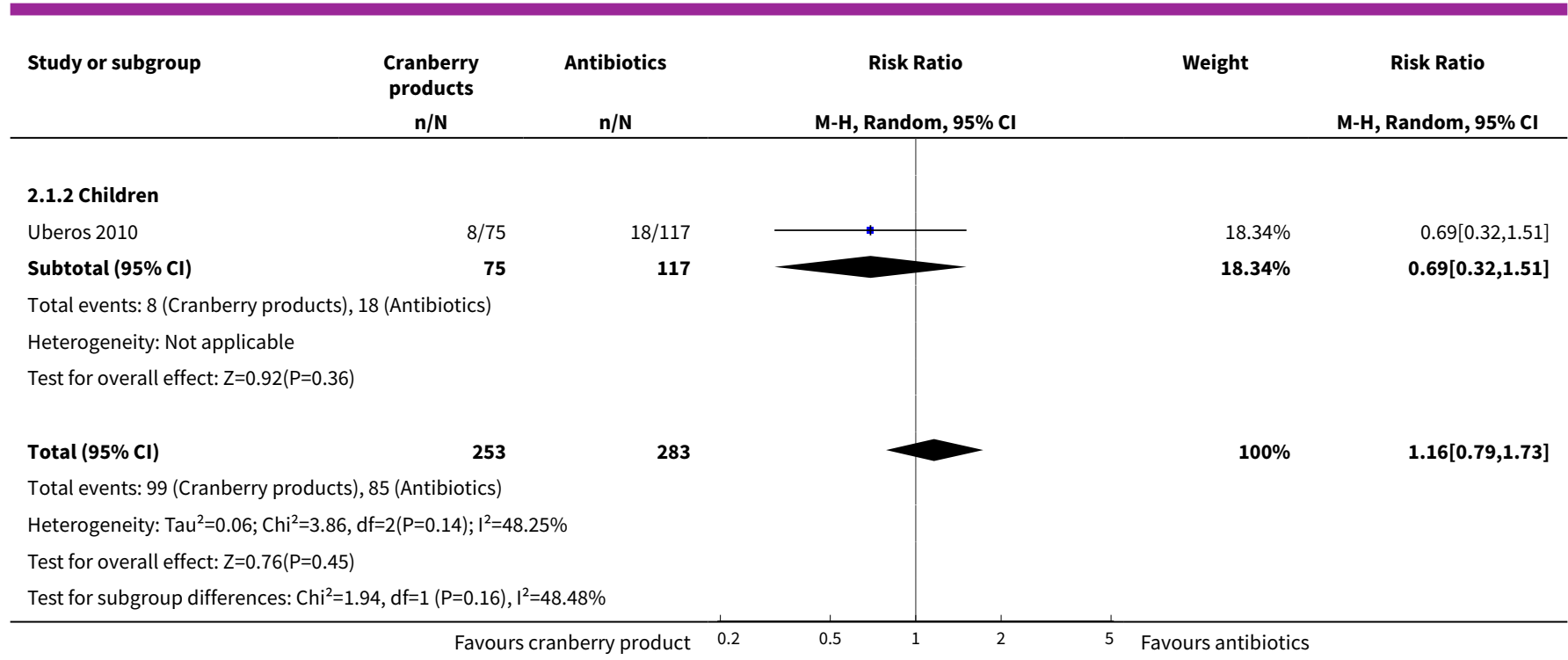

Analysis 2.2. Comparison 2 Cranberry products versus antibiotics, Outcome 2 Adverse effects.

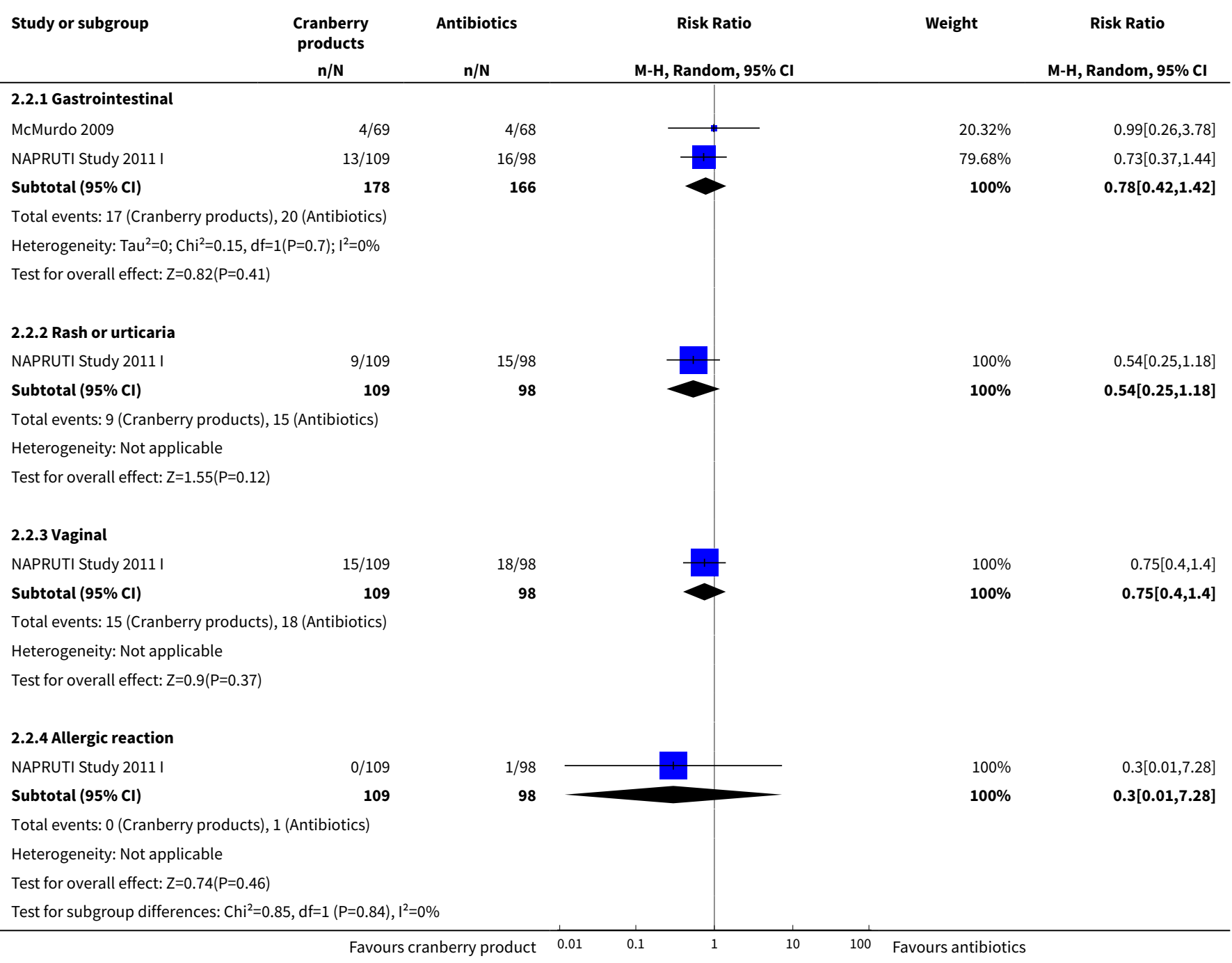


Comparison 3. Cranberry dose: 2 or more/day versus 1 dose/day

\begin{tabular}{|c|c|c|c|c|}
\hline $\begin{array}{l}\text { Outcome or subgroup ti- } \\
\text { tle }\end{array}$ & No. of studies & $\begin{array}{l}\text { No. of partici- } \\
\text { pants }\end{array}$ & Statistical method & Effect size \\
\hline 1 Symptomatic UTI & 3 & 208 & Risk Ratio (M-H, Random, 95\% Cl) & $1.12[0.75,1.68]$ \\
\hline 1.1 Pregnant women & 1 & 125 & Risk Ratio (M-H, Random, 95\% Cl) & $1.16[0.17,7.94]$ \\
\hline 1.2 Adult women & 1 & 44 & Risk Ratio (M-H, Random, 95\% Cl) & $0.91[0.14,5.92]$ \\
\hline $\begin{array}{l}1.3 \text { Elderly men and } \\
\text { women }\end{array}$ & 1 & 39 & Risk Ratio (M-H, Random, 95\% Cl) & $1.13[0.75,1.72]$ \\
\hline 2 Adverse effects & 1 & & Risk Ratio (M-H, Random, 95\% Cl) & Totals not selected \\
\hline $\begin{array}{l}2.1 \text { Weakness and abdomi- } \\
\text { nal pain }\end{array}$ & 1 & & Risk Ratio (M-H, Random, 95\% Cl) & $0.0[0.0,0.0]$ \\
\hline 2.2 Mild fever & 1 & & Risk Ratio (M-H, Random, 95\% Cl) & $0.0[0.0,0.0]$ \\
\hline 2.3 Heart burn & 1 & & Risk Ratio (M-H, Random, 95\% Cl) & $0.0[0.0,0.0]$ \\
\hline $\begin{array}{l}\text { 2.4 Stomach burn and gen- } \\
\text { eral weakness }\end{array}$ & 1 & & Risk Ratio (M-H, Random, 95\% Cl) & $0.0[0.0,0.0]$ \\
\hline
\end{tabular}

Analysis 3.1. Comparison 3 Cranberry dose: 2 or more/day versus 1 dose/day, Outcome 1 Symptomatic UTI.

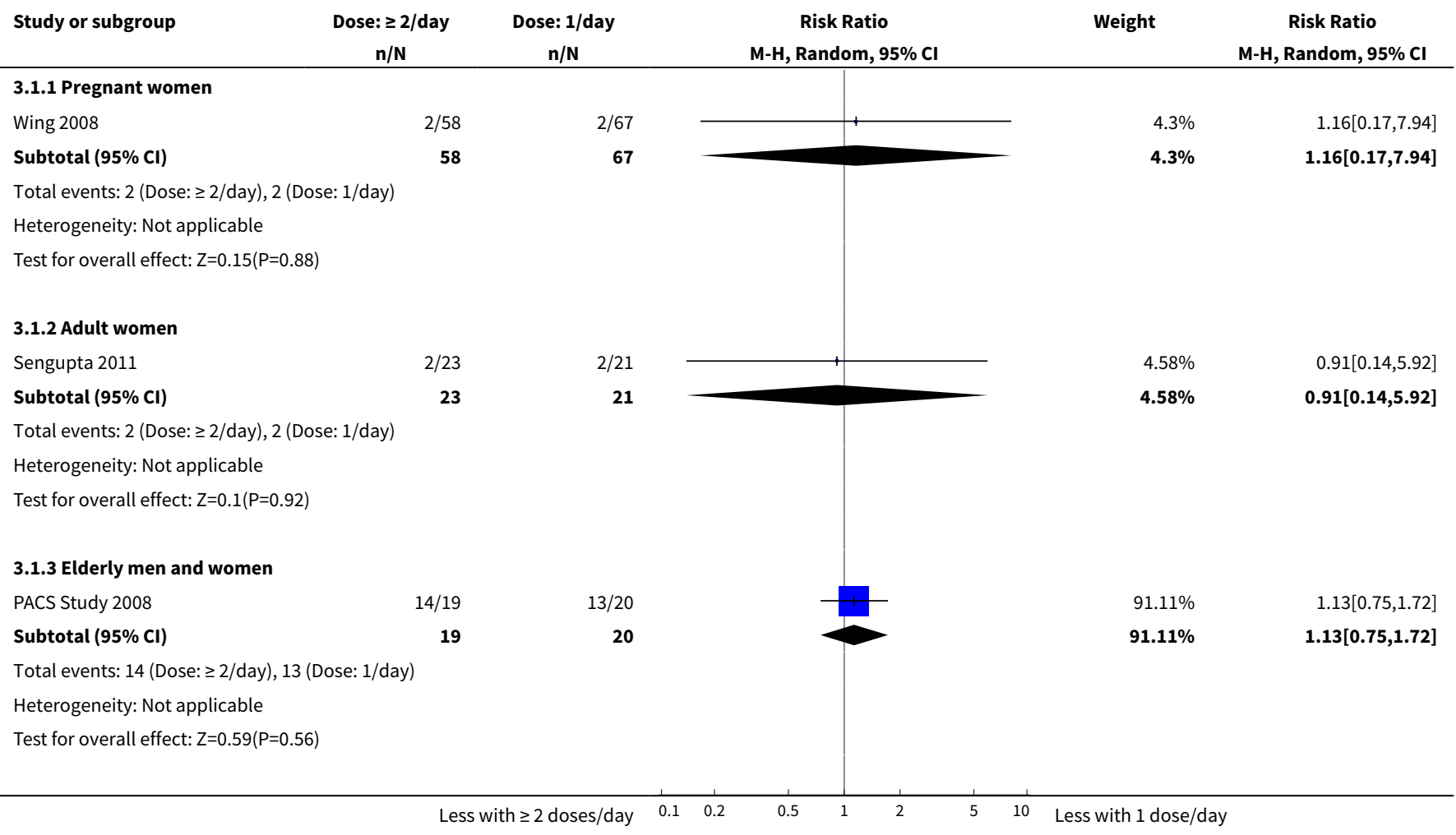




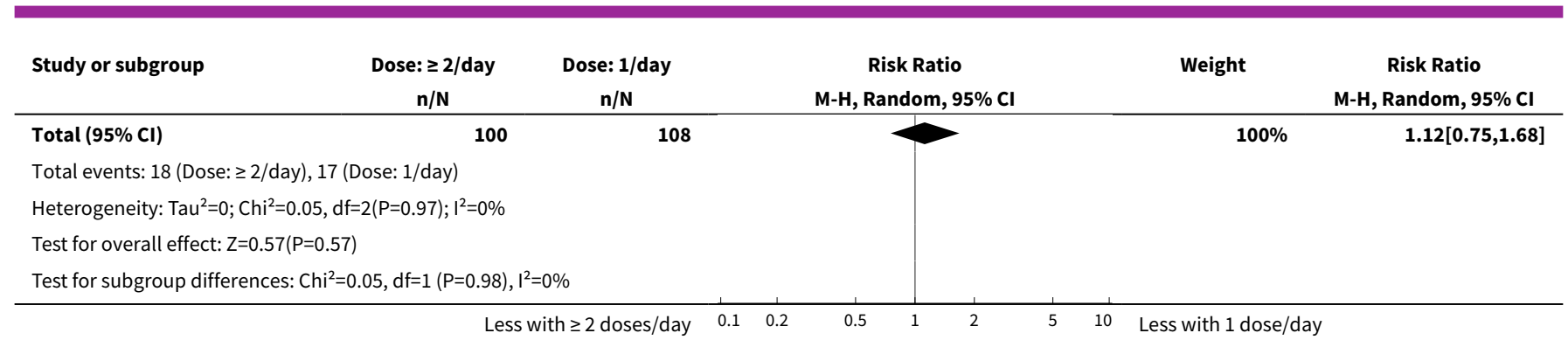

Analysis 3.2. Comparison 3 Cranberry dose: 2 or more/day versus 1 dose/day, Outcome 2 Adverse effects.

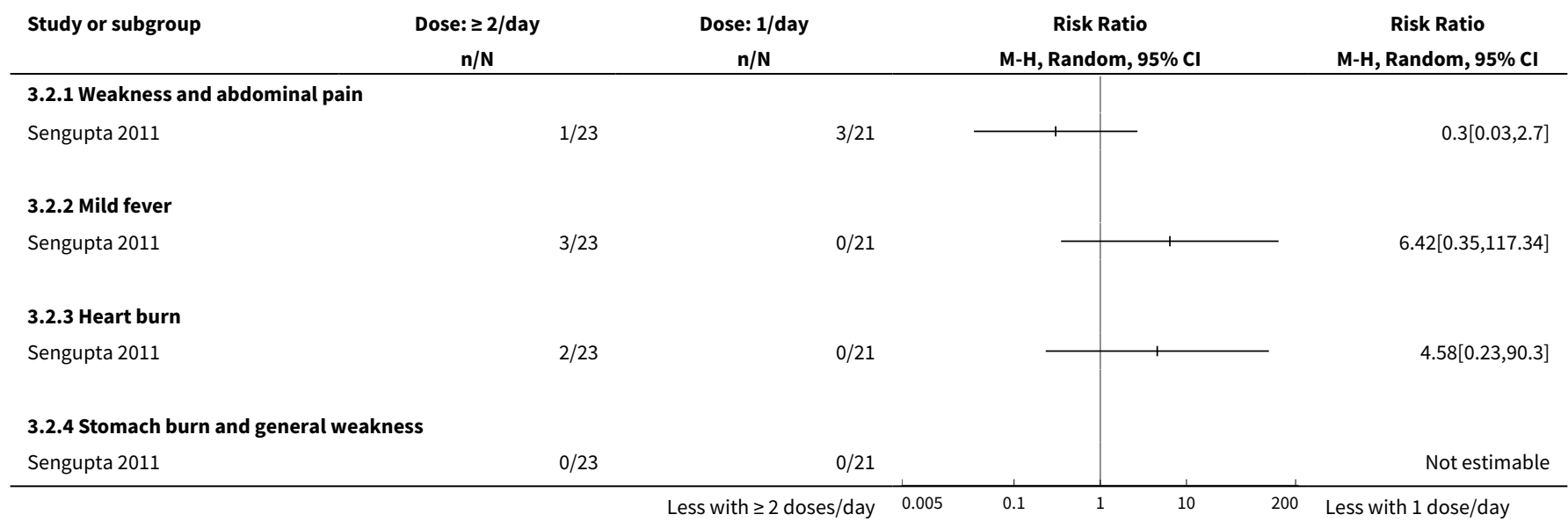

Comparison 4. Cranberry (dose: $\geq 2 /$ day) versus placebo

\begin{tabular}{|c|c|c|c|c|}
\hline $\begin{array}{l}\text { Outcome or subgroup } \\
\text { title }\end{array}$ & No. of studies & $\begin{array}{l}\text { No. of partici- } \\
\text { pants }\end{array}$ & Statistical method & Effect size \\
\hline 1 Symptomatic UTI & 3 & & Risk Ratio (M-H, Random, 95\% Cl) & Totals not selected \\
\hline 1.1 Pregnant women & 1 & & Risk Ratio (M-H, Random, 95\% Cl) & $0.0[0.0,0.0]$ \\
\hline $\begin{array}{l}1.2 \text { Elderly men and } \\
\text { women }\end{array}$ & 1 & & Risk Ratio (M-H, Random, 95\% Cl) & $0.0[0.0,0.0]$ \\
\hline 1.3 Adult women & 1 & & Risk Ratio (M-H, Random, 95\% Cl) & $0.0[0.0,0.0]$ \\
\hline 2 Adverse effects & 2 & & Risk Ratio (M-H, Random, 95\% Cl) & Totals not selected \\
\hline 2.1 Vomitting & 1 & & Risk Ratio (M-H, Random, 95\% Cl) & $0.0[0.0,0.0]$ \\
\hline 2.2 Nausea & 1 & & Risk Ratio (M-H, Random, 95\% Cl) & $0.0[0.0,0.0]$ \\
\hline 2.3 Diarrhoea & 1 & & Risk Ratio (M-H, Random, 95\% Cl) & $0.0[0.0,0.0]$ \\
\hline 2.4 Gastroenteritis & 1 & & Risk Ratio (M-H, Random, 95\% Cl) & $0.0[0.0,0.0]$ \\
\hline
\end{tabular}




\begin{tabular}{lllll}
\hline $\begin{array}{l}\text { Outcome or subgroup } \\
\text { title }\end{array}$ & No. of studies & $\begin{array}{l}\text { No. of partici- } \\
\text { pants }\end{array}$ & Statistical method & Effect size \\
\hline $\begin{array}{l}2.5 \text { Stomach burn and } \\
\text { general weakness }\end{array}$ & 1 & Risk Ratio (M-H, Random, 95\% Cl) & $0.0[0.0,0.0]$ \\
\hline
\end{tabular}

Analysis 4.1. Comparison 4 Cranberry (dose: $\geq 2$ /day) versus placebo, Outcome 1 Symptomatic UTI.

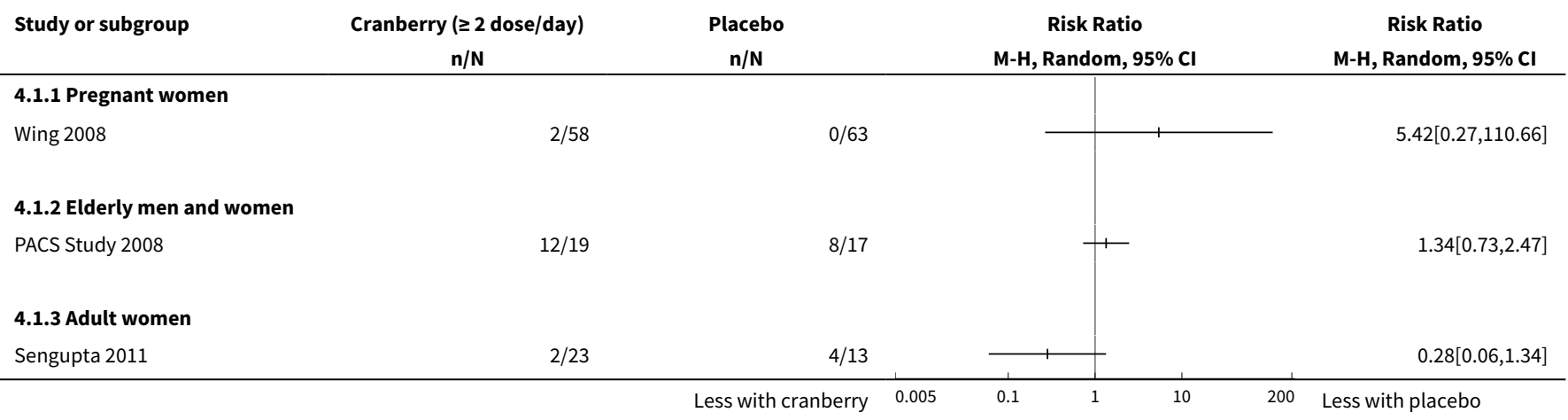

Analysis 4.2. Comparison 4 Cranberry (dose: $\geq 2$ /day) versus placebo, Outcome 2 Adverse effects.

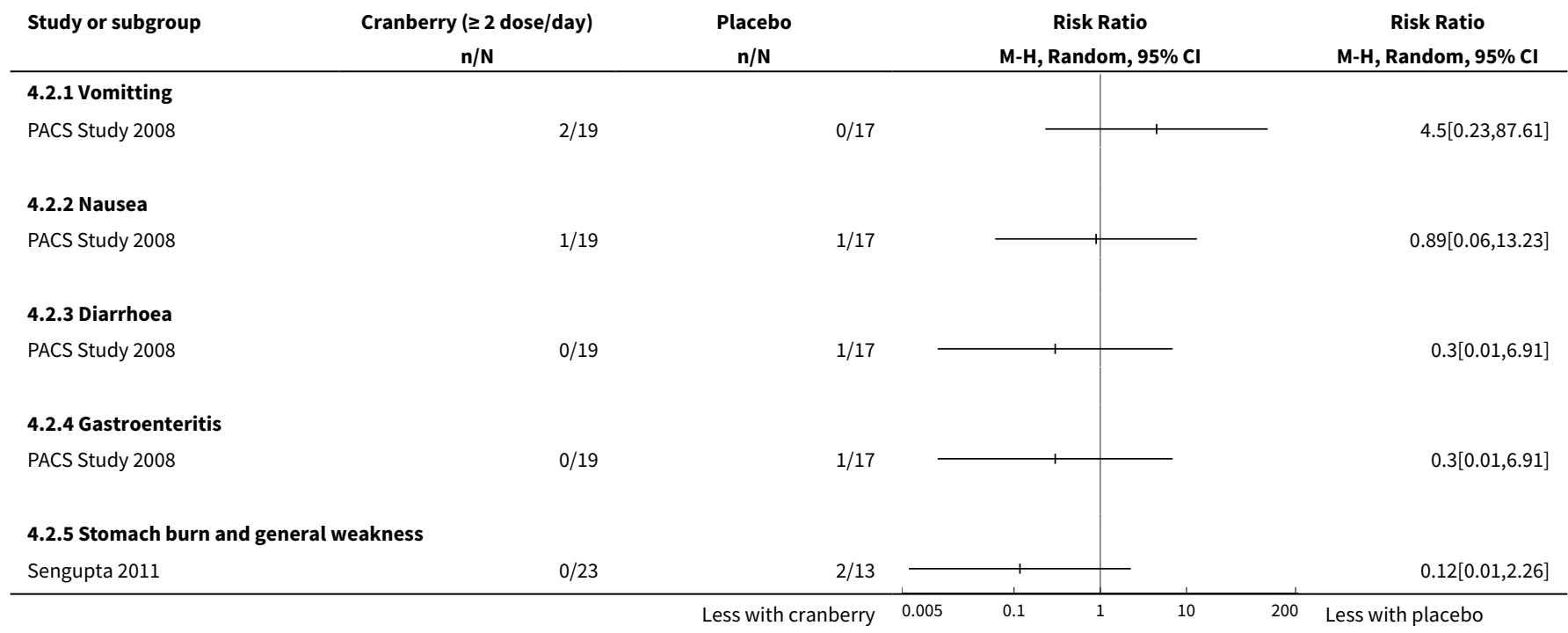

\section{Comparison 5. Cranberry products versus methenamine hippurate}

\begin{tabular}{lllll}
\hline Outcome or subgroup title & No. of studies & $\begin{array}{l}\text { No. of partici- } \\
\text { pants }\end{array}$ & Statistical method & Effect size \\
\hline 1 Symptomatic UTI & 1 & $\begin{array}{l}\text { Risk Ratio (M-H, Random, 95\% } \\
\text { Cl) }\end{array}$ & $\begin{array}{l}\text { Totals not select- } \\
\text { ed }\end{array}$ \\
\hline
\end{tabular}




\begin{tabular}{lllll}
\hline Outcome or subgroup title & No. of studies & $\begin{array}{l}\text { No. of partici- } \\
\text { pants }\end{array}$ & Statistical method & Effect size \\
\hline $\begin{array}{l}\text { 1.1 Spinal injured neuropathic blad- } \\
\text { der participants }\end{array}$ & 1 & $\begin{array}{l}\text { Risk Ratio (M-H, Random, 95\% } \\
\text { Cl) }\end{array}$ & $0.0[0.0,0.0]$ \\
\hline
\end{tabular}

\section{Analysis 5.1. Comparison 5 Cranberry products versus methenamine hippurate, Outcome 1 Symptomatic UTI.}

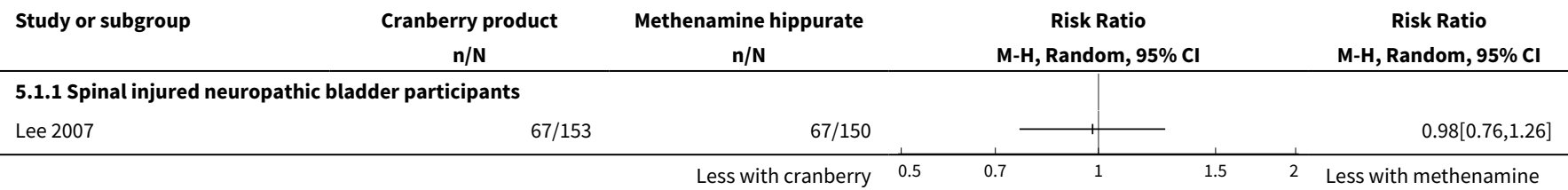

\section{Comparison 6. Cranberry versus probiotics}

\begin{tabular}{lllll}
\hline Outcome or subgroup title & No. of studies & $\begin{array}{l}\text { No. of partici- } \\
\text { pants }\end{array}$ & Statistical method & Effect size \\
\hline $\begin{array}{lllll}1 \text { Symptomatic UTI } \\
\text { 1.1 Children with previous }\end{array}$ & 1 & 152 & Risk Ratio (M-H, Random, 95\% Cl) & $0.42[0.24,0.74]$ \\
$\begin{array}{lllll}\text { UTI } \\
1.2 \text { Adult women }\end{array}$ & 1 & 53 & Risk Ratio (M-H, Random, 95\% Cl) & $0.44[0.18,1.09]$ \\
\hline
\end{tabular}

Analysis 6.1. Comparison 6 Cranberry versus probiotics, Outcome 1 Symptomatic UTI.

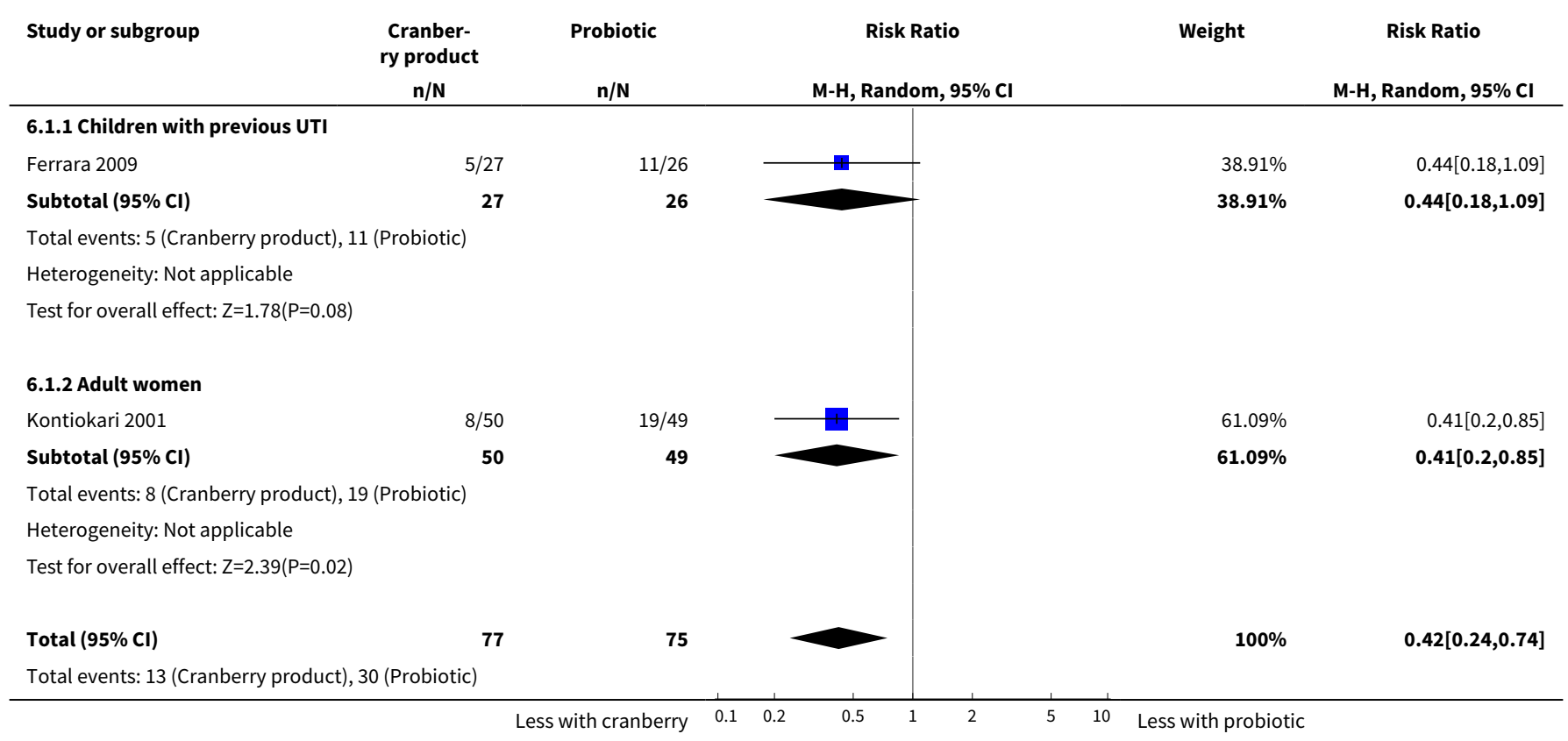




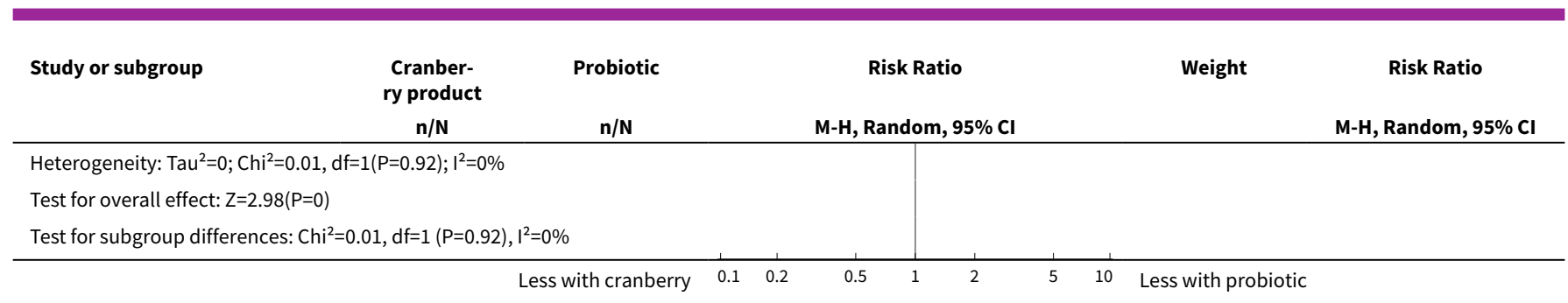

\section{ADDITIONAL TABLES}

Table 1. Characteristics of studies

\begin{tabular}{|c|c|c|c|c|c|c|}
\hline $\begin{array}{l}\text { Stduy } \\
\text { name }\end{array}$ & Year & $\mathbf{N}$ & Country & Setting & Participants & Intervention \\
\hline Avorn 1994 & 1994 & 192 & USA & $\begin{array}{l}\text { Nursing } \\
\text { homes }\end{array}$ & $\begin{array}{l}\text { Elderly women, } \\
\text { mean age } 78.5 \\
\text { years }\end{array}$ & $\begin{array}{l}\text { Cranberry juice cocktail: } 300 \mathrm{~mL} / \mathrm{d} \\
\text { (30\% cranberry concentrate) } \\
\text { Placebo beverage PAC content: NS }\end{array}$ \\
\hline $\begin{array}{l}\text { Haverkorn } \\
1994\end{array}$ & 1994 & 38 & $\begin{array}{l}\text { Nether- } \\
\text { lands }\end{array}$ & Hospital & $\begin{array}{l}\text { Elderly men (9) } \\
\text { and women (29), } \\
\text { mean age } 81 \\
\text { years }\end{array}$ & $\begin{array}{l}\text { Cranberry juice: } 15 \mathrm{~mL} \text {, twice a day } \\
\text { ( } 30 \mathrm{~mL} \text { cranberry juice/d, concentra- } \\
\text { tion not specified) } \\
\text { PAC content: NS }\end{array}$ \\
\hline Foda 1995 & 1995 & 40 & Canada & $\begin{array}{l}\text { Hospital } \\
\text { clinic }\end{array}$ & $\begin{array}{l}\text { Children with } \\
\text { neuropathic } \\
\text { bladder requir- } \\
\text { ing clean inter- } \\
\text { mittent catheter- } \\
\text { isation, mean } \\
\text { age } 9.35 \text { years }\end{array}$ & $\begin{array}{l}\text { Cranberry juice cocktail: } 15 \mathrm{~mL} / \mathrm{kg} / \\
\text { d ( } 30 \% \text { cranberry concentrate) } 3-4 \\
\text { times a day } \\
\text { PAC content: NS }\end{array}$ \\
\hline $\begin{array}{l}\text { Walker } \\
1997\end{array}$ & 1997 & 19 & USA & $\begin{array}{l}\text { Family } \\
\text { practice }\end{array}$ & $\begin{array}{l}\text { Young women } \\
\text { with recurrent } \\
\text { UTI, median age } \\
37 \text { years }\end{array}$ & $\begin{array}{l}\text { Cranberry capsules: } 400 \mathrm{mg} \text { of cran- } \\
\text { berry solids (total amount/d: NS) } \\
\text { PAC content: NS }\end{array}$ \\
\hline $\begin{array}{l}\text { Schlager } \\
1999\end{array}$ & 1999 & 15 & USA & $\begin{array}{l}\text { Hospital } \\
\text { clinic }\end{array}$ & $\begin{array}{l}\text { Children with } \\
\text { neuropathic } \\
\text { bladder requir- } \\
\text { ing clean inter- } \\
\text { mittent catheter- } \\
\text { isation, aged } \\
2-18 \text { years }\end{array}$ & $\begin{array}{l}\text { Cranberry juice cocktail: } 300 \mathrm{~mL} / \mathrm{d} \\
\text { (30\% cranberry concentrate) } \\
\text { PAC content: NS }\end{array}$ \\
\hline $\begin{array}{l}\text { Kontiokari } \\
2001\end{array}$ & 2001 & 150 & Finland & $\begin{array}{l}\text { Student } \\
\text { health ser- } \\
\text { vice }\end{array}$ & $\begin{array}{l}\text { Young women } \\
\text { (mean age } 29-32 \\
\text { years) with previ- } \\
\text { ous UTI }\end{array}$ & $\begin{array}{l}\text { Cranberry-lingonberry juice: } 50 \mathrm{~mL} \\
\text { once/d, } 5 \text { days/week ( } 7.5 \mathrm{~g} \text { cranberry } \\
\text { concentrate) } \\
\text { PAC content: NS }\end{array}$ \\
\hline $\begin{array}{l}\text { McGuiness } \\
2002\end{array}$ & 2002 & 135 & Canada & $\begin{array}{l}\text { Outpatient } \\
\text { clinic for } \\
\text { MS patients }\end{array}$ & $\begin{array}{l}\text { Patinets with } \\
\text { multiple sclero- } \\
\text { sis }\end{array}$ & $\begin{array}{l}\text { Cranberry tablet: } 8000 \mathrm{mg} \text {, once/d } \\
(\mathrm{am}) \text { for } 6 \text { months } \\
\text { PAC content: NS }\end{array}$ \\
\hline
\end{tabular}


Table 1. Characteristics of studies (Continued)

\begin{tabular}{|c|c|c|c|c|c|c|}
\hline $\begin{array}{l}\text { Stothers } \\
2002\end{array}$ & 2002 & 150 & Canada & Unclear & $\begin{array}{l}\text { Women with } \\
\text { recurrent UTI } \\
\text { (aged 21-72 } \\
\text { years) }\end{array}$ & $\begin{array}{l}\text { Cranberry juice: } 250 \mathrm{~mL} \text { three times/ } \\
\text { d or one concentrated cranberry } \\
\text { juice tablet twice daily (dose NS apart } \\
\text { from 'at least 1:30 parts concentrated } \\
\text { juice) } \\
\text { PAC content: NS (study authors did } \\
\text { not know if the product contained ac- } \\
\text { tive PAC or not) }\end{array}$ \\
\hline $\begin{array}{l}\text { Linsenmey- } \\
\text { er } 2004\end{array}$ & 2004 & 21 & USA & $\begin{array}{l}\text { Urology re- } \\
\text { habilitation } \\
\text { clinic }\end{array}$ & $\begin{array}{l}\text { Spinal cord in- } \\
\text { jury patients } \\
\text { with neuropathic } \\
\text { bladders }\end{array}$ & $\begin{array}{l}\text { Cranberry tablets: } 1200 \mathrm{mg} / \mathrm{d}(3 \times 400 \\
\text { mg tablets) } \\
\text { PAC content: NS }\end{array}$ \\
\hline $\begin{array}{l}\text { Waites } \\
2004\end{array}$ & 2004 & 48 & USA & $\begin{array}{l}\text { Hospital } \\
\text { clinic }\end{array}$ & $\begin{array}{l}\text { Spinal cord in- } \\
\text { jury patients } \\
\text { with neuropathic } \\
\text { bladders }\end{array}$ & $\begin{array}{l}\text { Cranberry juice capsule: } 2000 \text { mg/d } \\
\text { PAC content: NS }\end{array}$ \\
\hline $\begin{array}{l}\text { McMurdo } \\
2005\end{array}$ & 2005 & 376 & Scotland & Hospital & $\begin{array}{l}\text { Elderly inpa- } \\
\text { tients }\end{array}$ & $\begin{array}{l}\text { Cranberry juice: } 300 \mathrm{~mL} \text { once/d } \\
\text { PAC concentration: } 11.175 \mu \mathrm{g} / \mathrm{g} \text { (dry } \\
\text { solids basis) }\end{array}$ \\
\hline Lee 2007 & 2007 & 305 & Australia & Community & $\begin{array}{l}\text { Spinal cord in- } \\
\text { jury patients }\end{array}$ & $\begin{array}{l}\text { Cranberry tablets: } 1600 \mathrm{mg} / \mathrm{d} \\
\text { Methenamine hippurate tablet: } 2 \mathrm{mg} \\
\text { PAC content: NS }\end{array}$ \\
\hline Wing 2008 & 2008 & 115 & USA & $\begin{array}{l}\text { Pre-natal } \\
\text { clinic }\end{array}$ & Pregnant women & $\begin{array}{l}\text { Cranberry juice } \\
\text { - Group 2: } 240 \mathrm{~mL} \text { cranberry drink } \\
\text { at breakfast, placebo juice at other } \\
\text { meals } \\
\text { - Group 3: } 240 \mathrm{~mL} \text { cranberry juice } 3 \\
\text { times/d (dosage changed through- } \\
\text { out) } \\
\text { Mean PAC content: } 80 \mathrm{mg} / 240 \mathrm{~mL}\end{array}$ \\
\hline Hess 2008 & 2008 & 47 & USA & $\begin{array}{l}\text { Splnal cord } \\
\text { injury pa- } \\
\text { tients in } \\
\text { Veterans } \\
\text { Admin Hos- } \\
\text { pital }\end{array}$ & $\begin{array}{l}\text { Spinal cord in- } \\
\text { jury patients } \\
\text { with neurogenic } \\
\text { bladders }\end{array}$ & $\begin{array}{l}\text { Cranberry tablet: } 1000 \mathrm{mg} / \mathrm{d}(500 \mathrm{mg} \\
\text { tablet) } \\
\text { PAC concentration: NS }\end{array}$ \\
\hline $\begin{array}{l}\text { Ferrara } \\
2009\end{array}$ & 2009 & 80 & Italy & $\begin{array}{l}\text { Paediatric } \\
\text { nephrology } \\
\text { ambulatory } \\
\text { clinic }\end{array}$ & $\begin{array}{l}\text { Girls with }>1 \text { UTI } \\
\text { in past year }\end{array}$ & $\begin{array}{l}\text { Cranberry concentrate, } 50 \mathrm{~mL} \text { in } 50 \\
\mathrm{~mL} \text { water } \\
\text { Lactobacillus GG drink: } 100 \mathrm{~mL} \\
\text { PAC content: NS }\end{array}$ \\
\hline $\begin{array}{l}\text { McMurdo } \\
2009\end{array}$ & 2009 & 137 & UK & $\begin{array}{l}\text { Scottish } \\
\text { primary } \\
\text { care re- }\end{array}$ & $\begin{array}{l}\text { Women } \geq 45 \\
\text { years with } \geq 2 \\
\text { UTIs in the previ- } \\
\text { ous } 12 \text { months }\end{array}$ & $\begin{array}{l}\text { Cranberry tablet: } 500 \mathrm{mg} \\
\text { Antibiotic: } 100 \mathrm{mg} \text { TMP } \\
\text { PAC content: NS }\end{array}$ \\
\hline
\end{tabular}


Table 1. Characteristics of studies (Continued)

search net-

work

\begin{tabular}{|c|c|c|c|c|c|c|}
\hline Essadi 2010 & 2010 & 544 & Unsure & $\begin{array}{l}\text { Antenatal } \\
\text { clinic }\end{array}$ & Pregnant women & $\begin{array}{l}\text { Cranberry juice: } 250 \mathrm{~mL}, 4 \text { times/d } \\
\text { PAC content: NS }\end{array}$ \\
\hline $\begin{array}{l}\text { PACS Study } \\
2008\end{array}$ & 2010 & 56 & USA & $\begin{array}{l}\text { Nursing } \\
\text { home }\end{array}$ & $\begin{array}{l}\text { Elderly men and } \\
\text { women ( }>60 \\
\text { years) with de- } \\
\text { mentia }\end{array}$ & $\begin{array}{l}\text { Cranberry tablet: } 1 \text { x } 650 \text { mg or } 2 \text { x } \\
1300 \text { mg } \\
\text { PAC content: NS }\end{array}$ \\
\hline Salo 2010 & 2010 & 252 & Finland & Hospital & $\begin{array}{l}\text { Children with } \\
\text { UTI }\end{array}$ & $\begin{array}{l}\text { Cranberry juice: } 5 \mathrm{~mL} / \mathrm{kg} \text { up to } 300 \mathrm{~mL} \\
\text { PAC concentration: NS }\end{array}$ \\
\hline $\begin{array}{l}\text { Uberos } \\
2010\end{array}$ & 2010 & 51 & Spain & $\begin{array}{l}\text { Unclear, } \\
\text { possibly } \\
\text { hospital }\end{array}$ & $\begin{array}{l}\text { Children with } \\
\text { UTI }\end{array}$ & $\begin{array}{l}\text { Cranberry syrup: } 0.2 \mathrm{~mL} / \mathrm{kg} \\
\text { Antibiotic: } 8 \mathrm{mg} / \mathrm{kg} \text { TMP } \\
\text { 'The concentration guarantees that } \\
5 \mathrm{~mL} \text { of the syrup contains } 36 \mathrm{mg} \text { of } \\
\text { highly bioactive PAC extracted from } \\
\text { the cranberry syrup, measured by the } \\
\text { BL-DMAC method.' }\end{array}$ \\
\hline $\begin{array}{l}\text { Bar- } \\
\text { bosa-Ces- } \\
\text { nik } 2011\end{array}$ & 2011 & 319 & USA & $\begin{array}{l}\text { University } \\
\text { Health Ser- } \\
\text { vice }\end{array}$ & $\begin{array}{l}\text { Adult women } \\
\text { with urinary } \\
\text { symptoms }\end{array}$ & $\begin{array}{l}\text { Cranberry juice: } 2 \text { × } 240 \mathrm{~mL}(480 \mathrm{~mL} / \\
\text { d) } \\
\text { PAC concentration: } 112 \mathrm{mg} \text { (range 83- } \\
136 \mathrm{mg} \text {; SD } 614.1 \mathrm{mg} \text { ) }\end{array}$ \\
\hline $\begin{array}{l}\text { NAPRUTI } \\
\text { Study } 2011 \\
\text { I }\end{array}$ & 2011 & 199 & $\begin{array}{l}\text { Nether- } \\
\text { lands }\end{array}$ & $\begin{array}{l}\text { Primary } \\
\text { care physi- } \\
\text { cians }\end{array}$ & $\begin{array}{l}\text { Adult women } \\
\text { (premenopausal) } \\
\text { with at least } 3 \\
\text { UTIs in previous } \\
12 \text { months }\end{array}$ & $\begin{array}{l}\text { Cranberry tablet: } 2 \text { x } 500 \text { mg/d } \\
\text { Antibiotic: } 480 \text { mg TMP-SMX } \\
\text { Type A PAC in cranberry extract: } 9.1 \\
\text { mg/g }\end{array}$ \\
\hline $\begin{array}{l}\text { Sengupta } \\
2011\end{array}$ & 2011 & 57 & India & $\begin{array}{l}\text { Medical } \\
\text { clinic }\end{array}$ & Adult women & $\begin{array}{l}\text { Cranberry tablets: } 500 \mathrm{mg} / \mathrm{d} \text { or } 1000 \\
\mathrm{mg} / \mathrm{d} \\
\text { PAC content: } 1.5 \%\end{array}$ \\
\hline $\begin{array}{l}\text { Cowan } \\
2012\end{array}$ & 2012 & 128 & UK & $\begin{array}{l}\text { Oncology } \\
\text { unit }\end{array}$ & $\begin{array}{l}\text { Adults with blad- } \\
\text { der or cervical } \\
\text { cancer }\end{array}$ & $\begin{array}{l}\text { Cranberry juice: twice daily, volume } \\
\text { (NS), PAC concentration (NS) }\end{array}$ \\
\hline
\end{tabular}

DMAC - dimethylaminocinnamaldehyde; NS - not stated; PAC - proanthocyanidin; SD - standard deviation; SMX - sulfamethoxazole; TMP - trimethoprim 


\begin{tabular}{|c|c|c|c|c|c|c|c|c|c|}
\hline $\begin{array}{l}\text { Study } \\
\text { name }\end{array}$ & Design & $\begin{array}{l}\text { Study du- } \\
\text { ration }\end{array}$ & $\begin{array}{l}\text { Urine col- } \\
\text { lection }\end{array}$ & Threshold & $\begin{array}{l}\text { Other defini- } \\
\text { tions }\end{array}$ & Allocation & $\begin{array}{l}\text { Loss to } \\
\text { follow-up }\end{array}$ & Blinding & $\begin{array}{l}\text { Inten- } \\
\text { tion-to- } \\
\text { treat }\end{array}$ \\
\hline $\begin{array}{l}\text { Avorn } \\
1994\end{array}$ & Parallel & 6 months & Voided & $\geq 10^{8} / \mathrm{L}$ & $\begin{array}{l}\text { Pyuria (not de- } \\
\text { fined) }\end{array}$ & $\begin{array}{l}\text { No (qua- } \\
\text { si-RCT by } \\
\text { ID or phone } \\
\text { number) }\end{array}$ & $\begin{array}{l}39 / 192 \\
(20 \%)\end{array}$ & $\begin{array}{l}\text { Participants: yes } \\
\text { Investigators: yes }\end{array}$ & No \\
\hline $\begin{array}{l}\text { Haverkorn } \\
1994\end{array}$ & Cross-over & 4 weeks & NS & $=10^{8} / \mathrm{L}$ & NS & $\begin{array}{l}\text { No (qua- } \\
\text { si-RCT by } \\
\text { date of } \\
\text { birth) }\end{array}$ & $\begin{array}{l}21 / 38 \\
(55 \%)\end{array}$ & Unclear & Unclear \\
\hline Foda 1995 & Cross-over & $\begin{array}{l}12 \text { months } \\
\text { ( } 6 \text { months } \\
\text { of each } \\
\text { treatment) }\end{array}$ & CSU & $\begin{array}{l}\geq 108 / L(1 \\
\text { or } 2 \text { organ- } \\
\text { isms) }\end{array}$ & $\begin{array}{l}\text { Symptoms (not } \\
\text { defined) }\end{array}$ & Unclear & $\begin{array}{l}19 / 40 \\
(47.5 \%)\end{array}$ & Investigators: yes & Unclear \\
\hline $\begin{array}{l}\text { Walker } \\
1997\end{array}$ & Cross-over & 3 months & NS & NS & $\begin{array}{l}\text { Symptoms } \\
\text { present (not de- } \\
\text { fined) }\end{array}$ & Unclear & $\begin{array}{l}9 / 19 \\
(47.4 \%)\end{array}$ & $\begin{array}{l}\text { Participants: yes } \\
\text { Investigators: yes }\end{array}$ & Unclear \\
\hline $\begin{array}{l}\text { Schlager } \\
1999\end{array}$ & Cross-over & 3 months & CSU & $=10^{7} / \mathrm{L}$ & $\begin{array}{l}\text { Symptoms } \\
\text { present (defined) }\end{array}$ & $\begin{array}{l}\text { Yes, phar- } \\
\text { macy }\end{array}$ & $0 / 15(0 \%)$ & $\begin{array}{l}\text { Participants: yes } \\
\text { Investigators: yes }\end{array}$ & Yes \\
\hline $\begin{array}{l}\text { Kontiokari } \\
2001\end{array}$ & $\begin{array}{l}\text { Parallel, } 3 \\
\text { groups }\end{array}$ & 6 months & Voided & $=10^{8} / \mathrm{L}$ & $\begin{array}{l}\text { Symptoms } \\
\text { present (defined) }\end{array}$ & $\begin{array}{l}\text { Yes, sealed } \\
\text { opaque en- } \\
\text { velopes }\end{array}$ & $\begin{array}{l}13 / 150 \\
(8.7 \%)\end{array}$ & Unclear & Yes \\
\hline $\begin{array}{l}\text { McGuiness } \\
2002\end{array}$ & Parallel & 6 months & $\begin{array}{l}\text { Inter- } \\
\text { mittent } \\
\text { catheteri- } \\
\text { sation or } \\
\text { voided }\end{array}$ & $\geq 10^{9} / \mathrm{L}$ & $\begin{array}{l}\text { Leucocytes, } \\
\text { blood or nitrite } \\
\text { plus culture pos- } \\
\text { itive (symptoms } \\
\text { may be unrecog- } \\
\text { nised in these pa- } \\
\text { tients) }\end{array}$ & Unclear & $\begin{array}{l}3 \text { lost to } \\
\text { follow-up, } \\
9 \text { with- } \\
\text { drew }\end{array}$ & States double blinded, unsure who & Yes \\
\hline $\begin{array}{l}\text { Stothers } \\
2002\end{array}$ & $\begin{array}{l}\text { Parallel, } 3 \\
\text { group fac- } \\
\text { torial de- } \\
\text { sign }\end{array}$ & 12 months & Voided & $=10^{8} / \mathrm{L}$ & $\begin{array}{l}\text { Symptoms } \\
\text { present (unde- } \\
\text { fined) }\end{array}$ & $\begin{array}{l}\text { Yes, sealed } \\
\text { envelopes }\end{array}$ & $\begin{array}{l}2 / 150 \\
(1.3 \%)\end{array}$ & $\begin{array}{l}\text { Participants: yes } \\
\text { Investigators: yes }\end{array}$ & Yes \\
\hline
\end{tabular}




\begin{tabular}{|c|c|c|c|c|c|c|c|c|c|}
\hline $\begin{array}{l}\text { Linsen- } \\
\text { meyer } \\
2004\end{array}$ & Cross-over & 9 weeks & $\begin{array}{l}\text { CSU or } \\
\text { voided }\end{array}$ & $=10^{8} / \mathrm{L}$ & WBC count & Unclear & $16 / 37$ & $\begin{array}{l}\text { Participants: yes } \\
\text { Investigators: yes }\end{array}$ & \\
\hline $\begin{array}{l}\text { Waites } \\
2004\end{array}$ & Parallel & 6 months & $\begin{array}{l}\text { CSU or } \\
\text { voided }\end{array}$ & $=10^{7} / \mathrm{L}$ & $\begin{array}{l}\text { Symptoms (de- } \\
\text { fined) }\end{array}$ & Unclear & $26 / 74$ & $\begin{array}{l}\text { Participants: yes } \\
\text { Investigators: yes }\end{array}$ & No \\
\hline $\begin{array}{l}\text { McMurdo } \\
2005\end{array}$ & Parallel & 6 months & Voided & $=10^{4} / \mathrm{L}$ & $\begin{array}{l}\text { Symptoms } \\
\text { present (not de- } \\
\text { fined) }\end{array}$ & $\begin{array}{l}\text { Yes, sealed } \\
\text { envelopes }\end{array}$ & $0 / 376$ & $\begin{array}{l}\text { Participants: yes } \\
\text { Investigators: yes }\end{array}$ & Yes \\
\hline Lee 2007 & $\begin{array}{l}\text { Parallel, } 4 \\
\text { group fac- } \\
\text { torial de- } \\
\text { sign }\end{array}$ & 6 months & $\begin{array}{l}\text { CSU or re- } \\
\text { flex voided }\end{array}$ & $\geq 10^{8} / \mathrm{L}$ & $\begin{array}{l}\text { Symptoms } \\
\text { present (defined) }\end{array}$ & $\begin{array}{l}\text { External and } \\
\text { robust }\end{array}$ & $0 / 305$ & $\begin{array}{l}\text { Participants: yes } \\
\text { Investigators: yes } \\
\text { Outcome assessors: yes }\end{array}$ & Yes \\
\hline Wing 2008 & $\begin{array}{l}\text { Parallel, } 3 \\
\text { groups }\end{array}$ & $\begin{array}{l}5-7 \\
\text { months } \\
\text { (to deliv- } \\
\text { ery) }\end{array}$ & Voided & $\geq 10^{8} / \mathrm{L}$ & $\begin{array}{l}\text { Symptoms (de- } \\
\text { fined) }\end{array}$ & Unclear & $0 / 115$ & $\begin{array}{l}\text { Participants: yes } \\
\text { Investigators: yes } \\
\text { Outcome assessors: yes }\end{array}$ & Yes \\
\hline Hess 2008 & Cross-over & 6 months & $\begin{array}{l}\text { Assume } \\
\text { voided }\end{array}$ & $\geq 10^{7} \mathrm{cfu} / \mathrm{L}$ & $\begin{array}{l}\text { Symptoms (de- } \\
\text { fined) }\end{array}$ & Yes, stated & $10 / 57$ & $\begin{array}{l}\text { Participants: yes } \\
\text { Clinicians: yes }\end{array}$ & No \\
\hline $\begin{array}{l}\text { Ferrara } \\
2009\end{array}$ & $\begin{array}{l}\text { Parallel, } 3 \\
\text { groups }\end{array}$ & 6 months & Voided & $\geq 10^{8} / \mathrm{L}$ & $\begin{array}{l}\text { Symptoms (de- } \\
\text { fined) }\end{array}$ & Unclear & $4 / 84(5 \%)$ & $\begin{array}{l}\text { Participants: no } \\
\text { Investigators: unclear } \\
\text { Outcome assessors: unclear }\end{array}$ & Unclear \\
\hline $\begin{array}{l}\text { McMurdo } \\
2009\end{array}$ & Parallel & 6 months & Voided & $\geq 10^{7} / \mathrm{L}$ & $\begin{array}{l}\text { Symptoms (de- } \\
\text { fined) }\end{array}$ & $\begin{array}{l}\text { Externally } \\
\text { managed, } \\
\text { trial number } \\
\text { given }\end{array}$ & $0 / 137$ & $\begin{array}{l}\text { Participants: yes Investigators: yes } \\
\text { Outcome assessors: yes }\end{array}$ & Yes \\
\hline $\begin{array}{l}\text { Essadi } \\
2010\end{array}$ & Parallel & NS & $\begin{array}{l}\text { Assume } \\
\text { voided }\end{array}$ & NS & NS & NS & $216 / 760$ & $\begin{array}{l}\text { Participants: no } \\
\text { Investigators: NS }\end{array}$ & Unclear \\
\hline $\begin{array}{l}\text { PACS } \\
\text { Study } \\
2008\end{array}$ & $\begin{array}{l}\text { Parallel, } 3 \\
\text { groups }\end{array}$ & 6 months & $\begin{array}{l}\text { Assume } \\
\text { voided }\end{array}$ & $\geq 10^{8} / \mathrm{L}$ & NS & NS & $2 / 56$ & Stated no blinding & No \\
\hline
\end{tabular}




\begin{tabular}{|c|c|c|c|c|c|c|c|c|c|}
\hline Salo 2010 & Parallel & 6 months & NS & NS & NS & NS & $11 / 263$ & $\begin{array}{l}\text { Participants: yes } \\
\text { Investigators: yes }\end{array}$ & Unclear \\
\hline $\begin{array}{l}\text { Uberos } \\
2010\end{array}$ & Parallel & $\begin{array}{l}\text { when a } \\
\text { UTI was } \\
\text { recorded }\end{array}$ & $\begin{array}{l}\text { Voided, } \\
\text { MSU }\end{array}$ & $=10^{4} / \mathrm{L}$ & Symptoms & $\begin{array}{l}\text { Yes, hospital } \\
\text { pharmacy }\end{array}$ & $6 / 198$ & $\begin{array}{l}\text { Participants: yes } \\
\text { Clinicians: yes }\end{array}$ & Yes \\
\hline $\begin{array}{l}\text { Bar- } \\
\text { bosa-Ces- } \\
\text { nik } 2011\end{array}$ & Parallel & 6 months & $\begin{array}{l}\text { Voided, } \\
\text { MSU }\end{array}$ & $\geq 10^{6} \mathrm{cfu} / \mathrm{L}$ & $\begin{array}{l}\text { Symptoms (de- } \\
\text { fined) }\end{array}$ & Yes, external & $100 / 419$ & $\begin{array}{l}\text { Participants: yes } \\
\text { Investigators: yes Outcome asses- } \\
\text { sors: yes }\end{array}$ & Yes \\
\hline $\begin{array}{l}\text { NAPRUTI } \\
\text { Study } \\
20111\end{array}$ & Parallel & 12 months & Voided & $\geq 10^{6} \mathrm{cfu} / \mathrm{L}$ & $\begin{array}{l}\text { Symptoms (not } \\
\text { defined) }\end{array}$ & Yes & $22 / 221$ & $\begin{array}{l}\text { Participants: yes } \\
\text { Investigators: yes } \\
\text { Outcome assessors: yes }\end{array}$ & Unclear \\
\hline $\begin{array}{l}\text { Sengupta } \\
2011\end{array}$ & $\begin{array}{l}\text { Parallel, } 3 \\
\text { groups }\end{array}$ & 90 days & $\begin{array}{l}\text { Voided, } \\
\text { MSU }\end{array}$ & $\geq 10^{7} \mathrm{cfu} / \mathrm{L}$ & $\begin{array}{l}\text { Symptoms (not } \\
\text { defined) }\end{array}$ & $\begin{array}{l}\text { Yes, sealed } \\
\text { pre pre- } \\
\text { pared en- } \\
\text { velopes }\end{array}$ & $3 / 60$ & $\begin{array}{l}\text { High and low dose participants: yes } \\
\text { 'no treatment' participants: no } \\
\text { Investigators: no }\end{array}$ & Unclear \\
\hline $\begin{array}{l}\text { Cowan } \\
2012\end{array}$ & Parallel & 6 weeks & Voided & $\geq 10^{8} / \mathrm{L}$ & $\begin{array}{l}\text { Symptoms (not } \\
\text { defined) }\end{array}$ & Unclear & $15 / 128$ & $\begin{array}{l}\text { Participants: yes } \\
\text { Clinicians: yes } \\
\text { Outcome assessors: unclear }\end{array}$ & Yes \\
\hline
\end{tabular}

CSU - catheter specimen of urine; NS - not stated; WBC - white blood cell 
Table 3. Positive urine culture (bacteriuria)

\begin{tabular}{|c|c|c|c|c|c|}
\hline Study name & $\begin{array}{l}\text { Pre cross- } \\
\text { over }\end{array}$ & P value & End of study data & $P$ value & Notes \\
\hline \multirow[t]{2}{*}{ Schlager 1999} & $\begin{array}{l}\text { Cranberries: } \\
85 / 97\end{array}$ & NS & $\begin{array}{l}\text { Cranberries: } 120 / 160 \\
(75 \%)\end{array}$ & NS & \\
\hline & $\begin{array}{l}\text { Placebo: } \\
33 / 55\end{array}$ & & Placebo $114 / 151$ (75\%) & & \\
\hline $\begin{array}{l}\text { Haverkorn } \\
1994\end{array}$ & NS & NS & NS & $P=0.004$ & $\begin{array}{l}\text { Actual number of people in each } \\
\text { group: NS }\end{array}$ \\
\hline \multirow[t]{2}{*}{ Avorn 1994} & $\mathrm{~N} / \mathrm{A}$ & $\mathrm{N} / \mathrm{A}$ & $\begin{array}{l}\text { Cranberries: } 20 / 473(4 \%) \\
\text { of the urine samples }\end{array}$ & $\begin{array}{l}(P=\text { not signif- } \\
\text { icant })\end{array}$ & \\
\hline & & & Placebo: 7\% (37/498) & & \\
\hline Foda 1995 & NS & NS & $\begin{array}{l}\text { Cranberry: } 27 / 112 \\
\text { months }(24.1 \%) \\
\text { Placebo: } 34 / 117 \text { months } \\
(29 \%)\end{array}$ & NS & $\begin{array}{l}\text { Outcome was months with posi- } \\
\text { tive/significant culture but no UTI } \\
\text { symptoms }\end{array}$ \\
\hline $\begin{array}{l}\text { Linsenmeyer } \\
2004\end{array}$ & NS & NS & NS & NS & $\begin{array}{l}\text { The authors report that, 'We } \\
\text { failed to find a statistically sig- } \\
\text { nificant treatment effect for the } \\
\text { cranberry tablets beyond the } \\
\text { placebo effect when evaluating } \\
\text { urinary bacterial count ( } \mathrm{t} 20= \\
-0.05, \mathrm{P}=0.96 \text { ), urinary WBC (t20 } \\
=1.14, \mathrm{P}=0.27 \text { ), or urinary bacte- } \\
\text { rial and } \mathrm{WBC} \text { in combination (t } 20 \\
=1.14, \mathrm{P}=0.27 \text { )" }\end{array}$ \\
\hline \multirow[t]{2}{*}{ Wing 2008} & N/A & $\mathrm{N} / \mathrm{A}$ & $\begin{array}{l}\text { Cranberry, } 1 \text { dose: } 5 / 67 \\
\text { Cranberry } 2-3 \text { doses: } 2 / 58\end{array}$ & NS & $\begin{array}{l}\text { This data are for asymptomatic } \\
\text { UTI specifically }\end{array}$ \\
\hline & & & Placebo; $7 / 63$ & & \\
\hline \multirow[t]{2}{*}{ Hess 2008} & NS & NS & $\begin{array}{l}\text { Cranberry: } 31 \text { positive } \\
\text { culture episodes }\end{array}$ & $P=0.52$ & $\begin{array}{l}\text { This study reported symptomatic } \\
\text { and positive culture results }\end{array}$ \\
\hline & & & $\begin{array}{l}\text { Placebo: } 37 \text { positive cul- } \\
\text { ture episodes }\end{array}$ & & \\
\hline \multirow{3}{*}{$\begin{array}{l}\text { PACS Study } \\
2008\end{array}$} & $\mathrm{~N} / \mathrm{A}$ & $\mathrm{N} / \mathrm{A}$ & Cranberry, 1 dose: 13/20 & NS & \\
\hline & & & Cranberry, 2 doses: $14 / 19$ & & \\
\hline & & & No treatment: $12 / 17$ & & \\
\hline Uberos 2010 & $\mathrm{~N} / \mathrm{A}$ & $\mathrm{N} / \mathrm{A}$ & $\begin{array}{l}\text { Cranberry: } 8 / 23 \\
\text { Antibiotic: } 15 / 28\end{array}$ & NS & $\begin{array}{l}\text { In this report (abstract only) it } \\
\text { isn't clear if the repeat UTI was } \\
\text { symptomatic or a positive culture } \\
\text { result }\end{array}$ \\
\hline
\end{tabular}

N/A - not applicable; NS - not stated 
Table 4. Symptomatic UTIs

\begin{tabular}{|c|c|c|c|c|c|}
\hline Study name & $\begin{array}{l}\text { Pre cross- } \\
\text { over }\end{array}$ & $P$ value & End of study data & $P$ value & Notes \\
\hline \multirow[t]{2}{*}{ Schlager 1999} & NS & NS & Cranberry: 3 UTIs in 2 children & \multirow[t]{2}{*}{ NS } & \\
\hline & & & Placebo: 3 UTIs in 3 children & & \\
\hline \multirow[t]{2}{*}{ Avorn 1994} & $\mathrm{~N} / \mathrm{A}$ & $\mathrm{N} / \mathrm{A}$ & Cranberry: 20/473 (4\%) & \multirow{2}{*}{$\begin{array}{l}\text { Not significant } \\
\text { (P value NS) }\end{array}$} & \multirow[t]{2}{*}{ Denominator unclear } \\
\hline & & & Placebo: $37 / 498(7 \%)$ & & \\
\hline \multirow[t]{2}{*}{ Walker 1997} & \multirow[t]{2}{*}{ NS } & \multirow[t]{2}{*}{ NS } & & \multirow[t]{2}{*}{$P<0.05$} & $\begin{array}{l}\text { Whilst taking cranberry cap- } \\
\text { sules as opposed to place- }\end{array}$ \\
\hline & & & Placebo: 15 UTIs & & $\begin{array}{l}\text { bo, } 7 / 10 \text { subjects exhibited } \\
\text { fewer UTIs, } 2 \text { subjects ex- } \\
\text { hibited the same number of } \\
\text { UTIs, and } 1 \text { subject experi- } \\
\text { enced } 1 \text { more UTI. }\end{array}$ \\
\hline \multirow[t]{2}{*}{ Foda 1995} & \multirow[t]{2}{*}{ NS } & \multirow[t]{2}{*}{ NS } & $\begin{array}{l}\text { Cranberry: } 19 / 112 \text { months } \\
(17 \%)\end{array}$ & \multirow[t]{2}{*}{ NS } & \multirow[t]{2}{*}{$\begin{array}{l}\text { Months with positive/signif- } \\
\text { icant culture and UTI symp- } \\
\text { toms }\end{array}$} \\
\hline & & & $\begin{array}{l}\text { Placebo: } 20 / 117 \text { months } \\
(17.1 \%)\end{array}$ & & \\
\hline
\end{tabular}

\begin{tabular}{|c|c|c|c|c|c|}
\hline $\begin{array}{l}\text { Haverkorn } \\
1994\end{array}$ & NS & & & & No details provided \\
\hline Lee 2007 & $\mathrm{~N} / \mathrm{A}$ & N/A & $\begin{array}{l}\text { Cranberry: } 67 / 153 \\
\text { Cranberry placebo: } 71 / 152 \\
\text { Methenamine hippurate: } \\
67 / 150 \\
\text { Methenamine hippurate place- } \\
\text { bo: } 71 / 55\end{array}$ & $\begin{array}{l}\text { Hazard ra- } \\
\text { tio cranberry } \\
0.93(95 \% \mathrm{Cl} \\
0.66-1.29)\end{array}$ & \\
\hline Wing 2008 & $\mathrm{~N} / \mathrm{A}$ & N/A & $\begin{array}{l}\text { Cranberry } 1 \text { dose: } 2 / 67 \\
\text { Cranberry } 2-3 \text { doses: } 2 / 58 \\
\text { Placebo: } 0 / 63\end{array}$ & NS & $\begin{array}{l}\text { This study reported symp- } \\
\text { tomatic UTI and positive } \\
\text { culture results, these results } \\
\text { are symptomatic UTI }\end{array}$ \\
\hline Hess 2008 & $\begin{array}{l}\text { Pre-trial: } 1.3 \\
\text { UTIs/ per- } \\
\text { son/y }\end{array}$ & NS & $\begin{array}{l}\text { During the cranberry period, } \\
6 \text { participants had } 7 \text { UTI, com- } \\
\text { pared with } 16 \text { subjects and } 21 \\
\text { UTI in the placebo period. } \\
\text { The frequency of UTI was re- } \\
\text { duced to } 0.3 \text { UTI/y vs } 1.0 \text { UTI/y } \\
\text { while receiving placebo. }\end{array}$ & $P<0.05$ & $\begin{array}{l}\text { This study reported symp- } \\
\text { tomatic UTI and positive } \\
\text { culture results, these results } \\
\text { are symptomatic UTI }\end{array}$ \\
\hline Ferrara 2009 & $\mathrm{~N} / \mathrm{A}$ & N/A & $\begin{array}{l}\text { Cranberry: 5/27 } \\
\text { Lactobacillus: } 11 / 26 \\
\text { No treatment: } 18 / 27\end{array}$ & $\begin{array}{l}\mathrm{P}<0.5 \text { cran- } \\
\text { berry vs Lac- } \\
\text { tobacillus } \\
\text { groups and } \\
\text { control }\end{array}$ & \\
\hline
\end{tabular}


Table 4. Symptomatic UTIs

\begin{tabular}{|c|c|c|c|c|c|}
\hline McMurdo 2009 & N/A & N/A & $\begin{array}{l}\text { Cranberry: 25/69 } \\
\text { Antibiotic: } 14 / 68\end{array}$ & $P=0.084$ & $\begin{array}{l}\text { Only } 19 / 39 \text { symptomatic } \\
\text { UTIs had positive culture re- } \\
\text { sults }\end{array}$ \\
\hline Salo 2010 & $\mathrm{~N} / \mathrm{A}$ & $\mathrm{N} / \mathrm{A}$ & $\begin{array}{l}\text { Cranberry: } 20 / 125 \\
\text { Placebo: } 28 / 127\end{array}$ & $P=0.21$ & $\begin{array}{l}\text { This data are during } 12 \\
\text { months but participants } \\
\text { were only treated for } 6 \\
\text { months. On-treatment data } \\
\text { are not reported }\end{array}$ \\
\hline $\begin{array}{l}\text { Barbosa-Ces- } \\
\text { nik } 2011\end{array}$ & N/A & N/A & $\begin{array}{l}\text { Cranberry: 31/155 } \\
\text { Placebo: } 23 / 164\end{array}$ & $P=0.21$ & \\
\hline $\begin{array}{l}\text { NAPRUTI } \\
\text { Study } 2011 \text { I }\end{array}$ & N/A & N/A & $\begin{array}{l}\text { Cranberry: } 78.2 \% \\
\text { Antibiotic: } 71.1 \%\end{array}$ & $P=0.03$ & $\begin{array}{l}\text { These UTI results are for } \\
\text { clinical UTI not necessari- } \\
\text { ly microbiologically deter- } \\
\text { mined }\end{array}$ \\
\hline $\begin{array}{l}\text { Sengupta } \\
2011\end{array}$ & $\mathrm{~N} / \mathrm{A}$ & $\mathrm{N} / \mathrm{A}$ & $\begin{array}{l}\text { Cranberry }(500 \mathrm{mg} / \mathrm{d}): 2 / 21 \\
\text { Cranberry }(1000 \mathrm{mg} / \mathrm{d}): 2 / 23 \\
\text { No treatment: } 4 / 12\end{array}$ & NS & \\
\hline Cowan 2012 & N/A & N/A & $\begin{array}{l}\text { Cranberry: } 26 / 59 \\
\text { Placebo: } 23 / 59\end{array}$ & $P=0.28$ & $\begin{array}{l}\text { This data are symptomatic } \\
\text { UTI not necessarily culture } \\
\text { proven }\end{array}$ \\
\hline
\end{tabular}

N/A - not applicable; NS - not stated

APPENDICES

Appendix 1. Electronic search strategies

\begin{tabular}{ll}
\hline Database & Search terms used \\
\hline CENTRAL & 1. MeSH descriptor Beverages, this term only in MeSH products \\
2. MeSH descriptor Fruit, this term only in MeSH products \\
3. cranberr* in All Fields in all products \\
4. fruit near beverage* in All Fields in all products \\
5. fruit near drink* in All Fields in all products \\
6. fruit near juice* in All Fields in all products \\
7. MeSH descriptor Phytotherapy, this term only in MeSH products \\
8. MeSH descriptor Vaccinium macrocarpon, this term only in MeSH products \\
9. MeSH descriptor Vaccinium vitis-idaea, this term only in MeSH products \\
10.vaccinium oxycoccus in All Fields in all products \\
11.vaccinium vitis-idaea in All Fields in all products \\
12.(\#1 OR \#2 OR \#3 OR \#4 OR \#5 OR \#6 OR \#7 OR \#8 OR \#9 OR \#10 OR \#11) \\
13.MeSH descriptor Urinary Tract Infections explode all trees in MeSH products \\
14.MeSH descriptor Pyelonephritis explode all trees in MeSH products \\
15.MeSH descriptor Cystitis explode all trees in MeSH products
\end{tabular}


(Continued)
16.uti in All Fields in all products
17.bacter ${ }^{\star}$ in All Fields in all products
18.cystitis in All Fields in all products
19.pyelonephritis in All Fields in all products
20.MeSH descriptor Urine, this term only in MeSH products
21. (urin* near infect*) in All Fields in all products
22.(\#13 OR \#14 OR \#15 OR \#16 OR \#17 OR \#18 OR \#19 OR \#20 OR \#21)
23. (\#12 AND \#22)

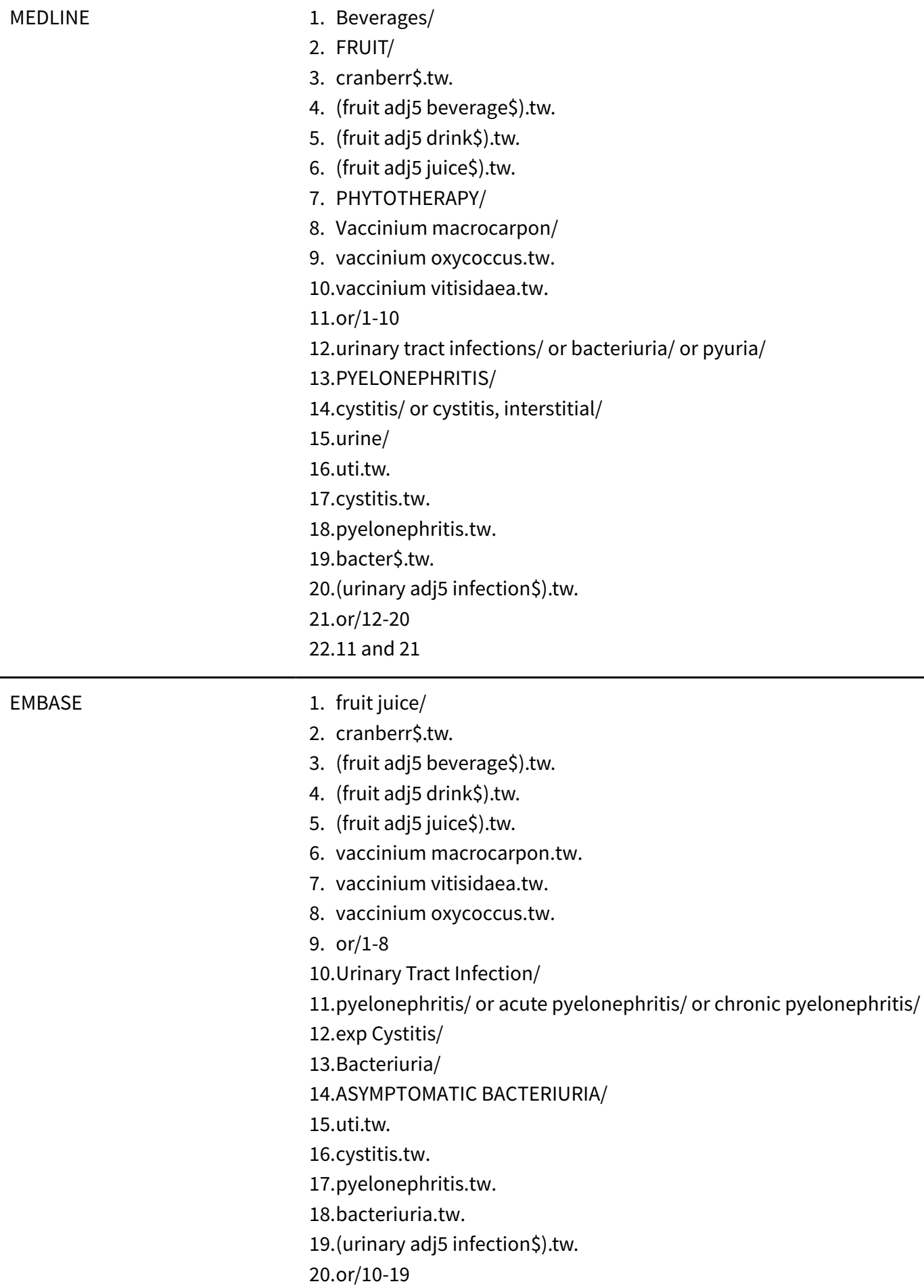

MEDLINE

1. Beverages/

2. FRUIT/

3. cranberr\$.tw.

4. (fruit adj5 beverage\$).tw.

5. (fruit adj5 drink\$).tw.

6. (fruit adj5 juice\$).tw.

7. PHYTOTHERAPY/

8. Vaccinium macrocarpon/

9. vaccinium oxycoccus.tw.

10.vaccinium vitisidaea.tw.

11.or/1-10

12.urinary tract infections/ or bacteriuria/ or pyuria/

13.PYELONEPHRITIS/

14.cystitis/ or cystitis, interstitial/

15.urine/

16.uti.tw.

17.cystitis.tw.

18. pyelonephritis.tw.

19.bacter\$.tw.

20.(urinary adj5 infection\$).tw.

21.or/12-20

22.11 and 21

1. fruit juice/

2. cranberr\$.tw.

3. (fruit adj5 beverage\$).tw.

4. (fruit adj5 drink\$).tw.

5. (fruit adj5 juice\$).tw.

6. vaccinium macrocarpon.tw.

7. vaccinium vitisidaea.tw.

8. vaccinium oxycoccus.tw.

9. or $/ 1-8$

10.Urinary Tract Infection/

11.pyelonephritis/ or acute pyelonephritis/or chronic pyelonephritis/

12.exp Cystitis/

13. Bacteriuria/

14.ASYMPTOMATIC BACTERIURIA/

15.uti.tw.

16.cystitis.tw.

17. pyelonephritis.tw.

18. bacteriuria.tw.

19.(urinary adj5 infection\$).tw.

20.or/10-19 


\section{Appendix 2. Risk of bias assessment tool}

\begin{tabular}{ll}
\hline Potential source of bias & Assessment criteria \\
\hline $\begin{array}{l}\text { Random sequence genera- } \\
\text { tion }\end{array}$ & $\begin{array}{l}\text { Low risk of bias: Random number table; computer random number generator; coin tossing; shuf- } \\
\text { fling cards or envelopes; throwing dice; drawing of lots; minimization (minimization may be imple- } \\
\text { mented without a random element, and this is considered to be equivalent to being random). }\end{array}$ \\
\cline { 2 - 2 } $\begin{array}{l}\text { Selection bias (biased alloca- } \\
\text { tion to interventions) due to } \\
\text { inadequate generation of a } \\
\text { randomised sequence }\end{array}$ & $\begin{array}{l}\text { High risk of bias: Sequence generated by odd or even date of birth; date (or day) of admission; se- } \\
\text { quence generated by hospital or clinic record number; allocation by judgement of the clinician; by } \\
\text { preference of the participant; based on the results of a laboratory test or a series of tests; by avail- } \\
\text { ability of the intervention. }\end{array}$
\end{tabular}

Unclear: Insufficient information about the sequence generation process to permit judgement.

\section{Allocation concealment}

Selection bias (biased allocation to interventions) due to inadequate concealment of allocations prior to assignment
Low risk of bias: Randomisation method described that would not allow investigator/participant to know or influence intervention group before eligible participant entered in the study (e.g. central allocation, including telephone, web-based, and pharmacy-controlled, randomisation; sequentially numbered drug containers of identical appearance; sequentially numbered, opaque, sealed envelopes).

High risk of bias: Using an open random allocation schedule (e.g. a list of random numbers); assignment envelopes were used without appropriate safeguards (e.g. if envelopes were unsealed or non-opaque or not sequentially numbered); alternation or rotation; date of birth; case record number; any other explicitly unconcealed procedure.

Unclear: Randomisation stated but no information on method used is available.

\section{Blinding of participants and personnel}

Performance bias due to knowledge of the allocated interventions by participants and personnel during the study
Low risk of bias: No blinding or incomplete blinding, but the review authors judge that the outcome is not likely to be influenced by lack of blinding; blinding of participants and key study personnel ensured, and unlikely that the blinding could have been broken.

High risk of bias: No blinding or incomplete blinding, and the outcome is likely to be influenced by lack of blinding; blinding of key study participants and personnel attempted, but likely that the blinding could have been broken, and the outcome is likely to be influenced by lack of blinding.

\section{Blinding of outcome assess- ment}

Detection bias due to knowledge of the allocated interventions by outcome assessors.
Unclear: Insufficient information to permit judgement

Low risk of bias: No blinding of outcome assessment, but the review authors judge that the outcome measurement is not likely to be influenced by lack of blinding; blinding of outcome assessment ensured, and unlikely that the blinding could have been broken.

High risk of bias: No blinding of outcome assessment, and the outcome measurement is likely to be influenced by lack of blinding; blinding of outcome assessment, but likely that the blinding could have been broken, and the outcome measurement is likely to be influenced by lack of blinding.

Unclear: Insufficient information to permit judgement
Low risk of bias: No missing outcome data; reasons for missing outcome data unlikely to be related to true outcome (for survival data, censoring unlikely to be introducing bias); missing outcome data balanced in numbers across intervention groups, with similar reasons for missing data across groups; for dichotomous outcome data, the proportion of missing outcomes compared with observed event risk not enough to have a clinically relevant impact on the intervention effect esti- 
mate; for continuous outcome data, plausible effect size (difference in means or standardized difference in means) among missing outcomes not enough to have a clinically relevant impact on observed effect size; missing data have been imputed using appropriate methods.

High risk of bias: Reason for missing outcome data likely to be related to true outcome, with either imbalance in numbers or reasons for missing data across intervention groups; for dichotomous outcome data, the proportion of missing outcomes compared with observed event risk enough to induce clinically relevant bias in intervention effect estimate; for continuous outcome data, plausible effect size (difference in means or standardized difference in means) among missing outcomes enough to induce clinically relevant bias in observed effect size; 'as-treated' analysis done with substantial departure of the intervention received from that assigned at randomisation; potentially inappropriate application of simple imputation.

Unclear: Insufficient information to permit judgement

\section{Selective reporting}

Reporting bias due to selective outcome reporting
Low risk of bias: The study protocol is available and all of the study's pre-specified (primary and secondary) outcomes that are of interest in the review have been reported in the pre-specified way; the study protocol is not available but it is clear that the published reports include all expected outcomes, including those that were pre-specified (convincing text of this nature may be uncommon).

High risk of bias: Not all of the study's pre-specified primary outcomes have been reported; one or more primary outcomes is reported using measurements, analysis methods or subsets of the data (e.g. subscales) that were not pre-specified; one or more reported primary outcomes were not prespecified (unless clear justification for their reporting is provided, such as an unexpected adverse effect); one or more outcomes of interest in the review are reported incompletely so that they cannot be entered in a meta-analysis; the study report fails to include results for a key outcome that would be expected to have been reported for such a study.

Unclear: Insufficient information to permit judgement

\section{Other bias}

Low risk of bias: The study appears to be free of other sources of bias.

Bias due to problems not covered elsewhere in the table
High risk of bias: Had a potential source of bias related to the specific study design used; stopped early due to some data-dependent process (including a formal-stopping rule); had extreme baseline imbalance; has been claimed to have been fraudulent; had some other problem.

Unclear: Insufficient information to assess whether an important risk of bias exists; insufficient rationale or evidence that an identified problem will introduce bias.

WHAT'S NEW

\begin{tabular}{lll}
\hline Date & Event & Description \\
\hline 16 June 2014 & Amended & Minor grammatical correction made \\
\hline
\end{tabular}

\section{H I S T ORY}

Protocol first published: Issue 2, 1998

Review first published: Issue 2, 1998 


\begin{tabular}{lll}
\hline Date & Event & Description \\
\hline 2 April 2013 & Amended & Minor spelling corrections made throughout \\
\hline 14 September 2012 & $\begin{array}{l}\text { New citation required and conclusions } \\
\text { have changed }\end{array}$ & $\begin{array}{l}\text { Updated the review in 2012 with 14 new studies. Conclusions } \\
\text { have changed to say that the evidence suggests that cranberry } \\
\text { products are not effective in preventing UTIs. }\end{array}$ \\
\hline 13 August 2009 & Amended & Contact details updated. \\
\hline 13 May 2009 & Amended & Contact details updated. \\
\hline 23 September 2008 & Amended & Converted to new review format. \\
\hline 10 September 2007 & $\begin{array}{l}\text { New citation required and conclusions } \\
\text { have changed }\end{array}$ & \begin{tabular}{l} 
Substantive amendment \\
\hline
\end{tabular} \\
\hline
\end{tabular}

\section{CONTRIBUTIONS OF AUTHORS}

- RJ: study design, search strategy, study selection, quality assessment, data extraction, data analysis, writing of review, updating of review.

- JCC: study design, writing of review, updating review

- GW: update search, study selection, quality assessment, data extraction, writing

\section{DECLARATIONS OF INTEREST}

None known

\section{SOURCES OF SUPPORT}

\section{Internal sources}

- No sources of support supplied

\section{External sources}

- Nuffield Trust, UK.

- NHS - NIHR, UK.

Funding to update the latest version of the review

\section{DIFFERENCES BETWEEN PROTOCOL AND REVIEW}

Risk of bias assessment tool has replaced quality assessment checklist.

\section{INDEX TERMS}

\section{Medical Subject Headings (MeSH)}

${ }^{\star}$ Beverages; *Vaccinium macrocarpon; Capsules; Cross-Over Studies; Phytotherapy [ ${ }^{\star}$ methods]; Plant Preparations ["therapeutic use]; Randomized Controlled Trials as Topic; Recurrence; Sex Factors; Tablets; Urinary Tract Infections [ ${ }^{\star}$ prevention \& control]

\section{MeSH check words}

Female; Humans; Male 